\author{
UNIVERSIDADE DE SÃO PAULO \\ FACULDADE DE FILOSOFIA, LETRAS E CIÊNCIAS HUMANAS \\ DEPARTAMENTO DE HISTÓRIA \\ PROGRAMA DE PÓS-GRADUAÇÃO EM HISTÓRIA SOCIAL
}

ANGELO ANTONIO GRECO

O Ensino Religioso nas escolas públicas paulistas

$(1930-1945)$

São Paulo

2016 


\section{O ensino religioso nas escolas públicas paulistas}

(1930 - 1945)

Tese apresentada ao programa de Pós - Graduação em História Social da Faculdade de Filosofia, Letras e Ciências Humanas da Universidade de São Paulo, para obtenção do título de Doutor em História Social.

Área de Concentração: História Social

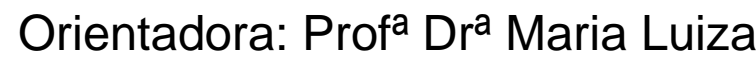
Marcílio 
Autorizo a reprodução e divulgação total ou parcial deste trabalho, por qualquer meio convencional ou eletrônico, para fins de estudo e pesquisa, desde que citada a fonte.

Catalogação na Publicação

Serviço de Biblioteca e Documentação

Faculdade de Filosofia, Letras e Ciências Humanas da Universidade de São Paulo

G791e Greco, Angelo Antonio

O Ensino Religioso nas escolas públicas paulistas (1930-1945) / Angelo Antonio Greco ; orientadora Maria Luiza Marcílio. - São Paulo, 2016.

$158 \mathrm{f}$.

Tese (Doutorado) - Faculdade de Filosofia, Letras e Ciências Humanas da Universidade de São Paulo. Departamento de História. Área de concentração: História Social.

1. Ensino Religioso. 2. Igreja Católica. 3. Escola Pública. 4. Era Vargas. 5. São Paulo. I. Marcílio, Maria Luiza, orient. II. Título. 


\section{Folha de Aprovação}

Greco, Angelo Antonio. O Ensino Religioso nas escolas públicas paulistas (19301945). Tese (Doutorado em História) - Faculdade de Filosofia, Letras e Ciências Humanas, USP: São Paulo, 2016. Tese apresentada ao programa de Pós Graduação em História Social da Faculdade de Filosofia, Letras e Ciências Humanas da Universidade de São Paulo, para obtenção do título de Doutor em História Social.

Aprovado em:

\section{Banca Examinadora}

Prof. Dr.

Julgamento:

Prof. Dr.

Julgamento:

Prof. Dr.

Julgamento:

Prof. Dr.

Julgamento:

Prof. Dr. Instituição:

Julgamento:
Instituição:

Assinatura:

Instituição:

Assinatura:

Instituição:

Assinatura:

Instituição:

Assinatura:

Assinatura 
Para o meu pai, Nicola (in memoriam), Minha mãe, Nely, Minha irmã Alessandra e Para Paula, com amor. 


\section{Agradecimentos}

Em primeiro lugar, agradeço a Deus pela força que me dá todos os dias, permitindo a minha chegada até aqui com equilíbrio. Agradeço à minha orientadora Maria Luiza Marcílio por me aceitar como aluno, pelos seus ensinamentos e pela enorme paciência que teve ao longo deste percurso. Aos funcionários do Centro de Memória da Escola Caetano de Campos, onde fiz as primeiras pesquisas. Ao Jair Mongelli Júnior, do Arquivo da Cúria Metropolitana de São Paulo, pela preciosa ajuda e dicas durante a pesquisa. Ao professor Dr. Bruno Bontempi Júnior e ao professor Dr. Carlos de Almeida Prado Bacellar, que, no Exame de Qualificação, deram sugestões muito importantes para o direcionamento da Tese. Ao programa Bolsa Mestrado/Doutorado do Governo do Estado de São Paulo que me concedeu incentivo financeiro durante parte do período de pesquisa. Agradeço à Marizilda e à Sueli, responsáveis pelo Programa na Diretoria de Ensino Centro Sul de São Paulo. À diretora da Escola Estadual Jacques Maritain, Leila Marise Garcia Salles, pela ajuda durante o período. Aos meus amigos Fernando Antonio Alves da Costa e Fernando Rodrigues de Mendonça pela força, amizade e troca de ideias.

Logo após o Exame de Qualificação, ocorreu o falecimento do meu pai, Nicola, o que me entristeceu e mudou bastante os rumos da minha vida. Ele gostaria de ter visto a conclusão deste Doutorado. Agradeço muito a ele por tudo. À minha mãe, Nely, exemplo de vida, humildade e simplicidade, agradeço, com muito amor. À minha irmã, Alessandra, tão doce e que dá sentido à minha vida. $E$ à Eugenia Paula, pessoa muito especial, que me ajudou, me deu ânimo e que está sempre ao meu lado, fazendo com que eu fique mais feliz. 
Greco, Angelo Antonio. O Ensino Religioso nas escolas públicas paulistas (1930-1945). Tese (Doutorado em História) - Faculdade de Filosofia, Letras e Ciências Humanas, USP: São Paulo, 2016.

\section{Resumo}

Após a Proclamação da República no Brasil, em 1889, houve a separação entre Igreja Católica e política, sendo que o Ensino Religioso não podia ser aplicado nas escolas públicas, apenas em particulares. Nos anos 1920, a Igreja Católica se reaproximou dos políticos. Essa reconciliação ficou mais evidente depois da Revolução de 1930, quando Getúlio Vargas chegou ao poder e, alguns meses depois, publicou o decreto que tornava o Ensino Religioso facultativo nas escolas públicas, em abril de 1931. Esta Tese mostra como o Ensino Religioso foi instrumento de fortalecimento católico, reconquistando espaços perdidos na República Velha, num movimento que tinha como contexto as ações de romanização, de ultramontanismo e da Ação Católica, fundada pelo papa Pio XI. O decreto de Vargas foi feito claramente em benefício dos católicos e, anos depois, foi incorporado na Constituição de 1934, por pressão da Liga Eleitoral Católica. O Ensino Religioso era considerado como obra principal pelos católicos e houve grande organização na Arquidiocese de São Paulo, com fiscais e delegadas fazendo relatórios do seu andamento nas escolas. Para melhor discussão do assunto, foi escolhida a análise das escolas públicas, pois houve a inserção do ensino católico num ambiente laico, com alunos de outras confissões religiosas.

Palavras-chave: Ensino Religioso, Igreja Católica, Escola Pública, Era Vargas, São Paulo. 
Greco, Angelo Antonio. Religious Education in São Paulo public schools (1930-1945). Tese (Doutorado em História) - Faculdade de Filosofia, Letras e Ciências Humanas, USP: São Paulo, 2016.

\begin{abstract}
After the Republic Proclamation in Brazil in 1889, there was a separation between the Catholic Church and politics, and Religious Education could not be applied in public schools, only in private. In the 1920s, the Catholic Church reconnected to the politicians. This reconciliation was more evident after the 1930 Revolution, when Getulio Vargas came to power and a few months later, he published the decree that made the optional religious education in public schools, in April 1931. This thesis shows how the Religious Education was instrumental Catholic strengthening, regaining lost spaces in the Old Republic, a movement that had as context the actions of romanization of ultramontanism and Catholic Action, founded by Pope Pius XI. Vargas decree was clearly done for the benefit of Catholics and, years later, was incorporated in the 1934 Constitution, under pressure from the Catholic Electoral League. Religious Education was considered as a major work by Catholics and there was a great organization in the Archdiocese of São Paulo, with inspectors and delegates making their progress reports in schools. To further discussion of the subject, the analysis of public schools was chosen because there was the inclusion of Catholic teaching in a secular environment with students from other religious denominations.
\end{abstract}

Keywords: Religious Education, Catholic Church, Public School, Vargas Age, São Paulo. 


\section{Lista de Figuras}

Figura 1: Organograma da Diretoria

Arquidiocesana do Ensino Religioso

.88

Figura 2 - Formatura da Primeira

Turma de Catequistas do Curso de

Religião na Cúria Metropolitana.

Figura 3: Questionário da Diretoria

Arquidiocesana do Ensino Religioso nas escolas

136

\section{Lista de tabelas}

Tabela 1: Dados das escolas visitadas

pela fiscalização do Ensino religioso 1941

Tabela 2: Dados das escolas visitadas

pela fiscalização do Ensino religioso 1942

Tabela 3: Dados das escolas visitadas

pela fiscalização do Ensino religioso 1943.

Tabela 4: Dados das escolas visitadas

pela fiscalização do Ensino religioso 1944

Tabela 5: Dados das escolas visitadas

pela fiscalização do Ensino religioso 1945 


\section{Sumário}

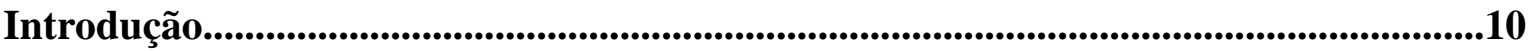

Capítulo 1: A Presença católica na

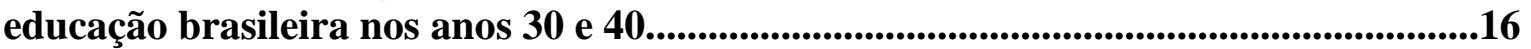

Capítulo 2: A luta política pelo Ensino

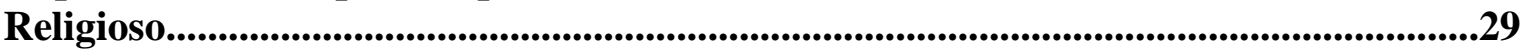

Capítulo 3: Organização do Ensino

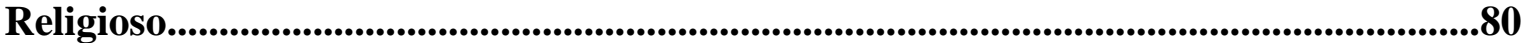

Capítulo 4: Fiscalização do Ensino

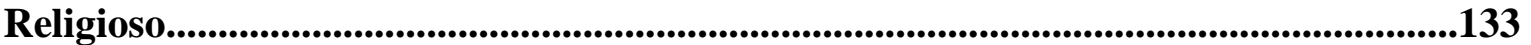

Considerações

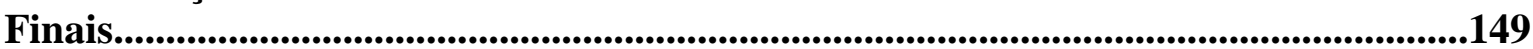

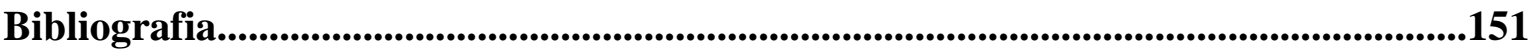




\section{Introdução}

A busca pelo Ensino religioso em São Paulo teve dois aspectos: um foi o da romanização e ultramontanismo, que vinha desde o século XIX. Outro foi a tentativa de influência católica na educação do povo, tanto nas escolas católicas particulares quanto nas escolas públicas. A proposta deste trabalho é apresentar a influência que a Igreja Católica teve na escola pública da cidade de São Paulo e adjacências, vez ou outra citando algum município do Estado paulista como referência ou meio de comparação. São Paulo foi escolhida por faltarem estudos referentes à implantação do Ensino religioso nessa região, que despontava com grande crescimento econômico. Recusa-se aqui a teoria que tem São Paulo como carro-chefe da Nação, locomotiva, ou as teses que apontam os acontecimentos de São Paulo como modelo para todo o país. Muitas vezes, São Paulo serviu como exemplo de atraso e reacionarismo, mas na maioria das vezes, de conservadorismo, ao menos num viés político.

No entanto, é bastante interessante a forma como a Igreja Católica interveio na escola pública, especialmente através do Ensino Religioso, o que fazia parte de um grande esquema de atuação da instituição no Brasil. São Paulo crescia muito em termos populacionais, em indústrias, em atividades econômicas. Em 1920, a cidade possuía 579.033 pessoas. Já em 1940 contava com 1.326.261 e, em 1950, 2.198.096. O número de escolas também cresceu. Muitas foram fundadas desde o século XIX, etc. (Dados do IBGE).

A escola pública foi escolhida na pesquisa por proporcionar melhor discussão acerca da intervenção religiosa, visto que havia um intenso debate sobre educação religiosa, estado laico, escola sem religião, possibilidade de guerra entre religiões na escola, etc. A escola pública é o ambiente da diversidade, da presença de classes sociais diferentes e de crenças distintas e por isso favorece a debate religioso. 
É possível recusar algumas categorias presentes no senso comum ou generalizações sobre a educação, que afirmam ser a escola dos anos 30 e 40, uma escola elitizada em comparação com a educação dos anos posteriores. E, devido a uma presença diversa na escola pública, é possível haver melhor discussão do que no ambiente da escola particular católica, uma instituição que possui óbvia intervenção doutrinal.

A Igreja Católica, em todo o mundo, sempre procurou impedir o ensino laico e o chamado modelo napoleônico de educação, ou seja, escolas públicas em todo o território, sem professar uma doutrina específica.

No Brasil, não foi diferente. Muitos discursos ao longo do século $X X$ enfatizavam a liberdade de ensino privado e público, já que muitas (a maioria) das escolas particulares pertenciam a irmandades católicas. Foi uma proposta da Constituição de 1891, o Estado laico, a proibição do ensino religioso nas escolas públicas, mas a possibilidade do ensino privado. A $1^{\text {a }}$ Carta Magna da era republicana brasileira não apresentava grandes preocupações com a educação, apenas separando Estado e religião e deixando a escola pública fora da área de influência das religiões. No entanto, surgiram, no Estado de São Paulo, diversos Grupos Escolares e (Escolas Centrais) no início do mesmo período. Uma das premissas da Nova Constituição era o voto permitido apenas a alfabetizados. Daí a abertura de várias escolas nas capitais e no interior.

A Igreja Católica, desde o papado de Leão XIII (1879-1903) teve a proposta ultramontana de maior penetração nas sociedades, nos países. Essa proposta é também conhecida como romanização. No século XIX, documento como a bula papal Syllabus e a Kulturkampf na Alemanha problematizavam a questão da laicidade e as relações entre Igreja, Estado e outra religiões. A Syllabus Errorum foi promulgada em 1864 pelo Papa Pio IX e possuía 80 pontos considerados errados pela autoridade da Igreja. Na Alemanha, foi idealizada a política da Kulturkampf, por Otto Von Bismark, uma forma do Estado delimitar a influência católica devido a razões nacionalistas. 
A partir dos anos 1920, houve uma aproximação entre Igreja e governo brasileiro. Logo após a Proclamação da República, o projeto militar-positivista foi vitorioso em um primeiro momento; muitas disputas ocorreram em torno do ideal republicano entre militares, republicanos moderados e monarquistas. Após a Guerra de Canudos e também o atentado ao presidente da República, Prudente de Morais, o projeto político dos republicanos ligados aos cafeicultores foi vitorioso. A Constituição, porém, não foi modificada e a influência católica na educação ficava barrada pela lei brasileira.

Os anos 1920, de acordo com vários autores, foram decisivos para transformações na sociedade brasileira. A organização política brasileira, as fraudes, a falta de educação e cultura foram seriamente questionadas e algumas movimentações foram decisivas para demonstrar a insatisfação de parte dos brasileiros. O movimento tenentista e a revolta dos 18 do Forte em Copacabana foram iniciais de uma série de movimentos que culminaram na Revolução de 1930. A Repressão aos 18 do Forte levou posteriormente à Revolução Paulista de 1924, já no governo de Artur Bernardes. A revolta, localizada na cidade de São Paulo foi também duramente reprimida pelo governo. Os articuladores da revolta uniram-se a outros combatentes no Paraná e formaram a Coluna Prestes, que, a partir de 1925, percorreu o Brasil do Nordeste ao Sul arregimentando forças para combater o coronelismo, a sociedade prioritariamente agrária e pleiteando uma educação que atingisse parcela maior da sociedade.

Outro movimento importante foi a Semana de Arte Moderna ocorrida em São Paulo, entre os dias 11 e 18 de fevereiro de 1922. Os artistas participantes da semana demonstraram a importância da cultura brasileira, fundamentada em costumes, princípios e linguagens nacionais, destacando, assim, a necessidade de se educar o povo brasileiro.

Nesse momento, a Igreja Católica começou a se reaproximar do poder, seguindo a orientação romana e as iniciativas da Ação Católica. Ocorreu o famoso encontro do Cardeal Arcoverde com Artur Bernardes, que visava apoio mútuo, já que a Igreja desejava maiores privilégios. No governo Artur Bernardes enfrentava dificuldades revoltas e Estado de sítio. 
Nesse período, a atuação do Cardeal Dom Sebastião Leme da Silveira Cintra teve grande destaque na expansão dos objetivos da Ação Católica no Brasil. Ele possuía um bom trânsito entre os políticos desde a sua nomeação como arcebispo de Olinda e Recife em 1916, quando lançou sua Carta Pastoral, passando pela sua nomeação como arcebispo titular de Pharsalus, arcebispocoadjutor do Rio de Janeiro, em 15 de março de 1921. De acordo com Henrique Cristiano José Matos o período de 1921 a 1942 pode ser chamado sem exagero de "A Igreja Dom Leme", passando o cardeal a adotar sem reservas a política de Pio XI que visava à restauração da ordem cristã. Em maio de 1922, havia sido fundado, no Rio, o Centro Dom Vital, com sua revista A Ordem.

Em uma carta para Dom Duarte Leopoldo, em 1922, Dom Leme indagava: "Viu V.Excia como N. Senhor escreve direito por linhas tortas? Em que foi parar o laicismo da República?" Dom Leme se referia a um episódio de um passeio no 'carro de Estado', ao lado de um chefe político, por entre alas do Exército, sendo aclamados ambos. "Ficou provado, segundo ele, que em certos momentos de perigo de morte ou de vaia, não há laicismo nem Constituição e o bispo serve para alguma coisa." "Centenas de avisos recebi de que o negócio era sério. Até granadas de mão havia. "E fui! E ta Eu!" Após citar alguns deboches de oposicionistas declara que ficou constatado o prestígio da Igreja, ficou derrotado o laicismo, abriu-se o precedente, manteve-se a ordem.

Dois meses depois, Dom Leme citou uma gripe que o tirou de um banquete do Presidente da República. "E por falar em Presidente da República, sabe V. Excia que o meu nome andou uma tarde inteira nos boatos que procuravam um candidato de conciliação entre Bernardes e Nilo? Um jornal houve que chegou a estampar a minha simpática figura com títulos e subtítulos: "O Candidato"

Em 1925, uma correspondência entre os dois prelados mostrava alguns boatos de "2 ou 3 bobos" que diziam estar D. Leme em perigo de ser Presidente da República. "Se bobos são os que dizem isso, mais bobos os que acreditam."

A carta do Padre Rosalvo Costa Rego a Dom Duarte Leopoldo tece muitos elogios a Dom Leme: "suas conferências quaresmais, na catedral, confirmaram- 
Ihe definitivamente a fama de erudito conferencista e orador sacro, que havia conquistado, sem favor, em São Paulo." "Fundou a Confederação Católica do Rio de Janeiro, base de todo o trabalho da Ação Católica. Chefe incomparável da Ação Católica Brasileira, lembra-nos Sua Eminência as velhas e clássicas figuras de bispo à antiga, no desassombro e intransigência com que defende os interesses espirituais da terra comum.

Tudo o que D. Leme fez, de acordo com o Pe Rosalvo Costa Rego, é digno de pouco brilho, ante a luta pela salvação da família, educação religiosa das gerações do futuro, assistência espiritual a quartéis e hospitais e o mais que se obteve na Constituição de 1934. e conclui: "Verdadeiro batismo da nova República, que já põe a brecha enorme que abrimos, no laicismo oficial, venha a ser a porta aberta para novas conquistas e maiores triunfos, no Reino de Cristo. (Carta do Padre Rosalvo Costa Rego a Dom Duarte Leopoldo em 15/5/1936).

É um indicativo da grande tentativa dos católicos de avançar sobre o muro de separação entre política e religião. O plano da Ação Católica era interferir na vida pública, formar um grupo de leigos católicos atuantes visando influenciar pessoas, fazer conversões, ampliando o espaço de atuação da Igreja na sociedade brasileira. Na época, não era percebido nos discursos, cartas ou documentos oficiais da Igreja nenhuma tentativa de diálogo com outras religiões, já consolidadas no Brasil, como o protestantismo e o espiritismo. Pelo contrário, a tentativa dos católicos era sempre confrontar forças e diminuir a influência dos outros grupos considerados rivais e empecilhos ao pleno desenvolvimento católico. A orientação na época era a de que a Igreja Católica era a única representante de Cristo e em condições de salvar a população. Essa noção é apresentada por Dom Leme em correspondência: "o mundo tem ainda 1.066 milhões de infiéis em cuja evangelização estão empenhados, na hora atual, 17 mil missionários, apenas. Daí o convite do Santo Padre a que no mundo inteiro se mobilize uma cruzada visando a colaboração de todos os católicos na obra missionária”. (Carta de D. Leme a D. Duarte Leopoldo. 21/09/1926).

Os marcos cronológicos da pesquisa são justificados pelos acontecimentos religiosos em torno da educação. Em 31/12/1929, o Papa Pio XI promulgou a 
Encíclica 'Divini Illius Magistri' sobre a Educação Cristã da Juventude. Uma rápida resposta foi observada no Brasil com a questão do Ensino religioso facultativo nas escolas públicas sendo proposta pelos setores católicos especialmente os ligados à Ação Católica. Optou-se por delimitar o estudo até o ano de 1945, quando acontece o fim do governo Vargas, que foi de certa forma um parceiro da Igreja Católica na questão do Ensino religioso. Nota-se a continuidade da oferta do Ensino Religioso, e da Inspetoria nas escolas públicas. Porém, novas relações são traçadas entre política e Igreja.

A Encíclica 'Divini Illius Magistri' foi escrita para jovens, educadores, pais e mães sobre vários problemas da educação cristã. Em meio a muitas discussões sobre teorias e métodos pedagógicos que se pretendiam infalíveis, e sem a presença religiosa, o Papa Pio XI atentou para o perigo da pedagogia sem Deus. 
Capítulo 1

A presença católica na educação paulista

dos anos 30 e 40 
A religiosidade no Brasil teve suas particularidades. De acordo com o Cardeal Dom Paulo Evaristo Arns, os padres que ensinavam eram poucos, apareciam de ano em ano, de tempos em tempos, não entendiam a cultura brasileira, nem a língua. O povo ouvia uma coisa e entendia outra. A família e os grupos é que conservavam costumes e formavam mentalidade, misturando-os com as pregações, normalmente moralistas, que ouviam. Apesar da existência da catequese, ela transmitia mais conceitos do que explicações da vida e não oferecia possibilidade de aprofundar o sentimento e as ideias mais importantes. Em muitas partes do Brasil apareciam movimentos religiosos não católicos para ocupar os espaços vazios e "perturbar a fé" e assim se confundiam santos católicos com divindades espíritas. ${ }^{1}$

Sempre se considerou a religiosidade uma força que une o povo. O Brasil de norte a sul não seria a mesma pátria se não fosse essa religiosidade, é o que afirma o Cardeal Arns. Porém, o povo descobriu um caminho fácil para expressar a fé por sinais e atos religiosos que não comprometessem com a vida. Sinais que dispensavam o esforço, pois possuíam mágica, o que acabou levando ao indiferentismo. ${ }^{2}$

Uma importante compreensão da relação política-Igreja é a de Scott Maiwaring. D. Sebastião Leme tinha precedentes, mas o modelo da neocristandade começou a se desenvolver a partir dos anos 1920, atingindo seu apogeu durante o primeiro governo de Getúlio Vargas, entre 1930 e 1945. A Igreja permaneceu conservadora, opondo-se à secularização e às outras religiões, pregando hierarquia e ordem. Insistiu num catolicismo vigoroso, que penetrasse nas principais instituições e nos governos, promovendo, dessa forma, práticas pastorais diferentes de períodos anteriores, conseguindo interesses indispensáveis da Igreja: a influência católica sobre o sistema educacional, a moralidade católica, o anticomunismo e o antiprotestantismo. Através do modelo da neocristandade, a Igreja revitalizou sua presença dentro da sociedade. Era uma forma de se lidar com a fragilidade da instituição sem modificar de maneira

\footnotetext{
${ }^{1}$ ARNS, Cardeal D. Paulo Evaristo. O Evangelho: Incomoda? Inquieta? Interessa? Sínodo da evangelização. São Paulo: Edições Loyola, 1975. p. 23.

${ }^{2}$ Ibid. p. 23-24.
} 
significativa a natureza conservadora da mesma. Por volta dos anos 30 , segundo o autor, a instituição havia revertido sua decadência. ${ }^{3}$

O Vaticano encorajou os esforços da Igreja brasileira para fortalecer a presença da Igreja na sociedade, especialmente durante o papado de Pio XI (1922-1939), cuja visão da eclesiástica e política aproximava-se de Dom Sebastião Leme. Sob Pio XI, os movimentos da Ação Católica tornaram-se peçaschave dentro da Igreja. Pio XI julgava os partidos políticos como sendo demasiadamente divisionistas, mas de qualquer forma, tentava alianças com 0 Estado para defender interesses católicos. ${ }^{4}$

O autor enfatiza a relação da Igreja Católica com Getúlio Vargas, afirmando que a maioria dos bispos, padres e leigos apoiava seu governo, não só por causa dos privilégios que recebera, mas também devido à afinidade política. A ênfase que a Igreja atribuía à ordem, ao nacionalismo, ao patriotismo e ao anticomunismo coincidia com a orientação de Vargas. Clérigos destacados acreditavam que a legislação de Vargas realizava a doutrina social da Igreja e que o Estado Novo conseguia superar os males do liberalismo e do comunismo. ${ }^{5}$

A remessa ao patriotismo é fato quando se verifica as correspondências entre $\mathrm{D}$. Leme e D. Duarte Leopoldo. Há muitas menções à pátria e à nação. Em um discurso que D. Leme faria no Congresso Eucarístico de 1942 em São Paulo, escreve:

"É sempre com emoção que entro em contato com as forças armadas do Brasil. São elas que defendem o território da pátria, defendem nossa honra, as nossas famílias, a nossa liberdade, a nossa bandeira. Brasileiro, é comovido que estendo a mão ao soldado do Brasil. Sacerdote, eu faço com mais razão ainda. Soldados de Cristo e soldados da Pátria, pertencemos a duas classes que impõe disciplina moral, espírito de renúncia e de sacrifício.

(...) Em geral, os inimigos da batina são os mesmos inimigos da farda. Não querem a disciplina do exército, não querem o serviço militar, do mesmo modo que não querem a disciplina do matrimônio uno, indissolúvel e fecundo que a Igreja impõe. É por isso que eu padre que amo apaixonadamente a minha Igreja, amo também apaixonadamente a minha Pátria. E por que amo a minha pátria, não posso resistir ao imperativo (...) de amar as suas forças armadas. (...)

\footnotetext{
${ }^{3}$ MAINWARING, Scott. Igreja Católica e política no Brasil (1916-1985). São Paulo: Brasiliense, 2004. p. 43

${ }^{4}$ Ibid. p. 43

${ }^{5}$ Ibid. p. 47.
} 
Eu amo o soldado como um pedaço da nossa bandeira.

Senhores! Na hora que possa mais que nunca, deveríamos bradar por toda a parte que o patriotismo não é apenas uma lei da natureza, lei promulgada pelas sanções da consciência universal dos povos: o patriotismo é uma lei sagrada, imposta por Deus.

Renegado aquele que foge ao cumprimento dessa lei; renegado quem foge à honra e ao dever de empunhar a espada do soldado brasileiro!

Renegado de Deus e dos homens quem se recusar à honra e á glória de morrer pela pátria. (...) Os homens têm razão de amaldiçoar a guerra. Nós amaldiçoamos também. A guerra é uma grande desgraça. Mas há uma desgraça maior: a desgraça da nação. ${ }^{6}$

No Estado do Paraná, também existiu a atuação do laicato católico, que foi pensada pela e organizada pela hierarquia da Igreja Católica. Névio de Campos mostrou que a Igreja Católica estabeleceu diversas estratégias para implementar o projeto romanizador, incentivando a formação de intelectuais leigos. A organização intelectual começou com a criação da União de Moços Católicos de Curitiba, em 1926, e com a constituição da imprensa católica. O projeto formativo postulado pelo laicato preconizava a formação integral da juventude. Em relação à educação religiosa, pensava-se na formação católica, pois para os católicos a maioria absoluta dos brasileiros professava o catolicismo. Por isso havia forte campanha em defesa do ensino religioso nas escolas públicas. ${ }^{7}$

A autora Margarita Victoria Rodríguez analisa a atuação de Alceu Amoroso Lima como intelectual que incentivava a educação católica. Ela utiliza os conceitos de Espiritualismo e neo-escolástica que estavam presentes no quadro intelectual brasileiro na Primeira República.

Importante nas investigações e na exposição sobre a Igreja Católica no período em questão é a História da Igreja no Brasil em sua terceira época, que foi escrita por Riolando Azzi, sendo complementada por Klaus Van der Grijp, autor da quarta parte - as Igrejas protestantes entre 1930 e 1964 . A partir dos anos 1920, segundo Riolando Azzi, a instituição católica desenvolveu um movimento intenso para reafirmar sua presença na área da educação da juventude,

\footnotetext{
${ }^{6}$ ARQUIVO DA CÚRIA METROPOLITANA. Correspondências D. Sebastião Leme. 1942.

${ }^{7}$ CAMPOS, Névio de. Intelectuais e Igreja Católica no Paraná: 1926-1938. Ponta Grossa: Editora UEPG, 2010. pp. 173-175.
} 
polemizando contra os que eram considerados seus adversários na disputa do espaço educacional: o protestantismo e o ensino leigo. Azzi destaca a convicção generalizada naquele momento que, mediante a formação das elites nos princípios cristãos, seria possível a criação de um Estado católico brasileiro. Por isso, multiplicaram-se as escolas católicas no país. ${ }^{8}$

No tocante ao protestantismo, um dos principais inimigos a ser combatido, na visão dos católicos, havia três razões para a rivalidade. Em primeiro lugar, sua doutrina era considerada uma heresia. Em segundo, os protestantes davam maior abertura para a educação sexual, valorização da mulher e para a democracia liberal. Por último, eram acusados de defender a hegemonia norteamericana no país, contrariando interesses brasileiros. ${ }^{9}$

Citando carta pastoral do cardeal D. Sebastião Leme, revela uma postura mais radical da Igreja com relação ao ensino leigo. Todo ensino que não fosse católico, seria considerado ateu. A escola pública era considerada como instrumento de difusão da descrença no país, daí a forte campanha desenvolvida para a introdução do ensino religioso nas escolas públicas. Concluíram os religiosos que estabelecimentos de ensino religiosamente indiferentes ou orientados por seitas não católicas não deveriam ser frequentados pelos católicos. Um outro fator relevante era que, com a difusão das escolas públicas, a instituição católica perderia parte expressiva de sua clientela. ${ }^{10}$

Riolando Azzi considera um clichê a definição de colégios de padres e freiras como destinados exclusivamente aos ricos. Ele chama a atenção para a educação profissional que as classes populares mereceram sempre aos cuidados da lgreja. Porém, houve sempre a defesa de uma sociedade hierarquizada por parte dos religiosos e as classes médias e altas estudavam nas escolas de internatos com melhores condições materiais e corpo docente especializado.

\footnotetext{
${ }^{8}$ AZZI, Riolando. GRIJP, Klaus Van der. História da Igreja no Brasil: ensaio de interpretação a partir do povo. Terceira época (1930-1964) Petrópolis: Vozes, 2008. p. 153

${ }^{9}$ Ibid. p. 154

${ }^{10}$ Ibid. p. $154-155$
} 
A diferença entre católicos e escolanovistas foi destacada de um modo mais apaixonadamente católico por Dilermando Ramos Vieira, em livro recentemente lançado História do Catolicismo no Brasil. No momento em que foi lançado o Manifesto dos Pioneiros da Educação Nova, em 1932, de clara orientação laicista, os educadores da Associação Brasileira de Educação, ligados à Igreja Católica, retiraram-se da organização, fundando em 1933 a Confederação Católica Brasileira de Educação. Em postura crítica a historiadoras da educação como Maria Luísa Santos Ribeiro e Otaíza de Oliveira Romanelli, o autor afirma que os educadores católicos não se opuseram à escola pública gratuita, mas rejeitaram a proposta da escola se tornar a expressão de um único anticonfessionalismo oficial. Essa ameaça, segundo o autor, "ocultava-se sob o eufemismo da educação neutra, que na prática se traduziria na irreligião do Estado, bem ao gosto de determinados grupos intelectualizados, indiferentes à sensibilidades da maioria". Alguns signatários eram agnósticos, como Edgar Süssekind de Mendonça e Armanda Álvaro Alberto ou afastados do ideário católico, como Anísio Teixeira. Com isso, o autor resgata o clima de rivalidades existente na época, em que Anísio Teixeira e Fernando de Azevedo foram chamados de comunistas. Sobrou também para Cecília Meireles, que teria afirmado ser 0 decreto do ensino religioso uma porta aberta para tristes ocorrências. ${ }^{11}$

Publicação didática e bem abrangente sobre o contexto da época é Nossa História: 500 anos de presença da Igreja Católica no Brasil de Henrique Cristiano José Matos. Ele destaca a grande militância da Igreja, a partir de Pio XI no Vaticano e de D. Leme no Brasil, a criação da Ação Católica, órgão articulador das organizações já existentes. No Brasil, a partir de 9 de junho de 1935, adotouse o modelo italiano da Ação Católica de cunho centralizador e autoritário, dividindo os leigos em quatro grupos, de acordo com idade e sexo: Homens da AC, para os maiores de 30 anos e os casados de qualquer idade; Liga Feminina da $A C$, para as maiores de 30 anos e casadas de qualquer idade; Juventude Católica Brasileira, para moços de 14 a 30 anos e Juventude Feminina Católica, para moças de 14 a 30 anos. Ressalta-se que a Ação Católica era uma

${ }^{11}$ VIEIRA, Dilermando Ramos. História do Catolicismo no Brasil: (1889-1945): Volume 2. Aparecida: Santuário, 2016. p. 217-218. 
arregimentação de militantes católicos leigos de classe média. O autor destaca pontos positivos da Ação Católica: amadurecimento do laicato católico, leigos que encontraram em seus quadros um instrumento para reavivar e fortalecer a fé, engajando-se no campo apostólico. ${ }^{12}$

Marta Maria Chagas de Carvalho destaca a atuação de Fernando de Azevedo no movimento por uma nova educação. Nos anos 1930, a liderar esse movimento exigia posicionar-se nos debates em que se antagonizavam defensores e críticos. Além de críticas do Pe. Helder Câmara no 1ํ Congresso Católico de Educação, sobre os excessos da pedagogia moderna, existiram as investidas de Leonardo Van Acker, sempre contrário à adesão dos católicos ao escolanovismo. Seus artigos seguiam a estratégia católica de ataque ao movimento de reforma educacional. Sua crítica identificava os principais adversários e mobilizava a arma que foi definitiva para neutralização do movimento, o anticomunismo. ${ }^{13}$

Dilermando Vieira ressalta que nos anos posteriores houve uma amenização da polêmica entre laicos e católicos. Alceu Amoroso Lima adotou metodologia baseada na liberdade, Lourenço Filho veio a insistir na formação espiritual da personalidade e Eduardo Backheuser que se converteu ao catolicismo. 14

Francisco Campos foi o mentor político e intelectual de Capanema no início dos anos 30. Os dois se encontravam sempre no Rio de Janeiro e faziam planos quanto ao futuro da política mineira. Campos era mais radical, a favor de um governo forte, livre das oligarquias tradicionais, ligadas ao Partido Republicano Mineiro e da democracia liberal. Desejava a substituição do governo tradicional por uma política própria, cujo principal instrumento seria a Legião de Outubro, um grupo, segundo os autores, que era a junção de organização governamental e sociedade civil. Outro objetivo de Campos era o envolvimento da Igreja Católica como fonte de inspiração ideológica e de legitimação política para a nova ordem.

\footnotetext{
${ }^{12}$ MATOS, Henrique Cristiano José. Nossa História: 500 anos de presença da Igreja Católica no Brasil. Tomo 3: período republicano e atualidade. $2^{a}$ edição. São Paulo: Paulinas, 2011. pp. 107-109.

${ }^{13}$ CARVALHO, Marta M. C. "Fernando de Azevedo, Pioneiro da Educação Nova". In: Revista do Instituto de Estudos Brasileiros. São Paulo, no 37, 1994. p. 77-78.

${ }^{14}$ VIEIRA, Dilermando. Op. Cit. p. 219.
} 
Este projeto é bastante similar ao fascismo, mas a vinculação com a lgreja é algo que foi tentado apenas em Portugal e, com maior sucesso, na Espanha.

A estratégia política de Campos pode não ter tido resultados mais imediatos, mas seu plano de estabelecimento de um pacto com a Igreja Católica deixou marcas mais intensas. Como Ministro da Educação, Campos deu apoio às chamadas emendas religiosas, entre elas a introdução do ensino religioso nas escolas públicas. A aliança com a Igreja, contudo, não era para Campos, uma questão de princípios. Ele percebia no cristianismo um instrumento de mobilização política e não um valor em si.

Em 26 de julho de 1934, Gustavo Capanema foi empossado no Ministério da Educação e Saúde, em substituição a Washington Pires, que havia sucedido a Francisco Campos, em setembro de 1932. Os autores fazem algumas sugestões sobre a escolha de Capanema para o Ministério. Pode ter sido uma compensação a Minas Gerais e ao grupo de Olegário Maciel. Capanema era preferido para assumir a presidência do Estado e fora surpreendido pela nomeação de Benedito Valadares. Evidências maiores apontam, no entanto, que a posse de Capanema se deva ao acordo entre Estado e Igreja, firmado anos antes por Francisco Campos, sendo que os religiosos viam no futuro ministro um homem de confiança. Capanema não possuía militância religiosa. Sua aproximação parece ter sido por ordem política. Mas havia uma diferença entre Campos e ele. Campos tinha em mente um projeto político ambicioso, no qual a Igreja era uma peça. Capanema, ao contrário, apoiou-se na Igreja para chegar ao Ministério e ficou limitado a esse apoio durante todo o seu mandato.

A época do ministério Capanema foi marcada por divergências entre diversos movimentos em torno da educação. A principal polarização foi entre a Escola Nova e a renovação católica. A grande bandeira da Escola Nova foi a educação pública, universal e gratuita. A educação deveria ser proporcionada para todos, sendo que todos deveriam receber o mesmo tipo de educação. Caberia ao setor público, e não a grupos particulares a realização desta tarefa, pela sua complexidade e tamanho. $O$ ensino deveria ser leigo. 
Havia também, conforme denominam os autores, o projeto fascista de Francisco Campos. Mentor intelectual do Estado Novo, sua concepção de governo era ditatorial para controle das massas. Em seu projeto político, havia lugar de destaque para a pedagogia, que deveria ter como meta primordial a juventude. Ao Estado, caberia a responsabilidade de organizá-la, modelando seu pensamento, ajustando-a ao novo ambiente político, preparando-a para a convivência a ser estimulada no autoritarismo. A Igreja Católica era importante nesse processo para que incentivasse o culto aos símbolos, aos mitos o temor ao governo. Com a aprovação das emendas religiosas e a nomeação de Capanema, ficou claro que o projeto de Campos não agradava à Igreja, que não desejava tamanha interferência do Estado.

Tensões aconteceram e foram inevitáveis. Em março de 1936, Capanema convidou Alceu Amoroso Lima para uma conferência no ministério sobre "a educação e o comunismo". Carlos Drummond resolveu não ir e colocou seu cargo à disposição. Outra polêmica envolvendo Alceu Amoroso Lima foi o veto ao nome de Fernando de Azevedo para o cargo de diretor nacional de Educação. Capanema buscava o convívio, a amizade e a colaboração dos intelectuais, tratando de colocar-se acima e alheio aos combates ideológicos nos quais todos estavam engajados, e que envolviam seu ministério.

A nacionalização de pessoas, áreas de influência estrangeira, escolas, fez parte da política varguista. Um dos motivos era a possibilidade de inserção do nazismo na sociedade brasileira. O fechamento de escolas, a proibição do ensino de língua estrangeira, os decretos relativos à importação do livro didático em língua estrangeira, a proibição da circulação de jornais em língua estrangeira. Todas essas medidas representavam para os grupos estrangeiros no país a interrupção de um processo cultural que vinha sendo mantido há quase um século.

Esse projeto novamente esbarrou e se chocou com a Igreja, que, principalmente no Sul, possuía muita força nos setores imigrantes e mantinha diversas escolas privadas. A posição do governo na área educacional era difícil. $O$ sistema privado, predominantemente confessional, era muito mais desenvolvido 
que o oficial e o governo não teria meios ou condições de substituí-lo. Muito menos incutir nos alunos os valores éticos e morais que faziam parte de uma cultura nacional revigorada.

A terceira parte do livro trata das reformas educacionais. Foi a área em que, segundo os autores, o pacto do Ministério da Educação com a Igreja se revelou com toda a sua força. Recém empossado no Ministério, Capanema recebeu de Alceu Amoroso Lima uma lista de medidas que esperava serem adotadas nas áreas da educação e trabalho. Alguns exemplos são: rigorosa exclusão do ecletismo pedagógico e do bolchevismo, publicação de pequenas ou grandes doutrinas antimarxistas e de documentação anti-soviética, facilidades do ensino religioso em todo o país e idem para a realização de congressos católicos de educação nos vários estados e em geral para os trabalhos da Ação Católica Brasileira. Para os trabalhadores, havia incentivo a publicações de toda a espécie, na base de uma concepção cristã do trabalho, inclusive distribuição gratuita de obras sadias e fáceis, de interesse para as classes operárias.

Das conseqüências do ministério Capanema, pode-se observar que a intenção de se estabelecer o controle sobre todo o processo de ensino e praticar o que foi feito na França, o modelo napoleônico, não foi possível, devido aos interesses particulares no tema educacional, notadamente da Igreja Católica. Se, no início, a Igreja pregava descentralização e a não estatização do ensino, cede, logo após, aos esforços centralizadores, desde que se mantivessem o ensino religioso e as escolas particulares. Segundo os autores, ao final do Estado Novo, o projeto educacional do Ministério da Educação havia exaurido seu conteúdo ético e mobilizador, deixando em seu lugar a parafernália de leis, instituições e rotinas que haviam sido montadas nos anos anteriores. Ficou para os anos seguintes, entre outros pressupostos, o de que ao Estado não cabe só o financiamento da educação pública, como também o subsídio à educação privada. O Ministério Capanema foi repleto de uma grandeza de intenções e talvez isso explique certa mística em torno de seu mandato e permita dizer, parafraseando Drummond, que ele faz falta. 
Um ponto que permite discussão maior é a afirmação de José Oscar Beozzo de que o Rio Grande do Sul ocupa lugar destacado e, em nenhum outro lugar do Brasil, nas regiões de colonização italiana ou alemã que se encontra a Igreja no exercício de uma absoluta hegemonia sobre a sociedade civil, com uma enorme vitalidade de vocações sacerdotais e religiosas, com uma rede de cooperativas de crédito, produção e consumo entre os colonos, uma sólida classe de pequenos proprietários, pequenos industriais e comerciantes inteiramente ligados à Igreja, uma rede de escolas, colégios e hospitais que não encontravam concorrente nem mesmo no Estado, jornais e boletins, e, também, laços importantes de militares e políticos com a Igreja. Igual atenção, segundo o autor, deveria ser dada a Minas Gerais, que superou com sua tradição católica o afastamento entre Estado e religião. ${ }^{15}$

Maiores pesquisas sobre o assunto podem levar a reflexões sobre Rio Grande do Sul e São Paulo, objeto deste estudo. No Sul, houve grande presença do protestantismo, assim como em São Paulo. Nas estatísticas escolares paulistas há considerável número de protestantes e espíritas. Em São Paulo, houve uma penetração um tanto forçada da Igreja no setor da educação, pública e privada, como ocorreu em outros lugares, principalmente após a aprovação das leis católicas estabelecidas pela Constituição de 1934. Outro ponto a ser relativizado é o da preocupação exclusiva da Igreja com a elite.

Beozzo afirma que toda a "questão escolar, ponto nevrálgico da disputa entre Igreja e Estado, não atingia a população pobre, inteiramente ausente do sistema escolar. Também a Igreja não se preocupava em abrir escolas para o povo, salvo na situação dos imigrantes das áreas de colonização do Sul, estando sua estratégia voltada para os filhos das classes dominantes." 16

As considerações de Riolando Azzi relativizam em parte a questão da elitização e alguns dados relativos à Inspetoria Arquidiocesana do Ensino

\footnotetext{
${ }^{15}$ BEOZZO, José Oscar. A Igreja entre a Revolução de 1930, o Estado Novo e a Redemocratização. In: FAUSTO, Boris. História da Civilização Brasileira: O Brasil Republicano: Economia e cultura - 1930-1964. Tomo II, v. $4^{\circ}$. Rio de Janeiro: Bertrand-Brasil, 1997. p. 275.

${ }^{16}$ Ibid. p. 281.
} 
Religioso dão conta da tentativa da Igreja em se aproximar de setores mais populares.

Para Maria Luiza Marcílio, a educação na cidade de São Paulo sofreu profundas mudanças a partir de 1930, a maior delas a integração definitiva da escola na paisagem urbana e na vida cotidiana da população. $O$ analfabetismo, conforme os dados de Lourenço Filho, era de $65,3 \%$ em 1900; caiu para 56,2\% em 1940. O ensino primário foi objeto de preocupação de especialistas e da ação do poder público nos anos 1930. A autora analisa o Manifesto dos Pioneiros da Educação Nova de 1932 como uma proposta de reconstrução nacional no âmbito educacional. A educação deveria ser um direito fundamental de todos e de cada um. Reivindicavam-se a laicidade do ensino público, sua gratuidade, sua obrigatoriedade e a coeducação. ${ }^{17}$

Em 1930, a cidade de São Paulo contava com 50 grupos escolares que reuniam 1.233 classes, com 58.689 alunos matriculados, além de 119 escolas isoladas, onde lecionava apenas um único professor, com 2.840 alunos. Acrescidos os 363 estabelecimentos de ensino particular, o município possuía um total de 532 estabelecimentos de ensino primário, de porte e dimensões variados, com um total de 105.413 alunos. Em 1945, eram 134.771 alunos só nas instituições públicas. ${ }^{18}$

Trabalhos mais recentes, como algumas teses e artigos, vêm observando com maiores detalhes e variedade de fontes a relação entre a Igreja Católica e a política brasileira

Lilian Rodrigues de Oliveira Rosa, em sua tese, apresenta os objetivos da Santa Sé e sua estratégia de inserção na política brasileira, a partir dos anos 20 , com análise de documentos do Arquivo Secreto do Vaticano. Para a autora, a Doutrina Social da Igreja tornou-se a base doutrinária sobre a qual se assentou, a

\footnotetext{
${ }^{17}$ MARCíliO, Maria Luiza. História da escola em São Paulo e no Brasil. $2^{a}$ ed. São Paulo: Imprensa Oficial do Estado de São Paulo: Instituto Fernand Braudel de Economia Mundial, 2014. pp. 232 a 234.

${ }^{18}$ Ibid. p. 249.
} 
partir de 1932, no Brasil, a implantação da Ação Católica, com ênfase no trabalho do laicato junto ao operariado. Foi também, o fundamento para o apoio quase incondicional da Igreja Católica ao aprimoramento e à intensificação dos mecanismos repressivos do Estado contra os movimentos sociais.

Com apoio na documentação do Vaticano, a autora pormenoriza a ação romana sobre a penetração do comunismo no Brasil, principalmente com o movimento operários. Para a Secretaria de Estado da Santa Sé, "era preciso estruturar 'táticas de combate' mais eficientes para conter o avanço de crenças concorrentes, como o protestantismo, e para substituir o ideal comunista pelo ideal de catolicismo social." ${ }^{\prime 19}$

Dom Leme fundou a Confederação Católica em 1922, que além de reunir grupos também possuía comissões mais especializadas, como a Comissão de Fé e Moral, que atuava na vigilância de protestantes e espíritas.

19 ROSA, Lílian Rodrigues de Oliveira. A Igreja Católica Apostólica Romana e o Estado Brasileiro. Estratégias de inserção política da Santa Sé no Brasil entre 1920 e 1937. 2011. 278f. Tese (Doutorado em História) - Faculdade de Ciências Humanas e Sociais, Universidade Estadual Paulista "Júlio de Mesquita Filho", Franca, 2011. p. 211. 
Capítulo 2

A luta política pelo Ensino Religioso 
A Igreja Católica, através de suas principais personalidades e da Ação Católica, fundada no Brasil em 1935, pressionou pela aprovação do Ensino Religioso nas escolas. Foram grandes as discussões e polêmicas, principalmente através da imprensa e debates sobre como seria a presença do ensino em instituições públicas.

O decreto autorizando e regulamentando o Ensino Religioso nas escolas públicas do Brasil foi assinado por Getúlio Vargas em 30 de abril de 1931, sendo ele posteriormente incorporado na Constituição de 1934. O texto apresentava o caráter facultativo do ensino da religião nos estabelecimentos de instrução primária, secundária e normal. Os pais podiam requerer a dispensa dos alunos, era necessário um grupo mínimo de 20 alunos para que o curso pudesse acontecer, a organização e a escolha de material ficavam a cargo dos ministros do respectivo curso e qualquer dúvida que pudesse surgir a respeito da interpretação do decreto deveria ser resolvida de comum acordo entre as autoridades civis e religiosas a fim de "dar às consciências das famílias as garantias de autenticidade e segurança do ensino religioso".

\section{Decreto no 19.941, de 30 de Abril de 1931}

Dispõe sobre a instrução religiosa nos cursos primário, secundário e normal

O Chefe do Governo Provisório da República dos Estados Unidos do Brasil DECRETA:

Art. 1ำ Fica facultado, nos estabelecimentos de instrução primária, secundária e normal, o ensino da religião.

Art. $2^{\circ} \mathrm{Da}$ assistência às aulas de religião haverá dispensa para os alunos cujos pais ou tutores, no ato da matrícula, a requererem.

Art. 3 o Para que o ensino religioso seja ministrado nos estabelecimentos oficiais de ensino é necessário que um grupo de, pelo menos, vinte alunos se proponha a recebê-lo.

Art. $4^{\circ} \mathrm{A}$ organização dos programas do ensino religioso e a escolha dos livros de texto ficam a cargo dos ministros do respectivo culto, cujas comunicações, a este respeito, serão transmitidas às autoridades escolares interessadas.

Art. 5ㅇ A inspeção e vigilância do ensino religioso pertencem ao Estado, no que respeita a disciplina escolar, e às autoridades religiosas, no que se refere à doutrina e à moral dos professores.

Art. 6o Os professores de instrução religiosa serão designados pelas autoridades do culto a que se referir o ensino ministrado.

Art. $7^{0}$ Os horários escolares deverão ser organizados de modo que permitam os alunos o cumprimento exato de seus deveres religiosos. 
Art. 8ำ A instrução religiosa deverá ser ministrada de maneira a não prejudicar o horário das aulas das demais matérias do curso.

Art. 9 Não é permitido aos professores de outras disciplinas impugnar os ensinamentos religiosos ou, de qualquer outro modo, ofender os direitos de consciência dos alunos que lhes são confiados.

Art. 10. Qualquer dúvida que possa surgir a respeito da interpretação deste decreto deverá ser resolvida de comum acordo entre as autoridades civís e religiosas, afim de dar à consciência da família todas as garantias de autenticidade e segurança do ensino religioso ministrado nas escolas oficiais.

Art. 11. O Governo poderá, por simples aviso do Ministério da Educação e Saude Pública, suspender o ensino religioso nos estabelecimentos oficiais de instrução quando assim o exigirem os interesses da ordem pública e a disciplina escolar.

Rio de Janeiro, 30 de abril de $1931,110^{\circ}$ da Independência e $43^{\circ}$ da República.

GETÚLIO VARGAS.

Francisco Campos. ${ }^{20}$

Nos dias seguintes à publicação do decreto, o jornal O Estado de São Paulo publicou quase diariamente, durante os meses de maio e junho de 1931 , cartas, moções e telegramas dos que apoiavam a medida e dos que a rejeitavam. Muitas associações religiosas católicas sentiram-se agraciadas e muitas outras discordaram em nome do caráter laico das instituições e também da possível predileção dada ao ensino católico, em detrimento de outros cultos.

Já no dia 2 de maio de 1931, o Estado de S. Paulo publicou os telegramas de grupos de várias partes do Brasil contrários ao Ensino Religioso. Um grupo de liberais da Sociedade Teosófica de São Paulo lamentou o decreto que consideraram atentatório aos princípios republicanos e feriam a consciência íntima de cada cidadão, solicitando ao governo a imediata revogação de qualquer iniciativa nesse teor para "tranquilidade dos espíritos". ${ }^{21}$

O Comitê Central Pró Liberdade de Consciência, sediado em Porto Alegre, queria a fundação desses mesmos comitês em todas as cidades do Brasil, constituídos de todos os credos acatólicos, sem tom de religião ou política, para o fim de dar combate por todos os meios lícitos, às pretensões do clero católico de pleitear assistência espiritual nas forças armadas, Ensino Religioso nas escolas e

\footnotetext{
${ }^{20} \mathrm{http} / / / \mathrm{www} 2 . c a m a r a . l e g . b r /$ legin/fed/decret/1930-1939/decreto-19941-30-abril-1931-518529publicacaooriginal-1-pe.html

${ }^{21}$ O Estado de S. Paulo 02.05.1931.
} 
reconhecimento oficial da cerimônia do casamento católico. Eles queriam que fosse mantido o parágrafo 7 do artigo 72 da Constituição de 1891, pelo qual nenhuma religião ou culto teria dependência com o Estado. Esperavam, de acordo com o telegrama, "que todos os homens livres de nossa terra se unam conosco nesta cruzada de são patriotismo, formando frente em defesa da liberdade e do direito".

Em Campinas, foi criado, na sequência, um Comitê Pró Liberdade manifestando, em publicação no jornal, o aproveitamento de muitas inteligências intolerantes, num momento de exceção da vida político-partidária brasileira, que pretendiam unificar religião e governo no país, gerando desigualdade entre os filhos da mesma pátria e desarmonia social. Lançaram um chamado aos brasileiros que não pretendiam impor suas crenças ao país, compreendendo as causas da Revolução de 30 e não querendo continuar à beira do abismo de uma guerra civil. Só compreenderiam restrições às liberdades e direitos conquistados desde 1891 como um passo retrógrado da civilização brasileira e como gravíssima ameaça a todos os diretos do homem no Brasil. ${ }^{22}$

No dia seguinte foi a vez da Loja Maçônica Libertas de São Paulo protestar contra o decreto do Ensino Religioso, considerando um atentado à Constituição de 1891, que Getúlio Vargas havia prometido fazer respeitar, segundo a associação. $O$ fato faria retroceder quarenta anos nas conquistas liberais e representaria o primeiro passo para a oficialização de determinada religião que não era da totalidade dos brasileiros. Como consequência, existiriam a discórdia entre a família brasileira e a sua desunião provocada pelo entrechoque das diversas religiões. ${ }^{23}$

Um telegrama com assinatura de 70 mulheres também foi enviado a Getúlio Vargas e publicado pelo Estado de S. Paulo. O documento dizia que a mulher paulista, alarmada com as desastrosas consequências que certamente adviriam do decreto que instituía o Ensino Religioso nas escolas, protestava

${ }^{22}$ O Estado de S. Paulo 02.05.1931.

${ }^{23} \mathrm{O}$ Estado de S. Paulo 03.05.1931. 
energicamente contra tal medida "regressora e atentadora aos nossos foros de povo livre".

Outro apelo vinha da Convenção Batista Paulista, representante de 42 igrejas com cinco mil membros, protestando contra a implantação do Ensino Religioso em escolas públicas, mesmo com o caráter facultativo que seria facilmente burlável pela maioria católica, orientada pelos padres. A União da Mocidade Batista também protestou manifestando decepção pelo fato da assinatura do decreto considerado antagônico aos princípios e razões apresentados por Vargas, combatendo a medida que já havia sido pleiteada por Artur Bernardes. ${ }^{24}$

De Limeira, SP, foi enviado um telegrama ao chefe do governo provisório, Getúlio Vargas protestando, em nome do povo livre e liberal daquela cidade, contra o decreto, atentatório da liberdade de pensamento com o Ensino Religioso nas escolas para satisfazer caprichos, ferindo princípios garantidos pela Constituição de 1891, que o governante prometera respeitar. O manifesto esperava a revogação do ato, o que traria a simpatia e o apoio de todos os liberais do Brasil. ${ }^{25}$

Moções de aplauso também foram publicadas com felicitações e regozijo. Os membros da Confraria Rosário Santa Efigênia de São Paulo vibraram com entusiasmo pela assinatura do decreto, fator de formação da sociedade e grande futuro para a terra brasileira. $O$ apostolado da Oração de Santa Efigênia de São Paulo, convencido que a verdadeira educação religiosa só dignificava a sociedade e concorria para atenuar inevitáveis desigualdades humanas, cumprimentava Getúlio Vargas. ${ }^{26}$

A Liga das Senhoras Católicas, de acordo com o telegrama, constituída pelas principais famílias paulistas, congratulou-se com a promulgação auspiciosa do decreto, assegurando liberdade de instrução religiosa. A publicação afirmava que Vargas e Francisco Campos acabavam de satisfazer grande aspiração do

\footnotetext{
${ }^{24}$ O Estado de S. Paulo. 03.05.1931.

${ }^{25}$ O Estado de S. Paulo. 05.05.1931.

${ }^{26}$ O Estado de S. Paulo. 05.05.1931.
} 
povo brasileiro conquistando para seu governo gratidão, consciência católica que representava voto quase unânime da nação. A Congregação Mariana de Santa Cecília, de São Paulo apresentou entusiástica solidariedade na "atitude corajosa e digna" da instituição do Ensino Religioso nas escolas, "alicerce único de uma Pátria moralmente forte e organizada". O Centro Dom Vital de São Paulo, representando a intelectualidade católica paulista, congratulou-se calorosamente com Vargas pela instituição do Ensino Religioso facultativo nas escolas. Do mesmo modo, a Ação Universitária Católica manifestou absoluta adesão ao "magnífico decreto", indício seguro de uma nova fase de regeneração para o Brasil. 27

Um artigo no dia 5 de maio de 1931, de Herman Corrêa, profetizou um verdadeiro caos que poderia se instalar por causa da determinação governamental. Para ele, os católicos não deviam aceitar o decreto. Primeiro porque ele só poderia ser decidido pelos representantes da nação legitimamente eleitos e também, não fazia parte do programa da Revolução de 1930. O gesto nobre do Episcopado brasileiro, não aceitando o decreto e aguardando o pronunciamento da Nação Brasileira em Constituinte, seria recebido com aplauso unânime para evitar o incêndio de uma luta religiosa. Segundo o articulista, as escolas públicas iriam se constituir em campos de luta, de batalha tremenda, num ambiente terrível de discussões prejudiciais à formação do espírito infantil. Os menores que assistissem às aulas, em que se "papaguevam" automaticamente perguntas e respostas, tornar-se-iam adversários dos que não assistissem.

O superintendente da escola Dominical da Igreja Presbiteriana de Sorocaba, Abdiel Monteiro, protestou devido ao favorecimento que a nova lei daria ao credo católico romano, sendo as escolas públicas mantidas com impostos pagos por cidadãos de todos os credos. Ele achava injusto proporcionar à Igreja Romana tal meio de fazer propaganda das suas doutrinas. A exemplo do que fazia o protestantismo, competia à família e às igrejas o Ensino Religioso. ${ }^{28}$ 
Em Ribeirão Preto, foi constituído o Comitê Pró-Liberdade de Pensamento. Um telegrama seria enviado a Getúlio Vargas por 50 pessoas cujos filhos estudavam nas escolas públicas da cidade, consultando-o sobre a possibilidade da não revogação do decreto do Ensino Religioso que podia contar como certa a nomeação de professores e professoras para lecionar doutrina espírita, pois "o espiritismo é uma religião tão respeitada como qualquer outra." 29

Os membros da Loja Maçônica Quintino Bocaiúva manifestaram respeito profundo e absoluto por todas as crenças religiosas, temendo pelo futuro desta grande nação que devia o melhor de seus progressos à tolerância religiosa e ensino laico. Resolveram exarar na ata da sua sessão de 05 de maio, um voto de protesto contra o decreto, com grave prejuízo para o ensino e desrespeito às crenças e conhecimentos pedagógicos do professorado. ${ }^{30}$

No dia 5 de junho de 1931, Francisco Campos recebeu uma comissão de sexto-anistas do externato do Colégio Pedro II, que Ihe foi pedir o Ensino Religioso nos termos do decreto do governo provisório. De acordo com o Estado de $S$. Paulo, era o primeiro pedido que se fazia nesse sentido. O manifesto, assinado por trinta e dois alunos, pedia ao Ministro para providenciar para que fosse ministrado o ensino da religião católica apostólica romana e acordo com o "recente e luminoso ato" do governo provisório da República, que facultava a prática nos estabelecimentos de instrução secundária do país.

Universitários do Rio de Janeiro, em número de 600, dirigiram a Getúlio Vargas um manifesto de apoio dizendo trazerem o sincero e consciente aplauso à medida acatadora de todas as crenças, levando nela o governo até os extremos do escrúpulo, o seu respeito à liberdade das consciências. Os estudantes argumentavam que a lei tornava facultativo o ensino da religião, que a ninguém era imposto. No período anterior, impunha-se a toda a consciência religiosa ou não a aceitação de uma doutrina agnóstica ou ateísta. $O$ ato do governo, segundo

${ }^{29}$ O Estado de S. Paulo. 09.05.1931
${ }^{30}$ O Estado de S. Paulo. 13.05.1931 
os universitários, alinhava-se com os povos ditos civilizados do mundo, como Alemanha, Holanda, Itália, Inglaterra, Iugoslávia, Polônia, Irlanda, Escandinávia. ${ }^{31}$

A série de mensagens contraditórias de manifestações divergentes que o decreto provocou, para os estudantes, serviram para criar uma situação de discrepância e desacordo que não existia na sociedade, pois no regime anterior de absoluta laicidade do ensino, nunca se manifestara a desarmonia espiritual nos meios escolares brasileiros. Esta surgiu evocada pela disposição criada pelo Ministro da Educação, sem que houvesse na opinião pública uma qualquer solicitação em seu favor.

Uma publicação no mesmo dia 6 de junho de 1931 apontava a convocação de um comício de protesto contra o decreto do Ensino Religioso nas escolas. A reunião popular aconteceria no dia seguinte no Largo da Concórdia. ${ }^{32}$

Em 7 de agosto de 1931, foi publicado o Decreto Estadual ํo 5.152, regulamentando o Ensino Religioso no Estado de São Paulo, em conformidade com o Decreto Federal.

DECRETO N. 5.152, DE 7 DE AGOSTO DE 1931

Dá regulamento ao ensino religioso nas escolas publicas.

O DOUTOR LAUDO FERREIRA DE CAMARGO, Interventor Federal no Estado de São Paulo, considerando que o Decreto Federal n.o 18.941, de 30 de abril do corrente ano, faculta nos estabelecimentos de, Instrução primaria, secundaria e normal, 0 ensino religioso; considerando que se torna necessária a regulamentação desse Decreto, para que possa ser aplicado nos estabelecimentos de ensino oficial do Estado,

Decreta:

Art. 1. - Fica facultado, nos termos deste Decreto, em todos os estabelecimentos de ensino primário, secundário e normal do Estado, o ensino

de

qualquer

religião.

Art. 2. - Para que o ensino de determinado culto seja ministrado em estabelecimentos oficiais, é necessário que um grupo de vinte alunos, no mínimo, em cada estabelecimento se propõe a recebê-lo, mediante requerimento dos pais ou tutores.

${ }^{31}$ O Estado de S. Paulo 06.06.1931 
§ 1. - O requerimento deve ser feito por escrito e dirigido ao diretor geral do ensino, por intermédio do professor em se tratando de escola isolada, ou por intermédio do diretor, em se tratando de escolas reunidas, grupo escolar, ginásio ou escola normal.

§ 2. - Tomando conhecimento do requerido o diretor geral do Ensino solicitará, incontinenti, da autoridade do culto a que se referir o ensino pretendido, a designação do respectivo professor; e feita essa designação, a Diretoria Geral do Ensino determinara a data do inicio das aulas e horário conveniente, de modo a não prejudicar o horário das aulas das demais matérias do curso.

Art. 3. - - A partir do próximo ano letivo, nos estabelecimentos em que estiver organizado o ensino religioso, se entregará ao país ou tutor de cada aluno, no ato da matricula uma ficha em que declarará si aceita ou não o ensino religioso e qual 0 culto pretendido.

Art. 4. - - A organização dos programas de ensino religioso e a escolha dos livros de texto ficam a cargo dos ministros do respectivo culto, que comunicarão esse programa e escolha à Diretoria Geral do Ensino. Art. 5. - A inspeção e vigilância do ensino religioso pertencem ao Estado, no que respeita á disciplina escolar, e ás autoridades do culto a que se referir, no que diga respeito á doutrina e á moral dos encarregados desse ensino.

Art. 6. - Não é permitido aos professores de outras disciplinas impugnar os ensinamentos religiosos ou, de qualquer outro modo, ofender os direitos da consciência dos alunos que Ihes são confiados; assim como não é dado aos encarregados do ensino religioso estabelecer debate sobre conclusões de matéria científica.

Art. 7. - Aos professores do Estado é expressamente vedado fazer, dentro das escolas, propaganda de qualquer credo religioso, no sentido de influir que seus alunos aceitem o ensino da doutrina e culto respectivos, assim, como externar ou manifestar suas convicções e preferências, diante dos alunos.

§ único. - Em nenhuma escola oficial, será permitida durante as aulas comuns, a existência de símbolos de qualquer culto, e bem assim a distribuição de folhetos ou Impressos de propaganda religiosa.

Art. 8.․ - Qualquer duvida que possa surgir a respeito da interpretação deste Decreto deverá ser resolvida de comum acordo entre as autoridades civis e religiosas, a fim de dar à consciência das famílias todas as garantias de autenticidade e segurança do ensino religioso ministrado nas escolas oficiais.

Art. 9. - O governo poderá por simples aviso do Secretario da Educação, suspender o ensino religioso nos estabelecimentos oficiais de instrução, quando assim o exigirem os interesses de ordem publica e a disciplina escolar.

Art. 10. - Este Decreto entra em vigor na data de sua publicação, revogadas as disposições em contrario.

Palácio do Governo do Estado de São Paulo, aos 7 de agosto de 1931.

LAUDO FERREIRA DE CAMARGO,

A. de Almeida Prado.

Publicado na Secretaria da Educação e da Saúde Publica, em 7 de agosto de 1931.

A. Meirelles Reis Filho, Director Geral. ${ }^{33}$

\footnotetext{
${ }^{33}$ http://www.al.sp.gov.br/repositorio/legislacao/decreto/1931/decreto-5152-07.08.1931.html
} 
Porém, no dia 24 de dezembro de 1931, com o Decreto Estadual no 5.305, o interventor Manoel Rabello (1873-1945) revogou o Decreto Estadual 5.152 do antecessor Laudo Ferreira de Camargo (1881-1963):

\section{DECRETO N. 5305, DE 24 DEZEMBRO DE 1931}

Revoga o Decreto n. 5132, de 7 de agosto de 1931.

O CIDADÃO CORONEL MANOEL RABELLO, Interventor Federal no Estado de São Paulo, usando das atribuições que the confere o Decreto Federal n. 19398, de 11 de novembro de 1930, art 11, '\$ 1...; e, considerando que o Decreto n. 5152, de 7 de agosto de 1931, que regulamentou o ensino religioso nas escolas publicas, tem motivado varias reclamações que ao Governo compete prevenir;

Decreta:

Art. 1. - - Fica revogado o decreto n. 5152, de 7 de agosto de 1931.

Art. 2.- - Este decreto entra em vigor na data de sua publícação, revogadas as disposições em contrario,

Palácio do Governo do Estado de São Paulo, aos 24 de dezembro de 1931.

CEL. MANOEL RABELLO.

Salles Gomes Junior.

Publicado na Secretaria de Estado da Educação e da Saúde Publica, em 21 de dezembro de 1931,

A. Meireles Reis Filho, Diretor Geral. ${ }^{34}$

Alguns dias depois, o Arcebispo D. Duarte Leopoldo reclamou a Getúlio Vargas contra 0 ato considerado inesperado do interventor federal proibindo 0 Ensino Religioso nas escolas públicas. Para ele, revogando implicitamente decreto federal, desconhecia o princípio fundamental da hierarquia política, estabelecendo confusão geral nos espíritos, criando graves apreensões, quando se precisava de paz e tranquilidade para a consolidação política do país. D. Duarte não compreendia que em nome da liberdade de consciência pretendesse o sectarismo positivista embaraçar exercício de crenças religiosas da maioria da população paulista. Alguns protestos, segundo ele, de insignificante minoria, sem

\footnotetext{
${ }^{34}$ http://www.al.sp.gov.br/repositorio/legislacao/decreto/1931/decreto-5305-24.12.1931.html
} 
reflexo na opinião pública, não deviam prevalecer contra a vontade manifesta da população quase unânime. O Arcebispo informou que só em São Paulo, o Ensino Religioso funcionava em quarenta e seis grupos escolares, com cinquenta e cinco mil alunos, duas escolas normais superiores com mil alunos, além das escolas do interior da arquidiocese. "Os acatólicos não conseguiram organizar um único agrupamento para ensino do respectivo credo". Dentre mil e quinhentas normalistas que funcionam na capital, cerca de mil e duzentas estão espontaneamente inscritas para Ensino Religioso em suas respectivas classes. $E$ pediu que Vargas restituísse a liberdade concedida. ${ }^{35}$

Em edição de $1^{\circ}$ de janeiro de 1932, o Estado de S. Paulo publicou alguns telegramas da loja maçônica América de São Paulo, capital, saudando a revogação do decreto que regulamentava o Ensino Religioso no Estado. Ao interventor federal Manuel Rabello, afirmou que a revogação significava o restabelecimento dos princípios liberais e republicanos. A Getúlio Vargas, enfatizou a liberdade de pensamento e consciência, impedindo a continuação de disputas religiosas no seio das escolas e exigiu a igual revogação do decreto federal que trata do assunto. Ao Ministro da Justiça, Maurício Cardoso, pleiteou atuação junto a Getúlio Vargas para revogação do decreto federal o que viria a restabelecer a paz nas escolas e a harmonia na família brasileira. $O$ interventor Manuel Rabello recebeu, além disso, telegramas de aplauso da Loja Quintino Bocaiúva, da diretoria da Igreja Evangélica Batista Paulistana, de diversos membros da mesma Igreja, da diretoria da Sinagoga Espírita e do Templo Espiritualista Samuel. ${ }^{36}$

$\mathrm{Na}$ mesma edição, um editorial afirmava que vivíamos no regime da completa separação do Estado e da Igreja. Desde o decreto no 119-A de 7 de janeiro de 1890, a todas as confissões religiosas pertencia "por igual a faculdade de exercerem o seu culto, regerem-se segundo a sua fé e não serem contrariadas nos atos particulares do público que interessem o exercício deste direito". A todas as Igrejas e confissões religiosas se reconheceu também "a personalidade jurídica para adquirirem bens e os administrarem". E, de acordo com a

\footnotetext{
${ }^{35}$ O Estado de S. Paulo. 27.12.1931

${ }^{36}$ O Estado de S. Paulo. 01.01.1932
} 
publicação, graças à sabedoria desse regime, a Igreja Católica foi libertada da fiscalização incômoda e, por vezes vexatória exercida pelo governo imperial sobre ela. Nunca mais se reproduziu, nos quarenta anos de República, o lamentável espetáculo que foi a célebre questão com os bispos de Olinda e Pará, que tantos abalos provocou na sociedade brasileira e tantos sofrimentos produziu aos católicos e à Santa Sé.

Seguindo o editorial, afirma que a Constituição de 1891 sintetizou o princípio liberal da lei de 1890 na frase do seu artigo 11: "é vedado aos Estados, como à União, estabelecer, subvencionar ou embaraçar o exercício de cultos religiosos", disposição que foi corroborada e ampliada pelas do parágrafo $3^{\circ}$ do artigo 73: "Todos os indivíduos e confissões religiosas podem exercer, pública e livremente, o seu culto, associando-se para esse fim e adquirindo bens, observadas as disposições do direito comum". Completando esses preceitos determinou ainda a Constituição de 1891, nos parágrafos 5, 6 e 7 a secularização dos cemitérios, "ficando livre a todos os cultos religiosos a prática dos respectivos ritos em relação aos seus crentes desde que não ofendam à moral pública e às leis", a laicidade do ensino, ministrado nos estabelecimentos públicos, e a separação absoluta da Igreja do Estado: "Nenhum culto ou Igreja gozará de subvenção oficial nem terá relações de dependência ou aliança com o governo da União ou o dos Estados."

O texto fez menção à reforma constitucional promovida pelo presidente Artur Bernardes, em 1925-1926, na qual se procurou alterar o texto relativo ao ensino com a emenda que o Congresso rejeitou: "conquanto leigo, o ensino com caráter obrigatório, ministrado nas escolas oficiais, não exclui das mesmas 0 ensino religioso facultativo". O que o Congresso não fez, segundo o jornal, fez o governo provisório convertendo em lei, sem maior reflexão, a emenda repelida. $O$ que, no seu liberalismo cauteloso, receavam os adversários dessa emenda foi o que sucedeu: surgiu, imediatamente, nas escolas, uma verdadeira questão religiosa.

O editorial não contestou o valor moral do Ensino Religioso, alimentado pelo cristianismo. Mas, diante do "perigo" de se armar, nas escolas públicas, 
mantidas com as contribuições de cristãos e não cristãos, conflitos graves, que perturbariam a liberdade de todos, defende o regime que a Constituição de 1891 adotou. Vedado nas escolas públicas, segundo o Estado de S. Paulo, o Ensino Religioso seria livre nas particulares e no seio das famílias conservando o Estado, nessa matéria, como em todas que toca à consciência e aos sentimentos dos cidadãos, impecável neutralidade e imparcialidade irrepreensível. A luta religiosa levá-lo-ia, mais cedo ou mais tarde, quisesse ele ou não, a pender para um lado ou para outro, o que agravaria a situação e viria a dar, no final das contas, em perseguição a este ou àquele credo religioso.

No modo de pensar dos editorialistas, além do argumento da experiência, que é o decisivo, existiu, da mesma forma, a opinião insuspeita de eminentes figuras do clero católico do Brasil. Entre elas, o sacerdote que foi o primeiro bispo de Campinas, D. João Nery, o qual não ocultava o seu aplauso à Constituição do Brasil na parte relativa às relações entre a Igreja e o Estado, sustentando que a Igreja se sentia inteiramente à vontade, no regime republicano, para o exercício do seu culto, propagação da fé e ensino de sua doutrina. Havia, nesta casa, afirmou o jornal, quem tivesse ouvido essas afirmações, por mais de uma vez dos próprios lábios daquele venerando príncipe da Igreja.

Era compreensível que os católicos, constituindo a maioria, pleiteassem a adoção do Ensino Religioso facultativo, nas escolas públicas, de acordo com a coluna. Acreditando que estão na posse da verdade divina e achando-se mais numerosos que os outros, seria natural que pretendessem conquistar para o seu credo os recalcitrantes, impedindo-os de sofrer as seduções das outras prédicas. "É isso da índole de todo crente e está na substância de toda igreja". Para o jornal Estado de S. Paulo, a intolerância era o traço característico de toda a fé ardente. Os santos eram apenas intolerantes com os próprios erros, mas os não santos viravam a intolerância contra os outros. "Ora, a massa geral de crentes não é composta de santos..."

Mas se a tendência incoercível da Igreja era alargar a esfera da sua atividade, ainda segundo o jornal, era dever do Estado, guarda e protetor de todas as crenças e da liberdade de todos os cultos, conter essa tendência em limites 
razoáveis, a fim de que, na sua expansão, não vá ferir as outras crenças e tolher a liberdade dos outros cultos. A maneira mais prática de exercer esse direito era, precisamente, a que a Constituição indicou afastar de todos os serviços públicos, a principiar pelo ensino, a intromissão do elemento religioso.

Se o governo revolucionário houvesse respeitado a tradição liberal que, em assuntos religiosos, a República criou, não se estaria assistindo a agitação perigosa que desencadeou nos círculos católicos, a revogação da faculdade de se ministrar o Ensino Religioso nas escolas públicas. "Essa agitação foi obra exclusiva e inútil do governo provisório, o qual, com uma imprudência imperdoável em estadistas experimentados", reacendeu uma fogueira que estava extinta e cujas labaredas ninguém sabe até onde irão ter e o que virão a consumir. Encerrando a publicação, afirma-se nunca ter vindo tão a propósito, aplicando-a ao governo provisório, a citação da célebre frase do Papa quando foi da questão religiosa entre o governo imperial e os bispos: 'Non laudatur gesta tua' ${ }^{37}$

No dia seguinte, em resposta, foi publicado um artigo do Monsenhor Gastão Liberal Pinto, na Seção Livre, espaço diversas vezes impresso com o título: 'O Ensino Religioso nas escolas'. Segundo o sacerdote, não havia deixado de surpreender a nota publicada no Estado do dia anterior, sobre o Ensino Religioso nas escolas públicas e a respeito ele pediu para fazer observações notadamente em defesa do decreto federal e contra a sua revogação feita pelo interventor federal Manoel Rabelo.

Para Gastão Lilberal, certas fórmulas repetidas com insistência criaram entre o povo um ambiente e mentalidade que faziam desconhecer e perder 0 contato com a realidade da consciência nacional. Uma prova desta deformação mental operada em todas as camadas da sociedade resultava da comparação entre o sectarismo positivista daquele momento e o que Teixeira Mendes havia escrito no Jornal do Comércio, de 8 de junho de 1904, então o mais autorizado representante da Igreja Positivista no Brasil. Mendes havia afirmado ser a educação impossível sem culto e sem um Ensino Religioso qualquer. Porque não era concebível educar ninguém sem inculcar-lhe hábitos de moralidade e

\footnotetext{
${ }^{37}$ O Estado de S. Paulo, 01.01.1932
} 
fornecer-lhes as noções que explicassem esses hábitos. Ou dava-se essa cultura moral e mental ou não se educava. Uma criança não estava habilitada para escolher a sua religião e muito menos para rejeitar todas. A opção competia naturalmente aos seus pais e especialmente às suas mães... $O$ respeito à liberdade espiritual prescrevia que se acatasse nos filhos menores as convicções religiosas de seus pais. O decreto de 30 de abril de 1931, para ele, outra coisa não fez senão aplicar às escolas públicas de todo o Brasil a sabedoria dos princípios universais aceitos por todas as legislações dos países ditos civilizados. ${ }^{38}$

O religioso afirmou que quem se desse ao trabalho de fazer uma excursão no terreno da legislação escolar comparada veria como as nações modernas, muitas incomparavelmente mais divididas que o Brasil, sob o ponto de vista religioso, tomaram na devida consideração a convicção religiosa de sua população e esforçam-se por encontrar a fórmula jurídica do respeito à liberdade de consciência na adoção do Ensino Religioso em harmonia com a vontade das famílias. Assim, a Alemanha, na Constituição de Weimar, promulgada a 31 de julho de 1919, artigo 146, parágrafo 20: "a pedido dos pais ou tutores, fundar-seão escolas primárias de suas respectivas confissões ou opiniões filosóficas". Com pequenas variantes, legislações análogas possuem a Suécia, Noruega, Dinamarca, Áustria, Luxemburgo. ${ }^{39}$

Na Holanda, segundo Gastão Liberal, a lei que regia o ensino primário, promulgada em 1920, aprovada por 75 votos contra 3, isto é, pela quase unanimidade dos deputados, declarava que o ensino nacional compreendia dois tipos de escolas, umas abertas pelo governo onde o Ensino Religioso era facultativo e outras por iniciativa particular, mas mantidas pelo Estado e onde a associação particular que solicitou a abertura assistia o direito de dar a orientação espiritual em harmonia com suas crenças religiosas. Legislação semelhante existia na Bélgica, Inglaterra, na Hungria, na Tchecoslováquia, Grécia, Áustria, Bulgária e na lugoslávia. Por todos era sabido que na Polônia e na Itália a legislação favorecia e respeitava o Ensino Religioso.

\footnotetext{
${ }^{38}$ O Estado de S. Paulo. 02.01.1932

${ }^{39}$ O Estado de S. Paulo. 02.01.1932
} 
Não eram apenas os legisladores europeus que assim pensavam e procediam; também no Brasil, os expoentes da intelectualidade abraçaram a doutrina contra o ensino leigo na escola, citando o exemplo de Rui Barbosa, Pedro Lessa, Araújo Castro, Filinto Bastos, Pontes de Miranda, Antonio Carlos, Pandiá Calógeras e do ministro Francisco Campos que, na exposição de motivos da lei do ensino religioso escreveu que ao Estado cumpria respeitar o direito natural dos pais de dirigir a educação dos filhos, não impondo uma crença aos que a ela se não querem submeter, mas também não constrangendo a um ensino agnóstico ou filhos das famílias religiosas, cuja liberdade de consciência o Estado não podia violar. Para Gastão Liberal, o laicismo escolar, naquela altura, figurava um verdadeiro anacronismo. ${ }^{40}$

O religioso, em seu artigo-resposta, questionou se tantas autoridades mundiais julgavam necessário o Ensino Religioso, se todas as legislações consagram semelhante princípio, se as vantagens de sua adoção eram inegáveis, por que taxar de imprudente, julgar inoportuna a adoção do Ensino Religioso facultativo? Com relação ao perigo de conflitos graves na escola ele afirmou que a Alemanha, a Holanda e a Polônia eram países muito divididos religiosamente e não constava que alguém tivesse pedido a abolição do Ensino Religioso por este motivo. Nas escolas alemãs, para Gastão Liberal, alunos católicos e protestantes separavam-se para receber a instrução religiosa dos respectivos ministros religiosos e depois retomavam pacificamente a vida escolar. No sul do Brasil os ginásios oficiais eram confiados a religiosos, as aulas eram frequentadas por católicos e luteranos que lá contavam proporção mais elevada, o Ensino Religioso aqui se propala. Em S. Paulo, já se tinha feito um ensaio da adoção do Ensino Religioso nas escolas públicas e, embora praticado o regime apenas durante dois meses com sofreguidão acudiu a grande massa das crianças para a aula de religião católica, a única que se apresentou para gozar das vantagens da nova lei.

Gastão Liberal afirmou que nenhuma desordem houve e nenhum mal havia de se lamentar. Apareceram queixas e reclamações, mas nos 46 grupos da capital e em muitos do interior, não se havia concretizado um fato e toda a acusação ficou na pura generalidade. Esta circunstância já autorizava supor a

${ }^{40}$ O Estado de S. Paulo. 02.01.1932 
falsidade da acusação, mas o que se tinha alegado, mesmo em generalidade, foi categoricamente desmentido pelos fatos. Uma acusação que tem sido muito repetida é a que afirmava terem algumas professoras castigado os alunos que não aderiam ao Ensino Religioso, chegando mesmo a privá-los de recreio.

Foi tão grande a aceitação do Ensino Religioso entre os paulistas, de acordo com Liberal, que, de 1500 professores que constituíam o professorado da capital, 1200 espontaneamente se alistaram para o Ensino Religioso e este número ainda seria maior se, por certo escrúpulo, muitas outras que eram católicas, não se julgassem incapazes para presidir à aula de religião. Estes números eram reais, ele afirmava, e a respectiva relação de professoras foi apresentada a Diretoria Geral do Ensino e podia-se verificar da veracidade da asserção Cúria Metropolitana.

O futuro bispo de Campinas aproveitou para rebater as palavras atribuídas a Dom João Nery, classificando-se como infelizes. Aquelas palavras estão muito bem na boca de um bispo da Igreja Católica, que devia reconhecer a liberdade que a Constituição de 1891 trouxe para a Igreja, outrora agrilhoada pelas leis de exceção do regime monárquico. Mas daí não se podia concluir que aquele saudoso bispo fosse partidário da escola leiga. Seu modo de pensar era muito diverso. Na Pastoral Coletiva de 1915, subscrita pelo Sr. D. Nery ele expressara que os católicos não podiam defender nem aprovar o método de ensino e de educação leigo da juventude, que era separado da fé católica o da autoridade da Igreja. "Reprovamos o modo de pensar daqueles que afirmam ser necessário subtrair a educação da mocidade ao cuidado da Igreja". ${ }^{41}$

Finalizando, o religioso afirmou que no grande celeuma levantado contra o Ensino Religioso nas escolas públicas do Brasil, fazem causa comum ateus, maçons e protestantes. Embora discordando do modo de ver dos ateus, o futuro bispo reconhecia neles uma certa lógica: desconhecendo e negando o sobrenatural eram consequentes ao combater o Ensino Religioso. Quanto aos protestantes, se não se aproveitavam das vantagens da lei era porque não podiam ou não queriam. Na primeira hipótese, confessavam que não formavam

${ }^{41}$ O Estado de S. Paulo. 02.01.1932 
nenhum núcleo ponderável em meio da grande massa católica e, não podendo gozar daquela vantagem, procediam como uma das mulheres que figuravam na sentença de Salomão que não tendo mais seu filho, procurava a morte do filho de sua companheira.

Na segunda hipótese, se não queriam usar dos favores que concedia a lei do Ensino Religioso seria uma atitude inexplicável, pois, como diz a nota do Estado "é da índole de todo o crente, está na substância de toda Igreja, pregar as próprias doutrinas". Para lograr este ideal, em todos os tempos e lugares, como na Alemanha no tempo do Kulturkampf e na Holanda em 1880, membros de todos os credos unem-se para conseguir a liberdade, cada um a da sua religião. O protestante no Brasil, opunha-se violentamente à restauração nas escolas, ou não querendo gozar das vantagens que neste sentido a lei oferecia, constituía uma exceção incompreensível na história de todas as religiões. ${ }^{42}$

Em artigo seguinte, nova resposta ao religioso Monsenhor Gastão Liberal Pinto, que foi acusado de tirar as frases de Teixeira Mendes do contexto, o que levaria a supor uma possível defesa da religião nas escolas por parte do representante positivista. As críticas giravam em torno da educação infantil, dos cuidados familiares e à quem competia o Ensino Religioso. ${ }^{43}$

Em nova resposta, o Monsenhor Gastão Liberal Pinto afirmou que o ensino ministrado à criança tinha por fim dar ao cidadão do futuro, além das primeiras noções e conhecimentos humanos, os bons hábitos da virtude que habituam ao uso nobre das faculdades. Deveria ser uma prerrogativa da família e só subsidiariamente e na falta dos pais tão nobre missão cabia ao Estado, que seria um poder de governo e não um poder de ensino. Para o bem geral, o Estado pode intervir no ensino para afastar os incompetentes, para manter, estimular e elevar o nível dos estudos, para a mantença da ordem, garantir a saúde pública, mas deste oficio de proteger, animar, suprir e fazer as vezes não se conclui a prerrogativa exclusiva de ensinar.

\footnotetext{
${ }^{42}$ O Estado de São Paulo, 02.01.1932.

${ }^{43}$ O Estado de São Paulo, 07.01.1932.
} 
A escola fundada e mantida pelo Estado aparecia com o fim de corrigir as falhas da família, porque nem todas contavam com os recursos suficientes para a formação intelectual e moral dos próprios filhos, e então esta faculdade, que the competia subsidiariamente, deveria ser exercida sem prejuízo dos direitos da família. A função da escola pública devia ser completa.

E como fazê-lo sem a religião? Indagava o Monsenhor. "Escola neutra não existe" porque não havia professor sem opinião religiosa ou filosófica. Se ele não tivesse opinião, seria um ser fora da humanidade, é um monstro; e se tivesse opinião e a ocultasse por causa de um ordenado, seria o último dos covardes. $\mathrm{E}$ seu esforço seria em vão. Poderia cerrar os lábios, sua opinião havia de se manifestar nos olhos, nos gestos, em toda sua pessoa. Adotar e impor um credo equivalia a desrespeitar os direitos básicos dos pais que procuravam a escola para seus filhos não para destruir o que eles começaram a edificar, mas para desenvolver e consolidar os bons princípios que o desvelo paterno foi instilando, um a um na alma juvenil, habituada a respirar o ar sadio de que está saturado o lar doméstico.

Era tão sagrado este direito dos pais, concluiu Gastão Llberal que não se concebia pior tirania que tentar impor à criança. Incapaz de defesa e reação, credo diverso daquele haurido debaixo do teto da família. Era este um princípio tão evidente, verdade inconcussa que caía com freqüência da pena de qualquer escritor, por mais intenso que fosse seu espírito de facção e de sectarismo. ${ }^{44}$

Os protestos no início de 1932 continuavam seguindo pelas páginas do jornal O Estado de S. Paulo durante vários dias. Em mais um manifesto contra a proibição do ensino religioso nas escolas, o Centro $D$. Vital dirigiu um telegrama a Getúlio Vargas. Apresentando solene protesto "contra ato arbitrário, apaixonado e ilegal do interventor federal de São Paulo", desautorando governo provisório ao negar cumprimento ao benemérito decreto 30 de abril, que veio atender reclamos todas consciências religiosas brasileiras. "Confiantes no espírito reto de v. excia pedimos sua intervenção imediata a fim de ser restabelecida autoridade da lei

\footnotetext{
${ }^{44}$ O Estado de S. Paulo 08.01.1932.
} 
federal, tão evidentemente violada por esse decreto iníquo, violentador da consciência. Respeitosas saudações - Alceu Amoroso Lima”. ${ }^{45}$

Foi publicado o telegrama que o Dr. Amaro Silveira recebeu do coronel Manuel Rabello, interventor em São Paulo: “agradeço ao amigo as generosas expressões do vosso telegrama sobre meu veto proibindo ensino de religiões nas escolas públicas". Continuando o interventor afirmou: "Enquanto em mim estiver tudo farei pela fraternidade, procurando honrar memórias de Benjamin Constant, Júlio de Castilhos, Demétrio Ribeiro e tantos outros republicanos que trabalharam em prol da ordem e do progresso". Coronel Manuel Rabello, interventor federal. ${ }^{46}$

A decisão do interventor de São Paulo, como se observa, gerou muita polêmica no início do ano de 1932. A série de três livros do jornalista Lira Neto sobre Getúlio Vargas mostra uma boa apresentação do que foi o dia a dia do chefe do governo provisório, através de seus atos registrados em diários e notícias da imprensa. O autor narra a passagem de poder a Manuel Rabello e as razões de Vargas para tal indicação. Rabello não era civil, nem paulista, para Lira Neto. Fluminense, positivista ortodoxo, foi preso político por ter participado do levante tenentista de 1922. Foi reintegrado à caserna por decisão do Governo Provisório. Entre as providências imediatas como interventor, determinou que a mendicância deixasse de ser considerada caso de polícia e que os pedintes fossem tratados como quaisquer outros cidadãos, no gozo pleno de seus direitos. A medida foi ridicularizada pelas elites e classes médias do Estado, que o acusaram de querer incentivar a vagabundagem e transformar São Paulo na 'capital mundial dos mendigos'. Sua interinidade se estendeu por quatro meses não pela dificuldade de Getúlio encontrar quem quisesse assumir o cargo em definitivo e sim porque a questão era descobrir quem, uma vez escolhido, conseguiria realmente tomar posse e governar. "Se for legionário, os democráticos não aceitam. Se for democrático, os membros do PRP não aceitam. Se for membro do PRP, os revolucionários não aceitam. Ninguém serve resumiu Goés Monteiro". Getúlio Vargas tinha outra explicação para a estratégia de cozinhar o assunto em fogo brando. Mesmo pressionado, continuava fiel à

\footnotetext{
${ }^{45}$ O Estado de S. Paulo, 05.01.1932. pág 1.

${ }^{46}$ O Estado de S. Paulo, 06.01.1932. pág 1.
} 
característica de não apressar o curso dos acontecimentos. Em seu diário rabiscou: "resolvo deixar o coronel Rabello, para ganhar tempo e examinar melhor o tabuleiro. (...) Sinto que se aproximam momentos decisivos". Em 3 de março de 1932, Getúlio Vargas substituiu Manuel Rabello por um interventor que se enquadrava na fórmula "paulista e civil", Pedro de Toledo, que posteriormente foi líder paulista na Revolução Constitucionalista. ${ }^{47}$

A Associação de Professores Católicos do Distrito Federal também apresentou a Vargas um protesto, afirmando ferir a consciência religiosa da nação brasileira e que o veto era manifestamente ilegal perante o decreto de 30 de abril de 1931. "Confiamos na ação esclarecida de Vossa Excelência a fim de que cesse imediatamente a proibição injustificável e atentatória da autoridade de um decreto federal". ${ }^{48}$

O pensador católico Leonardo Van Acker fazia um contraponto às ideias do Centro Dom Vital, encarnadas por Alceu Amoroso Lima e Plínio Correa de Oliveira. Em artigo sobre tolerância e intolerância religiosa, Van Acker afirmava que se falava demais contra o ensino verbal, que a experiência demonstrava imprescindível à harmonia do comportamento social humano. "Exemplo frisante é o emprego das palavras 'tolerância' e 'intolerância', armas perigosas manejadas por muita gente que lhes não parece compreender alcance".

"Mas não leva a dita intolerância a comprometer a paz civil?", indagou o pensador. Os católicos viviam com liberais e comunistas, cujos princípios formalmente considerados ou abstraindo da parcela material de verdade importavam a dissolução da sociedade humana. Como então se poderia conceber a paz cívica entre homens divergentes sobre as bases sociais, mas concordando em ser necessário defendê-las? A convivência pacífica civil entre católicos e adversários radicais só seria possível, para Van Acker, enquanto os acatólicos

\footnotetext{
${ }^{47}$ NETO, Lira. Getúlio: do Governo Provisório à ditadura do Estado Novo (1930-1945). São Paulo: Companhia das Letras, 2013. pp. 73 a 76.

${ }^{48}$ O Estado de S. Paulo 09.01.1932.
} 
consentissem em defender na prática o que destruíam em teoria. O acordo cívico era devido, pois, a um ilogismo cuja durabilidade ninguém podia garantir. ${ }^{49}$

O mesmo autor refletiu sobre a separação entre Igreja e Estado, verdadeira fonte do conflito sobre o Ensino Religioso. Significativa a esse respeito é a nota publicada no Estado de São Paulo em 3 de janeiro de 1932: "somos contrários ao Ensino Religioso nas escolas públicas, não por sectarismo anti-religioso nem por desconhecermos o valor educativo das religiões, mas por ter mostrado a experiência não ser possível ministrá-lo nas escolas públicas sem perigo da confiança, agitações e ofensa à liberdade de consciência dos outros. Sigamos, pois, à risca o preceito constitucional de absoluta separação entre o que é leigo e o que é religioso. Se o Estado tivesse o monopólio do ensino, ainda se poderia admitir uma cadeira de religiões nas escolas públicas. Sendo, porém, livre o ensino, torna-se inadmissível essa medida quando não há acordo completo a esse respeito entre todas as confissões religiosas. Que o catolicismo seja a religião da maioria não vem ao caso. O essencial é a paz e para isso, a unanimidade. Que haja prejuízo moral para os alunos das escolas públicas é um menor mal, corrigido pelo ensino religioso nas escolas particulares e compensado pelo bem maior da separação, ao Estado conferido o dever de amparar todos os cultos e de prevenir atritos entre as várias confissões religiosas.

Há neste arrazoado que procuramos fielmente resumir, duas concepções contraditórias do princípio de separação entre Igreja e Estado. Se o preceito constitucional é de absoluta separação entre o que é leigo e o religioso, como pode ao Estado outorgar o direito e o dever de amparar todos os cultos e prevenir atritos entre as religiões? Se bem entendemos o português, amparar é suster, apoiar e não ficar alheio ou rigorosamente separado.

Demais, nenhuma das interpretações contraditórias é consoante ao princípio constitucional separatista. Se fosse deveras absoluta a separação entre o leigo e o religioso, inconcebível seria a liberdade pública dos cultos, ficando estes condenados a não ultrapassar os limites da família, da escola particular ou da Igreja. Por igual consequência não deveriam os cemitérios públicos admitir

\footnotetext{
${ }^{49}$ O Estado de S. Paulo. 24.01.1932.
} 
senão o enterro civil, ficando os cemitérios religiosos, rigorosamente separados, a cargo dos fiéis dos vários cultos, como atualmente o ensino religioso incumbe às escolas confessionais particulares. Se, por outro lado ao Estado assistisse o direito de amparar todos os cultos, em que ficaria a proibição de qualquer subvenção ou aliança, formulada no princípio constitucional que regula a separação?

Verdade é que o Estado tem o direito e dever comum de zelar pela paz e prevenir atritos ou agitações. Porém, a ele, mormente quando separado da Igreja só compete garantir a paz civil e não a harmonia religiosa que é da competência exclusiva de autoridades teológicas e eclesiásticas. O essencial é por certo a paz ou ordem pública, mas esta não exige unanimidade. As lutas religiosas como as partidárias políticas não constituem por via de regra infrações à paz civil. Lutas pacíficas, religiosas ou políticas, são manifestações de vitalidade e liberdade nas opiniões e cultos, a que deve o Estado plena e constitucional tolerância pública. E plena tolerância não se limita, já se vê, à imprensa ou ao cemitério, estendendose também à tribuna que não cabe apenas na rua mas também nas escolas públicas. Nem há razão para lamentar no meio dos educandos as lutas pacíficas de ideias e religiões. A escola deve educar para a tolerância e esta não se consegue fora do exercício da luta. Educação é vida segundo modernos como antigos. E por falarmos em educação: sabemos por experiência como, nos melhores colégios católicos, o ensino religioso sofre da influência das ideias leigas vigentes, por onde muito folgaríamos em aprender como a doutrinação religiosa particular poderia corrigir a carência de ensino religioso nas escolas públicas. Se os próprios alunos católicos já ouvem com prevenção os cursos de religião, qual será então a atitude dos discípulos educados no laicismo? Em tudo isso nem consideramos se é justo que os contribuintes crentes sejam obrigados a pagar uma escola particular para que os filhos adquiram um pouco de 'formação espiritual e fortalecimento de caráter'.

Deixemos, porém, da digressão pedagógica. O que mostra a experiência não é a impossibilidade do ensino religioso público nem agitações ofensivas à ordem pública. Do contrário, quereríamos alegados fatos concretos em vez de afirmações gerais e abstratas. A experiência geral mostra não ser possível 
centralizar na mesma escola pública o ensino de todos os credos sem provocar rivalidades e discussões religiosas, embora civilmente pacíficas.

Mas, tais competições fazem parte da liberdade pública de opinião e cultos, garantida pelo princípio separatista. Há, aliás, se quisermos, um meio eficaz de reduzir ao mínimo essas lutas: é criar, como na Alemanha, escolas públicas para as várias confissões, além das puramente leigas. Tal seria o perfeito liberalismo.

Dirá porventura alguém: Estamos de acordo. Queremos todas as opiniões respeitadas pelo Estado. Mas isso é impossível no caso. Concedido o ensino religioso, jubilam os católicos, protestam os protestantes, recusam os ateus! Facilmente retorquimos: nestas condições, nem com a supressão do ensino religioso torna-se mais viável o respeito a todas as opiniões, pois, contra essa levantam-se os católicos, com grande regozijo de ateus e protestantes. Acresce que nesta ultima hipótese os reclamantes são a maioria, não desprezível em teoria liberal. Finalmente, é de bom senso que o Estado não tem o dever de transgredir o próprio dever de tolerância pelo respeito a opiniões intolerantes. $O$ decreto do ensino religioso a todos facultou a instrução conforme convicções respectivas. A opinião católica declarou usar da liberdade outorgada sem impedir aos outros; ao passo que os adversários, recusando a faculdade concedida, se limitaram a combater, intolerantes, a opinião e liberdade alheia. Conceder, pois, à intolerância é ser por sua vez intolerante.

Fim essencial deste artigo não é responder à nota de $O$ Estado, senão que voltar à raiz das lutas atuais. É inegável que a Constituição é inspirada no bom senso prático quanto ao princípio da separação, à liberdade dos cultos e ao regime dos cemitérios. Mas igualmente manifesto é o espírito liberal maçônico nos dispositivos sobre o ensino público, o casamento civil e as incompatibilidades eleitorais e representativas. Daqui vem que autorizados e insuspeitos intérpretes, como Ruy Barbosa, Pedro Lessa, etc. logicamente explicam os corolários laicistas pela tolerância dos princípios de separação e liberdade dos cultos. Nem por isso deixa a constituição de ser perigosamente incoerente, de onde sempre haverá outros preferindo o método sofístico de torcer os princípios do sentido isolado de certos corolários. Não vem ao caso examinar se é oportuna a Constituinte. Mas, 
se esta se realizar, urgirá acabar com essa fonte de estéreis discussões e decidir entre a tolerância real ou aparente. Neste ponto, só desejamos ao povo brasileiro um momento de verdadeira liberdade e soberania para nas urnas manifestar o que sente e quer. (Leonardo Van Acker) ${ }^{50}$

Em 7 de julho de 1932, foi publicado no Estado de São Paulo o programa do Segundo Congresso do Centro Dom Vital que aconteceria no salão nobre da Cúria Metropolitana. Haveria palestras sobre o ensino leigo, casamento religioso com efeito civil, símbolos religiosos em repartições do país, relações entre Igreja e Estado na República, decreto do Ensino religioso. Entre os palestrantes estavam Leonardo Van Acker e Plínio Correa de Oliveira. ${ }^{51}$

Em outra edição, um artigo apresenta críticas e indiretas a Getúlio Vargas, citando como exemplo de bom funcionamento do ensino religioso o município de Piracaia, no interior de São Paulo, próximo a Atibaia. "Nos meios católicos, faz pouco, houve grande atordoada em torno do ensino religioso para a infância escolar. A celeuma aguçou a habilidade de certo político, que aliás antes se manifestara acérrimo paladino do ensino oficial leigo no seu Estado natal. E eis que logo a ditadura lançou aos quatro ventos um decreto que autorizou formalmente o ensino religioso facultativo nas escolas. Os meios católicos então desmancharam-se em salamaleques à ditadura, esquecidos de que as ditaduras com a mesma com que fazem favores, para deles tirar proveitos, logo no dia seguinte, para se tornarem agradáveis a outros que mais Ihes mereçam, os retiram, com o mesmo decoro, dando o dito por não dito. É da história e até característica das ditaduras, a volubilidade.

A nossa não seria exceção à regra geral. $E$, assim, os primeiros embates dos paladinos da escola anti-religiosa, e não da escola neutra - os católicos ingênuos verificaram o logro que se lhes havia impingido. Céus e terra foram abalados com seus protestos. A ditadura nem sequer se dignou de dizer-Ihes 0 porquê da sua nova resolução! Tudo e todos voltaram à 'última forma' talvez, continuando a esperar a realização de seus desejos por um gesto de

\footnotetext{
${ }^{50}$ O Estado de S. Paulo 10.01.1932.

${ }^{51}$ O Estado de S. Paulo 07.01.1932.
} 
magnanimidade do poder discricionário, quando melhor seria arregimentar forças para a rápida constitucionalização do país e para impor suas aspirações ao poder constituinte e para que, fora do horário oficial, por exemplo, meia hora depois os professores católicos pudessem reunir os alunos católicos, na mesma escola, para dar-Ihes o ensino religioso de conformidade com a vontade soberana das suas famílias.

Enquanto, na capital do Estado permanece esta situação indefinida, cheganos de Piracaia uma notícia gratíssima. Ali, uma só professora católica resolveu a situação sem matinadas e sem que ninguém tenha em que se apegar para reclamar da ditadura medidas de coação ao cumprimento de seus deveres de educadora e de católica.

A exma. Sra. D. Maria da Glória Cintra Bueno, professora da escola mista rural, na Fazenda Fortaleza, instituiu um curso noturno de religião para as crianças que livre e espontaneamente quisessem freqüentá-lo. Dada a índole religiosa do nosso povo, a freqüência foi animadora, pelo que aquela distinta professora resolveu preparar uma turma de crianças para fazer a primeira comunhão. A comovente festa eucarística teve lugar domingo, dia 12, véspera da festa do padroeiro da paróquia. Santo Antonio, na missa das 8 horas, celebrada pelo revmo. Sr. bispo de Bragança, fazendo-se ouvir, graciosamente a orquestra dirigida pela exma. Sra. D. Marieta Pestana. Finda a missa, foram oferecidos pela exma. Sra. D. Nhanhan Cunha em seu palacete, chá, café e leite aos comungantes, que receberam belíssimas lembranças.

É altamente consolador, nos tempos que correm, a iniciativa da esforçada professora, dedicando as suas horas de descanso na formação espiritual e religiosa das crianças que, sem as facilidades das cidades, podem aprender a fortaleza da alma emanada do Evangelho. Praza aos céus que todas as professoras rurais, afastadas dos centros, imitem a bela iniciativa desta distinta professora, no aparelhamento moral e religioso da infância, que lhes é confiada não apenas para ser instruída nas primeiras letras, mas, principalmente, para ser educada, isto é, para que se lhe formem coração e caráter, dotes bem superiores, 
para que se torne fator de grandeza da nacionalidade que os apuros literários sem base na cultura moral.

Quanto vale a ação enérgica e decisiva da opinião pública em contraste com a verbiagem inócua, o dia 23 de maio, um só dia, poucas horas, foi uma prova decisiva. Naquele dia se fez o que se não conseguira em dezesseis meses de discursos e de lamentações em voz baixa, entre amigos, a tremer de medo das carrancas da ditadura e de seus corifeus. Oxalá os dois exemplos, o da data memorável e o da decidida professora católica de Piracaia, despertem energia ao menos para que a ditadura se defina sobre este assunto, no qual a tapeação é intolerável, dizendo, de vez, se o seu decreto está de pé ou foi revogado por outro poder mais alto. (J. R.)

Na coluna 'Queixas e Reclamações' há reclamação de um cidadão por causa do funcionamento do Ensino Religioso em um Grupo Escolar da cidade: "como é do domínio público, o decreto que regulamentava o ensino religioso nas escolas públicas foi revogado pelo então interventor coronel Manuel Rabello, a fim de evitar lutas, odiosidades e abusos, que já se estavam verificando; pois bem, Sr. redator, imagine agora o meu espanto, quando soube com absoluta certeza que, no grupo escolar Regente Feijó, na avenida Tiradentes, por ordem do diretor, estão ensinando religião aos alunos dentro do período escolar." 52

Dom Leme sobre a Constituição de 1934. O cardeal D. Sebastião Leme baixou no dia 28 de fevereiro de 1934 uma circular fixando os pontos de vista da Igreja Católica em relação à nova Constituição. Pleiteava a decretação da Constituição em nome de Deus, a indissolubilidade do vínculo matrimonial, incorporação legal do ensino religioso facultativo nas escolas, assistência religiosa facultativa às classes armadas e sindicalização das sociedades católicas. ${ }^{53}$

\footnotetext{
52 O Estado de S. Paulo 07.04.1932.

${ }^{53}$ O Estado de S. Paulo. 01.03.1934.
} 
O 6ํㅡㄹ Congresso Nacional de Educação teve certo tumulto na sessão da noite de 9 de fevereiro de 1934 em que alguns delegados se exprimiram com exaltação, de acordo com o jornal. Após uma conferência realizada pelo padre Helder Câmara, muito aplaudida, o Sr. Cyro Vieira, delegado do Espírito Santo, sugeriu que o congresso enviasse um telegrama à Assembléia Nacional Constituinte, solicitando que seja incluída na carta magna da República o ensino religioso facultativo.

Imediatamente o Sr. Edgard Sussekind de Mendonça, representante da Associação Brasileira de Educação, declarou que queria protestar contra a traição e a deslealdade do Sr. Cyro que propusera coisa contrária ao regimento.

O representante da $A B E$ foi fortemente aparteado. Nessa altura, os ânimos se exaltaram a tal ponto que o interventor federal, capitão Carneiro de Mendonça, que se achava entre assistência, resolveu retirar-se.

As discussões prosseguiram ainda algum tempo, sendo, afinal, encerrada a sessão. ${ }^{54}$

Um editorial do grupo Folhas foi publicado no Estado meses depois da promulgação da Constituição de 1934. Segundo o artigo, durante os debates da Constituinte, as Folhas manifestaram-se contra o ensino religioso nas escolas, por entenderem que a religião da maioria do povo brasileiro mais lucraria com a conservação do atual regime, de abstenção por parte do Estado em tal matéria. $O$ temor do grupo Folha era que a inovação viesse a provocar atritos e choques que não se dão no Estado absolutamente leigo. "Entretanto, o ensino religioso venceu. Está consagrado hoje pela Constituição Federal. Aos estados não resta outro caminho senão regulamentá-lo, em obediência à lei fundamental.

É o que São Paulo acaba de fazer. Felizmente, no decreto estadual, a questão está posta com grande liberalidade. Nas escolas facultar-se-á aos alunos

${ }^{54}$ O Estado de S. Paulo. 13.02.1934 
o ensino religioso que seus pais preferirem. Não haverá, pois, privilégios em favor deste ou daquele credo.

Outro decreto que merece atenção é o que concede isenção de impostos a igrejas, capelas e outras instituições de caráter católico. Aí não houve inovação, pois que anualmente essas isenções são requeridas e concedidas desde velhos tempos. Apenas, tornou-se de direito uma situação de fato.

Entretanto, a mesma medida, pelas mesmas razões, deveria ser estendida a templos e instituições idênticas dos demais credos religiosos. A esse respeito, há geral boa vontade. E só daqui cuidamos de reforçá-la, apelando para o Sr. interventor interino, no sentido de examinar o caso de maneira a, ampliando o decreto publicado, atender nesse ponto às aspirações de outros credos que não o católico.

Tratando-se de uma medida de ordem geral que não contenha privilégios nem exceções, terá um caráter de justiça a que ninguém poderá recusar o seu louvor. ${ }^{55}$

\section{Culto católico}

"Que escola admirável, a de São Paulo e a dos santos da Igreja, para a formação dos caracteres e para que, na humanidade inteira, a beleza moral fosse a regra geral ao invés de ser a raríssima exceção de nossos dias de agnosticismo e de utilitarismo corruptores. (...) Da outra escola saem os egoístas, os gozadores da vida, os opressores dos humildes e dos pequenos; os que fogem dos pobres e dos enfermos; os duros de coração e débeis de caráter; os oportunistas, a serviço de tudo que the proporcione lucros e vantagens; os servis e os traidores; os maus e dissolutos e também até os grandes criminosos. (...) Para o mundo cego espiritual, o sol que ele não vê é Jesus Cristo, são as manifestações sublimes da fé cristã na ordem social, e na fraternidade humana. Não menos surpreendente a sua contradição, confessam sua admiração e seus louvores aos gestos nobres e

${ }^{55}$ O Estado de S. Paulo. 13.10 .1934 
beneméritos, das almas iluminadas pela fé, das almas educadas na escola cristã e, entretanto, detratam a fé, menosprezam e ridicularizam a religião; querem banir da educação da infância o ensino religioso e do mundo o império de Jesus Cristo. 56

Programa da Liga Eleitoral Católica

O secretário geral da Liga Eleitoral Católica, Sr. Alceu Amoroso Lima, divulgou os dez princípios de justiça legal e distributiva, que constitui os lemas fundamentais de ação da liga e o seu programa:

1ํPromulgação da Constituição em nome de Deus.

2ํㅡㄹ Defa da indissolubilidade do laço matrimonial.

3 Incorporação legal do ensino religioso facultativo nos programas das escolas públicas primárias, secundárias e normais da União, dos Estados e dos municípios;

4ํㅡㄹ Regulamentação da assistência religiosa facultativa às classes armadas, prisões, hospitais, etc.

5 Liberdade de sindicalização, de modo que os sindicatos operários católicos, legalmente organizados, tenham as mesmas garantias dos sindicatos neutros.

6ํㅡㄹ Reconhecimento do serviço eclesiástico, de assistência espiritual às forças armadas e às populações civis, como equivalentes ao serviço militar.

7ํㅡㄹ Decretação de legislação do trabalho, inspirada nos preceitos da justiça social e nos princípios da ordem cristã.

$8^{\circ}$ Defesa dos direitos e deveres da propriedade individual.

${ }^{56}$ O Estado de S. Paulo. 16.07.1933 
9o Decretação de lei de garantia da ordem social contra quaisquer atividades subversivas, respeitadas as exigências das legítimas liberdades políticas e civis.

$10^{\circ}$ Combate a toda e qualquer legislação que contrarie, expressa ou implicitamente, os princípios fundamentais da doutrina católica. ${ }^{57}$

Logo após a promulgação da Constituição, em 16 de julho de 1934, foi fundado em Sorocaba o Sindicato Católico do Professorado Sorocabano, instituição que tinha por objetivo "reunir seus membros duas vezes por semana e nos dias das sessões pedagógicas mensais, a fim de instruí-los relativamente às aulas de ensino religioso que deverão dar dentro do horário escolar, logo que seja regulamentada a nova Constituição. Além disso, promoverá a sociedade aulas aos regentes das escolas rurais. A diretoria convidará para a aula inaugural o $\mathrm{Sr}$. d. José Carlos, bispo diocesano, e para as que se Ihes seguirem, os srs. Cônego Francisco Cangro, padre Luiz Castanho de Almeida e os sacerdotes beneditinos d. Rosendo, d. Maynulpho e d. Walfredo." 58

No dia $1^{\circ}$ de novembro de 1934, São Paulo recebeu a visita do patriarca de Lisboa, o cardeal d. Manuel Gonçalves Cerejeira. Sua passagem pela capital e interior receberam grande destaque do jornal O Estado de S. Paulo. Após a missa e visitas pela cidade, o religioso fez um pronunciamento de quarenta minutos, principiando por agradecer o comparecimento dos membros de governo do Estado e felicitando-os em seguida pela assinatura do recente decreto que instituiu o ensino religioso. ${ }^{59}$

Assembléia Nacional Constituinte: os trabalhos da 40ª sessão ordinária

"A sessão de hoje da Assembléia Nacional Constituinte foi iniciada com a presença de 103 deputados. Aprovada a ata, foi dada a palavra ao Sr. Arruda Câmara, que trata do ensino religioso facultativo nas escolas. $O$ orador manteve-

\footnotetext{
${ }^{57}$ O Estado de S. Paulo. 14.03.1933.

${ }^{58}$ O Estado de S. Paulo. 01.08.1934.

${ }^{59}$ O Estado de S. Paulo. 02.11.1934
} 
se por longo tempo na tribuna, defendendo o dispositivo que, no anteprojeto da Constituição, cuida da matéria. 60

A Coligação Nacional Pró-Estado Leigo realizaram-se no Rio de Janeiro diversas solenidades em comemoração à data da promulgação da Constituição de 1891. No dia seguinte, realizar-se-iam nas igrejas evangélicas e em associações diversas prédicas e conferências sobre a laicidade do Estado e combatendo o ensino religioso nas escolas, a assistência religiosa nos quartéis e a indissolubilidade do casamento. ${ }^{61}$

O jornal paulista publicou a sessão da Assembléia Nacional Constituinte que aprovou os dispositivos sobre o ensino religioso, no dia 30 de maio de 1934. "Anunciada a ordem do dia, o presidente comunica o prosseguimento da votação do destaque (...) do artigo $10^{\circ}$ do parecer da sub-comissão para ser aprovado, em seu lugar, o artigo $171^{\circ}$ do substitutivo que estabelece que o ensino religioso será de preferência facultativo e ministrado de acordo com os princípios da confissão religiosa do aluno, manifestada pelos pais e responsáveis, constituindo matéria do horário das escolas públicas primárias e secundárias, profissionais e normais. Falaram, encaminhando a votação, os srs. Villas Boas e Vasco de Toledo, contrários, Fernando Magalhães, favorável, Edgard Sanchez contrário, Arruda Câmara favorável e outro, sendo finalmente o substitutivo aprovado. O Sr. Fernando de Abreu pede verificação, verificando que 171 deputados votaram favoravelmente e 58 contra. 62

\section{DECRETO N. 6.766, DE 11 DE OUTUBRO DE 1934}

Incorpora ao regime escolar dos estabelecimentos oficiais de ensino primário, secundário, profissional e normal, o ensino religioso e estabelece outras providencias.

O DOUTOR MARCIO PEREIRA MUNHOZ, Interventor Federal interino no Estado de São Paulo, usando das atribuições que the são conferidas pelo decreto federal n. ${ }^{\circ}$ 19.398, de 11 de novembro de 1930, considerando que o artigo 153 da Constituição Federal admitiu o ensino religioso, de frequencia facultativa, ministrado de acordo com os princípios da confissão religiosa do aluno, manifestada pelos pais ou responsáveis,

\footnotetext{
${ }^{60}$ O Estado de S. Paulo. 04.01.1934

${ }^{61}$ O Estado de S. Paulo. 25.02.1934. pág. 1. Comemoração da primeira Constituinte republicana.

${ }^{62}$ O Estado de S. Paulo. 31.05.1934. pág. 1. Assembléia Nacional Constituinte
} 
constituindo matéria dos horários nas escolas publicas, primarias, secundarias, profissionais e normais; considerando a necessidade de regulamentar esse dispositivo constitucional, para ser aplicado nos estabelecimento de ensino oficial, Decreta:

Artigo 1. - Fica incorporado ao regime escolar dos estabelecimentos oficiais de ensino primário, secundário, profissional e normal, o ensino religioso.

Artigo 2. - O pedido de matrícula de alunos que tenham de receber ensino religioso nesses estabelecimentos deve vir acompanhado de documento assinado pelo pai ou responsável, declarando qual a confissão religiosa e cujos princípios deseja sejam ministrados a seu filho ou tutelado.

Artigo 3. - O ensino religioso será ministrado uma vez por semana, na segunda hora da aula, cabendo a organização dos programas e a escolha dos livros de texto aos ministros do respectivo culto. Artigo 4. - No inicio do ano letivo, o diretor do estabelecimento ou professor de escola isolada solicitará, das autoridades dos culto pretendidos pelos alunos, a designação do respectivo professor. § 1. - Feita essa designação, será determinado pelo diretor ou professor de escola isolada, dia e hora da semana para a aula de ensino religioso, sendo designados dia e hora diferentes para confissões diversas. § 2.․ - E' livre aos professores do Estado lecionar matéria religiosa, nos termos deste decreto, uma vez que sejam designados por quem de direito.

Artigo 5. - A inspeção e vigilância do ensino religioso pertencem ao Estado, no que respeita á disciplina escolar e ás autordades do culto a que se referir, no que respeita á doutrina e moral dos alunos e encarregados desse ensino.

Artigo 6. - Não é permitido aos professores de outras disciplinas impugnar os ensinamentos religiosos ou, de qualquer modo, ofender os direitos dos alunos que the são confiados assim como não é dado aos encarregados do ensino religioso provocar debates entre si ou entre alunos de confissões diversas.

Artigo 7. - Aos professores de Estado é expressamente proibido fazer dentro das escolas, propaganda de qualquer credo religioso, no sentido de influir-se seus alunos aceitem o ensino da doutrina ou do culto que professam.

Parágrafo único - Em nenhuma escola oficial será permitida, durante as aulas comuns, a existência de símbolos de qualquer culto, e bem assim a distribuição de folhetos ou impressos de propaganda religiosa. Artigo 8.․ - Qualquer duvida que possa surgir a respeito da interpretação deste decreto deverá ser resolvida de comum acordo, entre as autoridades civis e religiosas, a fim de dar á consciência das famílias todas as garantias de autenticidade e segurança do ensino religioso ministrado nas escolas oficiais.

Artigo 9. - Este decreto entrará em vigor na data de sua publicação, revogadas as disposições em contrario. Palácio do Governo do Estado de São Paulo, aos 11 de outubro de 1934. MARCIO PEREIRA MUNHOZ, Adalberto Bueno Netto.

Publicado na Secretaria de Estado da Educação e da Saúde Publica, em 11 de outubro de 1934. 
A Aliança Nacional Libertadora por meio de seu Comitê da Frente Única Popular contra o Imperialismo e o Integralismo protestou veementemente contra a dita "covardia da maioria dessa Câmara, votando a lei infame e reacionária e retrógrada do ensino religioso" e comunicou que a combateria energicamente, inclusive concitando o governador Pedro Ernesto ${ }^{63}$ a vetá-la em nome dos princípios da democracia social. ${ }^{64}$

Plínio Correa de Oliveira em artigos no Legionário sobre o decreto do ensino religioso: É com o coração transbordando de alegria que recebemos o decreto instituindo o ensino religioso nas escolas públicas brasileiras. Os próprios ataques que a insensatez dos laicistas tem arremessado contra o ato do Ministro Francisco Campos denotam que o agnosticismo, vitorioso em 1891, não passa hoje de doutrina desacreditada, pobre em argumentos e em adeptos, e vigorosamente rejeitada pela imensa maioria da nação brasileira.

Não compreendo como se possa ser, ainda hoje, agnosticista sincero.

Se não bastassem as fragorosas derrotas que tem sofrido no campo científico a famosa moral leiga, se não fossem suficientes os numerosos repúdios que tal doutrina tem sofrido de seus próprios partidários, o exemplo, o triste e doloroso exemplo do Brasil hodierno seria suficiente para evidenciar o que de falso, o que de cruel se encerra nas vãs ideologias do agnosticismo.

O espetáculo que atualmente oferece 0 Brasil, pobre país que se examina a si próprio com pavor, assustado pela deficiência de caráter de tantos de seus filhos; a incerteza angustiosa que se lê em todos os olhares, que procuram por todo o País, ansiosamente, elementos numerosos, fortes e moralizados que sejam capazes de fornecer ao país os enormes contingentes

\footnotetext{
${ }^{63}$ Prefeito do Distrito Federal entre 30 de setembro de 1931 e 2 de outubro de 1934 e entre 7 de abril de 1935 e 5 de abril de 1936.

${ }^{64}$ Correio Paulistano 28.05.1935.
} 
para o imenso exército de funcionários honestos de que precisa para viver; a instabilidade da nação, que oscila até em seus mais profundos fundamentos; e a causa de todos estes males, isto é, uma crise de caráter tremenda, deveriam constituir para os agnosticistas impenitentes uma prova suficiente do absoluto fracasso da moral leiga.

Logo que a vitória dos cristãos abriu para a humanidade o frasco de essências morais preciosíssimas que é a Igreja Católica, o bom odor das virtudes evangélicas se começou a alastrar dia a dia pelo mundo, vencendo o cheiro acre da barbárie franca ou germânica, e as exalações insalubres da civilização romana, já então em franca decomposição. E o bálsamo da sabedoria evangélica, fundindo raças, erguendo nações, foi a seiva fecundíssima que alimentou e fez crescer uma nova e magnífica civilização.

Só agora, porém, quando a civilização ameaça ruína, é que sentimos, num terrível despertar, a falta das virtudes católicas que aromatizavam amenamente a vida de nossos maiores; agora, que o americanismo cinematográfico invadiu, como onda de lodo, a família, o clube, as escolas e a sociedade, começamos a perceber que desapareceu completamente aquela doce honestidade de nossos avós; que nossos chefes de família não são mais o patriarca venerável de outrora, mas apenas o mais velho dos companheiros de "rapaziadas" de seus filhos; que as mães das últimas gerações já não são, em geral, os anjos de dedicação e amor que a Providência colocava como protetora de nossos berços, mas sim educadoras implacáveis e indiferentes de seus filhos, aos quais querem sacrificar a menor parcela possível de suas comodidades e gozos pessoais; que os filhos só vêem nos pais meros administradores da fortuna, e nas mães simples governantes de casa que se arrogam atribuições julgadas verdadeiramente desmedidas, que é preciso, a todo o custo, restringir; que a Pátria nada mais é do que um aglomerado de cidades que o acaso agrupou sob uma mesma autoridade política, e que as vantagens financeiras ou outras poderão, a qualquer momento, desagregar sem inconveniente algum de ordem moral; que a humanidade, enfim, é constituída exclusivamente por concorrentes nocivos do uso e gozo da natureza, que é necessário, a todo o custo, afastar como vizinhos incômodos e demasiadamente numerosos. 
Ora, com o predomínio de tais princípios, que sociedade pode viver? Que país pode ser honesto na administração pública, quando não existe patriotismo corajoso na guerra, quando não existe idealismo exemplar na família, quando filhos e pais nada mais são do que indivíduos que se disputam as partes mais aproveitáveis do patrimônio comum?

E agora mudem-se os quadros. Suponha-se um país em que, desde o chefe da nação até o mais modesto contínuo, desde o pai até os filhos, desde o patrão até os operários, predomine a prática rigorosa dos princípios católicos.

E imediatamente surgirão, a nossos olhos, estadistas abnegados e diligentes, funcionários probos e esforçados, pais moralizados e respeitáveis, generais valentes e disciplinados, filhos obedientes e amorosos, mães dedicadas e respeitadas.

Comunismo ou Catolicismo, eis o dilema a que não se pode fugir. Ou a dissolução atual continua sua marcha, e nos arrasta ao comunismo pelo apodrecimento de toda a organização política e social do país, ou voltamos atrás e, recorrendo à seiva do Catolicismo, que já uma vez salvou uma civilização que também estava podre, pomos Deus nas escolas, nas constituições, nos lares, nos clubes e principalmente nos caracteres.

Pelos frutos se conhecem as árvores. Compare-se o fruto amaríssimo da fase de agnosticismo que atravessamos, com o fruto dulcíssimo, cheio de suavidade, de uma nação radicalmente católica. E quem tiver a coragem de optar ainda pelo agnosticismo, que tenha ao menos a hombridade de defender também suas funestas conseqüências!! Que não nos fale em moral leiga, mas sim em imoralidade leiga.

Por isto, felicitamos calorosamente ao Dr. Francisco Campos e ao Governo Provisório, que com um simples decreto acabam de encerrar o período mais triste de nossa História. E que o Dr. Francisco Campos seja indiferente a seus inimigos. 
O característico dos grandes homens é de suscitar, simultaneamente, amizades ardentes e ódios implacáveis. Porque todo homem de bem, além da amizade fervorosa dos bons, tem de lutar contra o ódio rancoroso dos maus.

Felicitamos, portanto, o Dr. Francisco Campos, pelos inimigos que acaba de adquirir, assegurando-lhe também que seus amigos saberão ser, se necessário, tão ou mais implacáveis que seus próprios inimigos. ${ }^{65}$

"O Século", 3 de janeiro de 1932

\section{A Nota da Semana}

A Nota da Semana não poderia deixar de se ocupar do desastrado acontecimento que há dias atrás veio trazer mais um golpe profundo aos sentimentos religiosos dos paulistas.

Um militar que, a título interino, ocupava a interventoria à qual foi elevado por uma mera casualidade, que o colocou em uma evidência com a qual nunca sonhara, julga-se no direito de perturbar profundamente a paz religiosa do Estado, para impor aos católicos paulistas seus pontos de vista de acanhado sectarismo, com o rótulo de liberdade de consciência!

Muito barulho levantou o célebre decreto sobre a mendicância, em que o Interventor, estribando-se em alegações absurdas, revogou o próprio Código Penal.

Não the fica atrás seu último decreto sobre o ensino religioso, no qual os

princípios mais elementares do Direito são abertamente violados. É certo que a função de regulamentar os decretos federais cabe ao Interventor. Nestas condições, poderia S. Exa. ter modificado o decreto do Dr. Lando de Camargo, como bem lhe parecesse.

\footnotetext{
${ }^{65}$ O Legionário. 10 de maio de 1931. no 79. Disponível em http://www.pliniocorreadeoliveira.info/LEG310510_OtriunfodeCristo.htm\#.V5X54PkrLIU
} 
Nunca poderia, porém, negar toda e qualquer regulamentação ao decreto federal que institui o ensino religioso no Brasil, porquanto isto importa em negar pura e simplesmente aplicação a um decreto promulgado pelo Governo Federal, para vigorar em todo o Brasil.

Exorbitou, portanto, evidentemente, o Sr. Interventor de suas funções, e com isto pôs implicitamente em cheque o próprio sistema federativo.

Efetivamente, o decreto ataca a unidade do Brasil sob dois pontos de vista fundamentais: 1) visa quebrar a unidade religiosa, elo poderosíssimo que liga de norte a sul todos os nossos Estados numa admirável comunhão de ideias; 2) quebra a unidade legislativa da nação, negando a um Estado os benefícios que a todos os outros se concedem.

Contra um tal abuso da autoridade, por parte de um funcionário federal, cabia recurso ao Chefe do Governo Provisório. Usando de seus direitos de Pastor e Chefe, o Exmo. e Revmo. Sr. Arcebispo Metropolitano telegrafou ao supremo magistrado da nação, pedindo-lhe que restabelecesse entre nós a justiça e o direito violados.

Temos o direito de esperar do Governo Provisório medidas prontas e eficazes, que forçosamente se impõem como necessárias, ao "espírito jurídico" do Sr. Maurício Cardoso, Ministro da Justiça.

Devemos, no entanto, confessar que tais medidas já se estão fazendo esperar há diversos dias.

Trairá o Governo Provisório sua alta missão de mantenedor da unidade nacional, negando ao povo paulista a justiça que a altos brados reclama? Levará ele a preocupação política a ponto de abandonar seus mais sagrados deveres?

Só o futuro o dirá. Esperemos... sem esperança.

Outro disparate do Sr. Interventor Federal se encontra no curioso telegrama que passou ao Bispo de Campinas, e no qual repetia uma afirmação já feita em telegrama anterior ao Abade do Mosteiro de S. Bento: fora a Igreja, na 
Idade Média, quem estabelecera o regime da separação entre o Poder Espiritual e o Poder Temporal.

Esta afirmação foi haurida em Augusto Comte. Nem por isto é verdadeira.

De fato, a imensa maioria das nações antigas não fazia distinção alguma entre o Poder Temporal e o Espiritual. Ora era a Igreja que dominava o Estado teocratizado, ora era o Estado que reduzia à mais humilhante vassalagem o Poder Espiritual.

A Igreja, na Idade Média, estabeleceu uma distinção entre os dois poderes, colocando cada qual na sua esfera de ação peculiar, investido na necessária independência, mas, ao mesmo tempo, colaborando estreitamente um com o outro, como exige a própria natureza das respectivas funções.

Nem o Estado era teocrático, nem a Igreja era um mero departamento da administração pública. Igreja e Estado, porém, apoiando-se reciprocamente, colaboravam em estreitíssima união, para a consecução de seus respectivos ideais.

Entre esta situação e o agnosticismo absurdo do Sr. Interventor, contra o qual se levantavam a indignação e cultura de Teixeira Mendes, chefe da Igreja Positivista do Brasil, há um abismo imenso, que só o sectarismo do Sr. Interventor poderia transpor. ${ }^{66}$

"O Século", domingo, 20 de março de 1932

\section{A Nota da Semana}

É curioso o concerto de elogios, partido de todos os arraiais anticatólicos, desde o ateísmo até o protestantismo passando pelo positivismo, que se ergue agora em honra do ex-interventor, Cel. Rabello.

\footnotetext{
${ }^{66}$ O Século, 3 de janeiro de 1932. Editorial de Plínio Correa de Oliveira.
} 
Tais elogios, ditados evidentemente pelo sectarismo anticatólico, encontram sua expressão mais significativa na entrevista concedida pelo Sr. Maurício Cardoso, e em um artigo do Sr. João Ribeiro, no "Estado de S. Paulo", de 4ª feira p.p.

Exaltam ambos a "tolerância" do ex-interventor positivista. Ora esta tolerância, que, por razões provavelmente políticas, se manifestou em relação às competições partidárias, faltou inteiramente ao ex-interventor, no tocante ao problema religioso.

E estranhamos apenas que a "formação jurídica" do espírito do Sr. Maurício Cardoso não tenha levado S. Exa. a censurar a intolerância intratável do decreto positivista com que o Cel. Rabello revogou o ensino religioso, exorbitando de seus poderes de Interventor, e insurgindo-se, assim, muito injuridicamente, contra uma das poucas normas constitucionais, conservadas pela Revolução, de que ainda restam vestígios entre nós.

O Sr. João Ribeiro, por sua vez, depois de tecer comentários elogiosos à "tolerância" do ex-interventor, atribui a manifesta impopularidade em que este caiu ao ato "humanitário" com que aboliu a regulamentação da mendicância.

S. S. parece ignorar que a impopularidade do decreto não proveio do cunho humanitário que procurava ostentar, mas do indisfarçável ridículo de seus numerosos "considerando". Tal decreto, que foi transcrito na íntegra, e sem comentários, pela "Manhã", do Rio de Janeiro, valeu ao ex-interventor sua inclusão imediata no quadro de colaboradores do espirituoso periódico de Apporely. O Cel. Rabello absolutamente não foi, portanto, uma vítima inocente de seu humanitarismo que teria chocado os corações maldosos, mas o alvo de um ridículo merecido com que a opinião pública punha sua incompetência para 0 exercício das funções a que o guindara o acaso dos sucessos políticos.

Aliás, não foi somente em relação à mendicância, que tal incompetência se manifestou. Não compreendemos, por exemplo, como poderia um governo esclarecido restaurar a ridícula saudação "saúde e fraternidade", tradução errônea do "salut et fraternité" francês, cujo significado real é em bom português "saudação e fraternidade". Este deplorável erro de tradução, que acarretaria, para 
um ginasiano, uma reprovação implacável, encontrou, graças ao republicanismo rubro do ex-interventor, acolhida em nossos documentos oficiais.

É interessante que, em seu artigo afirma o Sr. Ribeiro que o ex-interventor não tem espírito sectário, pois que adota o livre-pensamento.

Ao que suponho, o Sr. João Ribeiro também é livre-pensador. Ora S. S. incorre em evidente sectarismo, quando entende que, para não ter espírito sectário, é necessário pensar como S. S. Já por aí pode o ilustre escritor verificar que também o livre pensamento produz alguns "espíritos sectários" dos quais S. S. é um.

Aliás, é ainda mais manifesto o espírito sectário de S. S. quando, no "in Memoriam" de Jackson de Figueiredo (Edição do Centro D. Vital, pág. 274) declara francamente que esperava vê-lo (Jackson) com o correr dos anos desenganado, envelhecido e descrente de seus esforços.

Eis aí uma esperança que trai um sectarismo inclemente. E é bem inútil tecer loas ao humanitarismo do Cel. Rabello, quando se deseja ver os adversários mergulhados na mais profunda aflição espiritual.

Quem sentiu, jamais, soprar sobre a alma um ardente ideal, quem se deixou empolgar, alguma vez, de todo o coração e de toda a alma, por uma grande aspiração doutrinária, quem já se entregou, ainda que por pouco tempo, à luta constante por uma ideia, não pode desejar a alguém maior desventura, do que o tremendo anoitecer do espírito, que se produz com o murchar das ilusões, com a extinção total da chama de todo o idealismo mergulhando a pessoa no "desengano" e na "descrença de seus esforços" que encheram toda uma vida, e isto principalmente quando a velhice, com seu progresso inexorável, repete ao homem, a cada instante, seu sinistro memento homo.

Militamos em campo religioso inteiramente oposto ao de S. S. Desejaríamos certamente que, em sua inteligência privilegiada, se substituísse às suas atuais ideias filosóficas a chama brilhante do ideal da Fé. 
Desejamos, é certo, de todo o coração que, no espírito de S. S., a um ideal que reputamos falso, suceda um ideal verdadeiro.

Nunca quereríamos, porém, que em seu espírito se apagasse todo e qualquer idealismo, puro e elevado, entregando sua alma, desamparada de qualquer proteção espiritual, à amargura íntima do ceticismo.

Por esta razão, reputamos inconcebivelmente sectário, tremendamente intolerante, o desejo que o espírito "livre-pensador" de S. S. formulou em relação a Jackson de Figueiredo.

Medico, cura te ipsum, deveríamos dizer a S. S., quando, no seu sectarismo, nos julga sectários simplesmente por sermos católicos, e absolve in limine o Cel. Rabello, simplesmente por ser da seita de S. S. ${ }^{67}$

No final de 1945, novas eleições já estavam sendo organizadas e a Liga Eleitoral Católica (LEC) voltou a se constituir e atuar junto a políticos pela manutenção das leis favoráveis à Igreja Católica. Na edição de 16 de outubro de 1945 o Estado de S. Paulo publicou: "A Liga Eleitoral Católica remeterá esta semana aos partidos políticos e a cada candidato a título de consulta um decálogo reivindicatório. Dos dez pontos já divulgados, a LEC, cuja circular será subscrita pelo embaixador Hildebrando Acioli, presidente, e professor Alceu Amoroso Lima, secretário geral, se manterá irredutível em relação ao $3^{\circ}, 4^{\circ}, 5^{\circ} \mathrm{e}$ 9o itens, que se referem ao seguinte: casamento indissolúvel e família amparada; ensino religioso facultativo nas escolas públicas; legislação trabalhista inspirada nos mais amplos preceitos da justiça social; assistência religiosa facultativa às classes armadas, prisões, hospitais, com o reconhecimento do serviço eclesiástico às forças armadas como equivalente de serviço militar. ${ }^{68}$

Resposta do Partido Social Democrático à consulta que the endereçou a Liga Eleitoral Católica: "Temos o prazer de acusar o recebimento do ofício, datado de 20 de outubro de 1945, no qual, esclarecido inicialmente que a Liga eleitoral

\footnotetext{
${ }^{67}$ O Século, domingo, 20 de março de 1932. Editorial de Plínio Correa de Oliveira.

${ }^{68}$ O Estado de S. Paulo. 16.10.1945.
} 
Católica é entidade extra-partidária e não tem candidatos próprios, solicitam v.v. Exas o nosso pronunciamento sobre o programa da mesma Liga, concretizado em quatro pontos mínimos, de cuja aceitação fica pendente a recomendação do Partido e a de seus candidatos ao eleitorado católico, no próximo pleito de 2 de dezembro deste ano.

Em resposta, cumpre-nos, desde logo, informar que o Partido Social Democrático, seção de São Paulo, muito apraz dar seu pronunciamento sobre todos esses quatro pontos. Efetivamente, três deles figuram, de modo expresso no seu programa. A indissolubilidade do laço matrimonial vem enunciada no capítulo da Organização social, sendo que a proteção às famílias numerosas também está compreendida assim na defesa da instituição da família o que se não entende logicamente sem a proteção às numerosas, como na clara referência à legislação brasileira, que consagrou em diferentes dispositivos legais, inclusive nos que criaram e desenvolveram o Instituo do abono familiar. Nesse mesmo capítulo da Organização Social, postula-se a garantia de salário mínimo que proporcione meios indispensáveis à vida digna entendido aquele mínimo no sentido assim de salário individual como de salário-família, bem como o estabelecimento deste último salário para os funcionários públicos, o que tudo são outras tantas modalidades de proteção às famílias numerosas.

O segundo ponto mínimo do programa da LEC, que é a incorporação legal do ensino religioso facultativo nos programas e horários dos estabelecimentos oficiais de ensino está explicitamente inscrito, cabendo lembrar que o Interventor Fernando Costa, presidente do partido, em São Paulo e seu candidato a governador no próximo período, jamais deixou de facilitar e propiciar amplamente o ensino religioso nas escolas oficiais, na forma da legislação que encontrou. 69

Publicação da Liga Eleitoral Católica dirigida ao eleitorado católico em 18 de novembro de 1945: "Aproxima-se o dia em que o nosso povo, pelo voto, vai escolher os seus mais altos representantes conferindo-lhes poderes para traçarem o roteiro constitucional da Nação. Incumbe, portanto, à Liga Eleitoral Católica, órgão destinado pela hierarquia da Igreja para arregimentar o eleitorado cristão, a tarefa indeclinável de agir, doutrinária e praticamente, junto à grande maioria dos brasileiros.

\footnotetext{
${ }^{69}$ O Estado de S. Paulo. 17.11.1945.
} 
De toda parte, aliás, convergem para a LEC manifestações de apoio e pedidos de esclarecimentos, reveladores da nítida compreensão dos graves problemas atuais por parte do povo.

A LEC situa-se para acima dos interesses meramente partidários. Não tem candidatos próprios. Não visa triunfos pessoais ou de grupos, mas a vitória de ideais. E é neste sentido que ela vem atuando, de modo eficiente, em seu contato com os partidos políticos.

Para isto, examinou, preliminarmente, os respectivos programas e estatutos. E com exclusão daquelas agremiações cujos objetivos já impliquem numa hostilidade aos princípios da própria LEC ou num apoio a doutrinas formalmente condenadas pela Igreja, a todas as mais enviou uma consulta.

Nesta,, redigida em termos sempre idênticos, indagou, de modo especificado, qual a posição do partido, em face das aspirações católicas já consubstanciadas no Decálogo amplamente divulgado.

Bate-se a LEC pela adoção integral desse programa. Todavia, propôs a todos os partidos um conjunto de pontos mínimos, cuja incorporação às futuras leis fundamentais é considerada desde logo imprescindível.

Destarte, a Liga Eleitoral Católica desaprovará o voto nos partidos que se neguem a defender, pelo menos, essas reivindicações básicas.

Tais pontos mínimos reafirmam, de um lado, os imperativos da consciência católica do povo brasileiro, expressos na campanha de 1934 e, de outro, asseguram largo avanço no sentido do bem comum através de nova exigência, a de uma legislação do trabalho inspirada nos mais amplos preceitos de justiça social e nos princípios da ordem social cristã, para trabalhadores tanto urbanos como rurais.

Dentro de poucos dias o eleitorado conhecerá a lista dos partidos que responderam favoravelmente à consulta que Ihes foi endereçada.

Os que porventura não figurem nesse rol já estão, automaticamente, apontados à desaprovação de todo brasileiro que deseje ver respeitadas as tradições pátrias, no texto da Constituição e das mais leis fundamentais a serem promulgadas.

Compete, porém, ao eleitor, escolher conscienciosamente o partido de sua preferência, dentre os indicados pela LEC. Esta indicação, conquanto seja um 
fator fundamental e preliminar, não dispensa, como é natural, o critério seletivo do voto.

Incumbe a cada um verificar se as atividades políticas, a atuação social, a honorabilidade, as virtudes pessoais, enfim, dos dirigentes das várias agremiações, constituem penhor de fidelidade aos ideais cristãos, por que se bate a LIGA. Também se torna imprescindível o cuidadoso exame dos diferentes programas partidários das soluções que apresentam para os magnos problemas nacionais das suas maiores ou menores afinidades com os objetivos da LEC.

Dentro desse vasto campo de apreciação individual é que o eleitor deverá, livre e escrupulosamente eleger o seu partido político. A LIGA não lhe força a consciência. Facilita-Ihe, apenas o exercício do dever cristão, apontando-lhe as linhas divisórias, traçadas pelos próprios partidos, ao aceitarem, ou rejeitarem as reivindicações mínimas e essenciais do eleitorado católico.

Não terminam aí, entretanto, os cuidados da LEC. Ela enviará ainda, a todos os candidatos dos partidos constantes de sua lista de aprovação, consulta idêntica à que dirigiu a essas entidades, a fim de que cada um possa individualmente tomar conhecimento do assunto e assumir clara responsabilidade pessoal. Os nomes dos candidatos que por sua vez tenham respondido afirmativamente ao questionário católico, serão de igual forma publicados. A omissão de alguém também aqui significa o repúdio da LEC à respectiva candidatura.

O eleitorado católico jamais deverá sufragar qualquer legenda que tenha como cabeça de chapa o nome do candidato que não conste da lista de aprovação acima referida.

Consequentemente, devem os eleitores votar nominalmente apenas naqueles que figurem entre os aprovados pela LIGA.

As mesmas observações relativas ao critério de seleção partidária tornamse oportunas no tocante à escolha individual. $O$ católico deve atender às qualidades pessoais do candidato, às suas convicções, ao seu caráter, à sua conduta pública e particular, para, afinal, votar nos que maiores garantias ofereçam.

Quando solicitadas, a LEC dará, pelos seus órgãos competentes, a todos os eleitores filiados ou não a partidos políticos a necessária orientação individual, 
de acordo com os princípios já explanados, a fim de que possam, conscientemente, escolher a cédula para a votação.

"Nenhum brasileiro, desde que preze as tradições do nosso povo, aceitará, portanto, cédula em que figure, como cabeça de chapa, qualquer nome não aprovado pela Liga Eleitoral Católica. É assim que na paz se defenderá o Brasil."70

Rejeição de todo monopólio educativo. Liberdade para o ensino religioso facultativo nos estabelecimentos oficiais de ensino (Quarta reivindicação constante do decálogo da LEC)

O monopólio da educação pelo governo atenta contra os fins do Estado, o direito da família, a eficácia da educação e o direito à vida religiosa.

Atenta contra os fins do Estado, porque o monopólio educativo é uma das formas mais terríveis de ditadura e totalitarismo. Não contentes de terem um poderio político ilimitado, querem os Estados totalitários, possuir o partido único, a imprensa única, a opinião única, a Escola Única e assim, impor uma mentalidade única, quase sempre favorável aos desígnios opressores e imperialistas do governo.

O monopólio educativo ofende também o direito natural da família à educação, porque não lhe permite mais orientar, formar e escolher a educação de seus filhos. A educação será feita, dirigida e determinada pelo governo.

O monopólio educativo é a negação mesma da educação. Educação e desenvolvimento interno espontâneo e livre das capacidades do indivíduo, e a escola única, principalmente nos regimes totalitários contemporâneos é imposição violenta.

Vindo sempre acompanhado da proibição do ensino religioso como se deu na França laicista, no século passado, na Alemanha nazista de ontem e na Rússia stalinista de hoje, o monopólio educativo ofende também o direito do homem à vida religiosa. Tirar a base religiosa da educação é destruí-la, porque educação não é simples transmissão de conhecimentos, mas, principalmente formação moral da personalidade. $E$ a formação moral supõe necessariamente

\footnotetext{
${ }^{70}$ O Estado de S. Paulo. 18.11.1945.
} 
uma base religiosa. Por essa razão, uma escola sem religião poderá transmitir conhecimentos ou fortalecer os músculos, nunca educar.

Por isso, a LEC quer a negação de todo o monopólio educativo e a liberdade de ensino religioso facultativo nos estabelecimentos de ensino. ${ }^{71}$

Novamente recomendando voto nos candidatos apoiados pela Liga Eleitoral Católica, na edição de 29 de novembro de 1945, há uma publicação mostrando os nomes dos candidatos nas eleições daquele ano aprovados pela Liga, ou seja, que se manifestaram favoráveis às normas ditadas pelos católicos. Estavam na lista os candidatos à presidência Eurico Gaspar Dutra e Eduardo Gomes, cinco candidatos a senador, pelo Partido Trabalhista Brasileiro (PTB), Partido Social Democrático (PSD) e União Democrática Nacional (UDN). Para Deputado, tiveram o "carimbo" da LEC 9 deputados do Partido Agrário Nacional (PAN), 23 do Partido Democrata Cristão, 23 do Partido Popular Sindicalista, 37 do Partido Social Democrático (PSD), 12 do PTB e 30 da UDN, incluindo D. Carolina Ribeiro, Diretora da Escola Caetano de Campos. ${ }^{72}$

Em 23 de novembro de 1945, uma manchete em letras garrafais diz "A introdução do Ensino Religioso nas escolas, conquista dos tempos, deverá ser mantida". A página inteira era sobre o programa do Partido Social Democrático e do seu candidato, o general Eurico Gaspar Dutra. O subtítulo mostrava: "a educação será um empreendimento do povo para o povo". O então candidato à presidência da República, de acordo com o jornal, não considerou a educação como uma superestrutura artificial à vida da Nação, mas antes a relacionou com a organização política, a realidade econômica, a estrutura religiosa e moral e com a vida do povo. Ao estabelecer essa conexão, "não foi o General Gaspar Dutra ao extremo, que seria considerar monopólio do Estado a ação educativa." Dutra afirmou que o Estado também não podia se mostrar indiferente ou pouco interessado na educação popular. O Estado poderia desenvolver um plano educacional de grande envergadura e proporcionar estímulo e amparo às forças educacionais da família, às iniciativas particulares, instituições, ordens religiosas e grupos profissionais, mantendo o Estado em relação a estes uma atuação coordenadora e vigilante. Combateu, ainda a educação dos regimes totalitários, a

\footnotetext{
${ }^{71}$ O Estado de S. Paulo. 18.11.1945.

${ }^{72}$ O Estado de S. Paulo. 29.11.1945.
} 
qual se destinava a fins políticos, não de livre realização da pessoa humana. "A educação, assim, deverá ser um empreendimento do povo e para o povo, uma expressão da própria democracia e um processo dentro do qual se revitalizarão os anseios democráticos da gente brasileira."73

Na mesma página, havia a orientação para o "Voto dos Católicos": "As mais recentes atitudes dos moços que em $\mathrm{S}$. Paulo se apegaram à figura do Brigadeiro Eduardo Gomes, para com mais chance tentar as suas aventuras políticas, devem ter acabado de desiludir de uma vez por todas os católicos paulistas. Há meses vinham os senhores da UDN fazendo planos conservadores, de absoluta conformidade com as doutrinas cristãs. E nelas procuravam apoiar até reformas sociais, tendo sempre como bandeira o apregoado espírito católico deles e do seu chefe. Tudo pura blague, mero estratagema para embair a boa fé da legião dos católicos e talvez da legião de senhoras católicas, em que tem feito repousar quase todas as suas esperanças nas eleições. Com efeito, o que vemos agora? Depois de muito despistar, depois de muita propaganda, tudo se revela nitidamente como simples caça ao voto: a UDN se casa com a assim chamada 'esquerda democrática'. Que é, afinal, essa 'Esquerda'? Comunismo do legítimo, tão legítimo quanto o outro, o do Sr. Fiúza. Não adianta quererem eles estabelecer diferenças entre trotskismo e leninismo ou stalinismo, linhas justas ou outras. Tudo isso é puro engodo, maneiras de se apresentar para burlar o repúdio que instintivamente despertam de parte das pacíficas e democráticas mães de famílias as denominações de comunista e bolchevistas, inimigos da família, da propriedade, são os adeptos da esquerda democrática. Ou isso, ou nada mais. Não há meio termo. Não há linha aí que, justa ou sinuosa não conduza à abolição dos princípios que tradicionalmente a família brasileira mantém e pelos quais está disposta a lutar com afinco. Pois é vinho dessa pipa, vermelhíssimo, da pura vinha soviética, que produziu a chapa de deputados da UDN: lá estão dois lídimos representantes dos sovietes com a máscara de 'esquerdistas'.

Bem por isso é que nos meios católicos já se começou a abrir os olhos, fazendo-se toda sorte de restrições à chapa de deputados da UDN. Ou somos democráticos, socialistas, socialistas democratas, ou comunistas: ser democrático e comunista e católico ao mesmo tempo, não é possível. Tomem bem nota disso

\footnotetext{
${ }^{73}$ O Estado de S. Paulo. 23.11.1945.
} 
os católicos, as mães de família, os moços, que tanto se vêm distinguindo na campanha eleitoral e meditem antes de votar, seja para deputado, seja para quem chefia a facção desses deputados." ${ }^{74}$

A Liga Eleitoral Católica e os partidos políticos: "Fiel à sua missão de orientar o eleitorado e polarizar os trabalhos em prol das reivindicações cristãs do povo, a LEC, à semelhança do que já fez nas anteriores eleições, iniciou as consultas e entendimentos com os diversos partidos políticos, no sentido de obter acolhida, nas futuras leis fundamentais do país, dos princípios consubstanciados no Decálogo, já amplamente divulgado.

Após o escoamento do prazo para registro definitivo das agremiações partidárias, serão indicadas ao eleitorado as que se propõem batalhar por aquele objetivo. Também, em ocasião oportuna, a LEC apontará nominalmente os candidatos que responderem de modo afirmativo à sua consulta e destarte, se comprometerem a defender seu programa de reivindicações mínimas.

Nesta segunda fase de atividades, está a LEC empenhada em intensa campanha de adesões, que se endereça, precipuamente, aos eleitores ex-ofício, ou alistados por outras entidades, partidárias ou extra-partidárias.

Como bem ressaltou, entretanto, o Sr. Arcebispo Metropolitano, ao traçar os rumos de tal campanha e como claramente decorre dos próprios termos da ficha de adesão, a LEC não pretende construir um eleitorado próprio. Sua posição é nitidamente doutrinária. $O$ apoio dos eleitores aos princípios que ela reivindica não impede, dessa forma, a arregimentação partidária, pelo que não só podem, mas devem os aderentes da LEC conservar-se ou ingressar nos partidos políticos de sua preferência, desde, é claro, que dos respectivos programas não constem itens que explícita ou implicitamente neguem as reivindicações cristãs constantes do já mencionado Decálogo, ou apóiem doutrinas formalmente condenadas pela Igreja.

A participação ativa dos católicos nas atividades partidárias, em tais condições, longe de ser inconveniente é, pelo contrário, sumamente desejável.

A adesão aos princípios da LEC, portanto, em nada impede as legítimas preferências de partido, ficando ao eleitor plena liberdade de se filiar, simultaneamente, à Liga e ao organismo político que mais o satisfaça, dentro

\footnotetext{
${ }^{74}$ O Estado de S. Paulo. 23.11.1945.
} 
daquelas instituições que se impõem naturalmente às consciências realmente cristãs.

Decálogo: das reivindicações que a Liga Eleitoral Católica pugnará para que sejam respeitadas na nova Constituição Brasileira, e nas leis fundamentais a serem promulgadas

1) Promulgação da Constituição em nome de Deus e instituição do novo Estado Democrático, segundo os princípios evangélicos de liberdade e justiça.

2) Reconhecimento dos direitos e deveres fundamentais da pessoa humana

3) Defesa da família, fundada no casamento indissolúvel, com o reconhecimento dos efeitos civis ao casamento religioso e assistência às famílias numerosas.

4) Rejeição de todo monopólio educativo. Liberdade de ensino religioso facultativo nos estabelecimentos oficiais de ensino.

5) Legislação do trabalho inspirada nos mais amplos preceitos de justiça social e nos princípios da ordem social cristã, para os trabalhadores tanto urbanos como rurais.

6) Preservação de propriedade individual, limitada pelo bem comum como base da autonomia pessoal e familiar.

7) Pluralidade sindical, sem monopólio estatal nem restrições de ordem religiosa.

8) Pluralidade partidária, com exclusão de organizações antidemocráticas.

9) Regulamentação da assistência religiosa facultativa às classes armadas, bem como aos hospitais, prisões e instituições públicas e reconhecimento do serviço eclesiástico de assistência espiritual às forças armadas, como equivalente do serviço militar.

10) Combate a toda e qualquer legislação que entrave, expressa ou implicitamente, os princípios fundamentais do direito natural e da doutrina cristã. ${ }^{75}$

\footnotetext{
75 O Estado de S. Paulo. 26.10.1945.
} 
O programa do Partido Democrata Cristão foi publicado no Estado de $S$. Paulo e uma nota de esclarecimento apresentava as possíveis relações entre a Igreja Católica e o grupo político: "o PDC, no intuito de evitar qualquer equívoco e a fim de fazer calar definitivamente alegações prejudiciais à Igreja e ao Partido, feitas por pessoas de opinião apressada, vem declarar publicamente que não tem quaisquer ligações oficiais, oficiosas ou extra-oficiais com a Igreja. O Partido sabe que a Igreja está fora e acima dos partidos políticos e logicamente não espera dela nenhum tratamento privilegiado. O partido trabalha como é evidente no campo social e político e, portanto, não apela nem pode apelar para o credo religioso dos cidadãos na sua propaganda partidária. $O$ nome do partido não contém confissão religiosa e tão somente se refere à democracia-cristã que é a fórmula de organização social aconselhada pelas Encíclicas pontificiais documentos que constituem patrimônio coletivo da civilização cristã. O programa do partido, moldado no movimento democrata-cristão existente em vários países, visa estabelecer um perfeito acordo entre o espírito cristão e o espírito democrático através da implantação de um regime político realmente popular, realmente democrata e realmente cristão.

A Convenção Nacional do PDC delibera combater doutrinária e politicamente os sistemas econômicos, sociais e políticos, condenados pela Encíclicas Pontificiais e todos os totalitarismos da direita e da esquerda, e no momento presente, notadamente o comunismo, o maior inimigo da Igreja e da civilização cristã. Esse combate franco, aberto e decidido, sem transigência nem conivência com a doutrina comunista, abrangerá tanto o campo negativo como o positivo, através de amplas reformas sociais.

A publicação do jornal declara que o Partido Democrata Cristão aceitou não apenas os quatro pontos mínimos da Liga Eleitoral Católica, mas todo o seu Decálogo e até mesmo todo o seu programa. Dentre os pontos de seu programa está incluir o ensino religioso dentro do horário escolar, respeitando as convicções de cada um. ${ }^{76}$

\footnotetext{
${ }^{76}$ O Estado de S. Paulo. 20.11.1945
} 
Capítulo 3

A organização do Ensino Religioso 
Desde os anos 1920, houve uma aproximação entre Igreja Católica e o governo central brasileiro, sendo que os católicos buscavam mais espaço, seguindo a orientação ultramontana da Santa Sé. Alguns autores estudaram profundamente a questão, mostrando certo autoritarismo da Igreja, conservadorismo, e tirando espaço de religiosos mais progressistas. Outros estudaram a pressão católica no ensino público e privado, já que era um precioso campo de propagação de ideias. A orientação romana fez com que várias iniciativas e organizações surgissem, tais como a criação do Centro Dom Vital, da revista $A$ Ordem, da Liga Eleitoral Católica, entre outras. O trabalho de Carlos Roberto Jamil Cury é um dos que mais se aproxima da relação entre Igreja Católica e educação. No entanto, sua análise restringe-se às discussões e debates para a inserção das questões religiosas na Constituição de 1934. O clássico Tempos de Capanema apresenta as relações entre o ministro da educação e a Igreja, nas quais é possível perceber uma grande força das autoridades católicas na política, através de correspondências diretas ao ministro, como também foi grande a pressão pela manutenção do ensino privado, área de maior influência dos católicos, e o afastamento de personalidades que tinham o objetivo de expandir a educação pública, gratuita e laica e foram taxados de comunistas, como é o caso de Anísio Teixeira. ${ }^{77}$

A intersecção entre os campos religioso e político foi extremamente necessária para os objetivos expansionistas da Igreja Católica. Todas as pressões para a aprovação do artigo 153 da Constituição de 1934 e da Lei Estadual 6766, que tornavam o ensino religioso presente nas escolas públicas, foram fundamentais na manutenção do projeto católico.

Em 1929, foi impresso o Estatuto da Liga do Professorado Católico de São Paulo, com assinatura, na contracapa, do Cardeal Arcebispo Metropolitano de São Paulo Dom Duarte Leopoldo e Silva. O documento trazia como um dos fins

\footnotetext{
${ }^{77}$ Ver: BEOZZO, José Oscar. A Igreja entre a Revolução de 1930, o Estado Novo e a Redemocratização. In: FAUSTO, Boris. História da Civilização Brasileira: O Brasil Republicano: Economia e cultura - 1930 1964. Tomo II, v. 4º. São Paulo: Difel, 1997. CURY, Carlos Roberto Jamil. Ideologia e Educação Brasileira: católicos e liberais. São Paulo: Cortez, 1984. DIAS, Romualdo. Imagens de ordem: a doutrina católica sobre autoridade no Brasil (1922-1933). São Paulo: Editora da UNESP, 1996. SCHWARTZMAN, Simon; BONEMY, Helena Maria Bousquet; COSTA, Vanda Maria Ribeiro. Tempos de Capanema. Rio de Janeiro: Paz e Terra; São Paulo: EDUSP, 1984.
} 
principais o aperfeiçoamento intelectual, moral e religioso de seus membros, além de promover a união de classe, sem interesses partidários, proteger seus membros em público ou em particular, garantindo-lhes o respeito e a consideração a que tinham direito como formadores do caráter nacional, amparar professores pobres, protegê-los nas enfermidades, dando-lhes assistência médica, moral e religiosa e proteger materialmente os aspirantes ao magistério, dando-Ihes, igualmente, assistência intelectual, moral e religiosa. ${ }^{78}$

Na sede da Liga, seriam proporcionadas aos professores aulas gratuitas de Religião, de idiomas e datilografia e uma biblioteca científica e religiosa com exclusão de quaisquer obras contra a fé e a moral ou pretensamente literárias.

Podiam ser sócios da Liga, as senhoras e moças católicas com atuação no magistério público ou particular, alunas das escolas normais ou professores de ambos os sexos que não contrariassem os fins da organização. Havia cinco categorias de sócios: 1ํ Sócias ativas ou professoras em exercício na capital paulista que contribuíam com a mensalidade de cinco mil réis; $2^{\circ}$ Sócias efetivas, ou professoras em exercício no interior do Estado, que contribuíam também com cinco mil réis. Estas tinham uma zeladora residente na capital paulista, que deveria manter-se em constante comunicação com a Diretoria; 4ํ Sócios contribuintes ou professores de ambos os sexos que se interessassem pelos fins da Liga, contribuindo com a mesma mensalidade. 4ํㅗ Sócias iniciadas ou aspirantes que eram, no caso, as alunas das Escolas Normais, que contribuíam com $12 \$ 000$ anuais; $5^{\circ}$ Sócios beneméritos ou honorários que contribuíssem com $200 \$ 000$ ou $500 \$ 000$ anuais.

Para ser admitido como sócio, era preciso que o professor ou professora fosse apresentado por uma zeladora ou um membro da Diretoria, não podia pertencer a nenhuma associação secreta ou condenada pela Igreja, provar que era casado segundo os mandamentos da Igreja e que cumpriu as formalidades civis para a constituição da família.

\footnotetext{
${ }^{78}$ ARQUIVO DA CÚRIA METROPOLITANA. Estatuto da Liga do Professorado Paulista. Pasta CBA 0602-18: Agremiação de Professores, 1929.
} 
A Direção da Liga sempre seria entregue a um eclesiástico, representante do Sr. Arcebispo Metropolitano, a quem a Liga reconhecia por sua autoridade suprema e diretor nato. No Artigo $\mathrm{V}$ do Estatuto, afirma-se que a Liga do Professorado inspira-se na direção que imprimirem as autoridades eclesiásticas à Ação Católica, protestando inteira adesão aos ensinamentos da Igreja e seus representantes.

No artigo 39 do Estatuto, estão dispostas as proibições sobre a venda, hipoteca e alienação de qualquer bem do patrimônio da Liga sem autorização expressa de uma autoridade eclesiástica, pois os bens que constituíam o patrimônio da associação eram bens eclesiásticos e a Liga, apenas "fiel e zelosa administradora".

Encerrando o documento, $\circ \S 6^{\circ}$ do artigo 40 expressava que todos os membros da Liga se comprometeriam, perante Deus e a sociedade, a contribuírem para a propagação do culto católico e elevação moral e social da classe.

Em um panfleto da Organização chamada Legião de São Paulo, de 25 de janeiro de 1935, dirigido ao professorado católico, há, primeiramente um recado às catequistas, dizendo que a grande preocupação delas deveria ser habituar as crianças a praticarem o que se aprende no Catecismo, isto é, a viverem cristãmente. Era preciso habituá-las a fazerem oração pela manhã e à noite, a ouvirem missa de preceito, a assistirem as aulas de Catecismo, a frequentarem os sacramentos e outros exercícios da vida cristã, como a assistência piedosa ao belo culto de Nossa Senhora, no mês de maio. Os membros da Legião deveriam ter o maior cuidado e zelo, esforçando-se sempre e em toda parte, por preservar as crianças do mal, aconselhando-Ihes grande devoção e firme confiança no anjo da guarda. [...] Cumpria preparar antecipadamente a lição que se deveria dar, pensando sobre o que e como iriam falar. $\mathrm{O}$ fim era fazerem das crianças ótimos cristãos, não só Ihes ensinando o Catecismo, mas também Ihes inculcando modos convenientes, sempre procurando levantar e enobrecer seus sentimentos. Uma boa catequista era aquela que estudava o meio e o modo de ensino que mais se adaptasse à inteligência da criança e se instruísse na religião para melhor ensiná-la e praticá-la. 
Dirigindo-se aos professores paulistas, o documento proclama que enfim, naquela data, iniciar-se-ia o ensino religioso nas escolas paulistas. A Legião de São Paulo, que se descrevia como vanguardeira da organização catequista no Estado, afirmava sentir bem o peso das responsabilidades que Ihe cabiam, porém tudo esperava e confiava na cooperação do professorado paulista. Todos sentiam que Deus apelava aos professores, que sempre saberiam servir e engrandecer a Pátria, bem como completar a sua missão; nem se compreenderia que Professores Católicos se desinteressariam pelo ensino da sua religião, e que eles, com o mais desvelado carinho, cultivariam a inteligência das crianças, permitindo que outros Ihes roubem a dignidade e a glória de cultivar-Ihes a alma. Não seria possível: civismo e religião se irmanavam no coração do Professorado Católico de São Paulo e "bendito será o mestre que, ao transpor os umbrais da eternidade, possa, tranquilo, dizer: servi à minha Pátria e ao meu Deus."

O panfleto apelava para que os professores se integrassem cordialmente na Legião de São Paulo correspondendo a sua alta finalidade, e assim, eles se mostrariam grandes como a sua terra, nobres como sua gente, heróicos como seus antepassados, piedosos e bons como Anchieta, o seu primeiro mestre. E, como o Apóstolo que batizou a terra de São Paulo, saberiam ouvir e cumprir o grande mandato: "Ide e ensinai". Concluindo: "O Professorado Católico de São Paulo ensinará às crianças a ciência verdadeira, e fá-lo-á bem, porque é católico e porque é paulista por mercê de Deus. ${ }^{79}$

Um folheto da Legião de São Paulo traçava um Plano da Organização do ensino Religioso em São Paulo, formando uma Comissão Diretora para a organização do ensino religioso nas escolas de São Paulo. Esta seria composta por assistentes eclesiásticos da Legião de São Paulo e da Liga do Professorado Católico e de elementos das duas associações. Os trabalhos se desenvolveriam em duas seções: Formação de Catequistas, a cargo dos sacerdotes e Ensino Religioso escolar, a cargo de elementos leigos. A primeira deveria manter um Curso Superior de Formação e Orientação de professores leigos de catequistas, que se incumbiriam de preparar e orientar o professorado: zeladores e

\footnotetext{
${ }^{79}$ ARQUIVO DA CÚRIA METROPOLITANA. Legião de São Paulo. Pasta CBA 06-02-18: Agremiação de Professores, 25/01/1935.
} 
catequistas. A segunda seção abrangeria três departamentos: Ensino Secundário e Profissional, Ensino Público Primário e Ensino Particular. ${ }^{80}$

O Departamento de Ensino Superior se prenderia ao Curso Superior de Formação e Orientação, do qual receberia professores de religião para escolas normais, profissionais, ginasiais e universidades. O Departamento de escolas Públicas Primárias dividiria o trabalho por setores com seus chefes que deviam controlar o trabalho religioso de três ou mais grupos escolares e escolas isoladas, sempre em pleno entendimento como Revmo. Vigário da paróquia, coordenando o trabalho das zeladoras.

As zeladoras seriam três em cada grupo escolar e a elas competia zelar pela fiel execução do decreto governamental, que regulamentou o art. 153 da Constituição Federal, sobre o ensino religioso, verificando se as aulas são dadas nos dias e horas determinadas e com duração prevista, de tudo informando ao chefe do setor que assim estaria a par de todas as ocorrências bem como do desenvolvimento das aulas dadas pelas catequistas. ${ }^{81}$

Em 1935, pelo decreto da Sagrada Congregação do Concílio "De cathechistica institutione impensius curanda et proveenda" foi instituída a Diretoria Arquidiocesana do Ensino Religioso de São Paulo. O órgão era de verdadeira fiscalização, fazia visita a escolas e realizava inquéritos. Em 9 de agosto de 1935, foi impresso o documento que estipulava as regras da organização. Na primeira página, apareciam as palavras e a assinatura do Arcebispo D. Duarte Leopoldo e Silva. No artigo $2^{\circ}$, a Diretoria se intitulava "um órgão técnico e executivo que tem a seu cargo coordenar, orientar, administrar e fiscalizar todo o ensino religioso dentro dos limites da Arquidiocese". No artigo seguinte, a Diretoria se propunha organizar todos os serviços administrativos e técnicos de coordenação, orientação, administração e inspeção necessários para garantir a rigorosa ortodoxia, o bom funcionamento e a máxima eficiência do ensino religioso em

\footnotetext{
${ }^{80}$ ARQUIVO DA CÚRIA METROPOLITANA. Plano de Organização da Legião de São Paulo. Pasta CBA 06-02-33: Educação Religiosa Católica, s/d.

${ }^{81}$ ARQUIVO DA CÚRIA METROPOLITANA. Plano de Organização da Legião de São Paulo. Pasta CBA 06-02-33: Educação Religiosa Católica, s/d.
} 
toda a Arquidiocese. A organização era integrada pelo Conselho Arquidiocesano do Ensino Religioso, Secretaria Arquidiocesana, Tesouraria e Departamento Administrativo, Departamento Técnico de Formação de Catequistas e Inspetoria Arquidiocesana.

O Conselho Arquidiocesano era formado por três representantes do clero paroquial, três do clero regular, um representante da Confederação Católica Brasileira de Educação, um da Legião de São Paulo, um da Liga do Professorado Católico, um do professorado público, um do particular e um da Juventude Católica. Aos representantes do Conselho competiam, entre outras coisas: entender-se com as autoridades do Ensino Público no sentido de serem respeitados e executados à risca os dispositivos legais sobre o ensino religioso nas escolas públicas e oficiais, fixar as diretrizes do ensino religioso na Arquidiocese, promover anualmente uma Semana do Catecismo, na qual deverão tomar parte e prestar o seu concurso, todas as escolas e colégios católicos da Arquidiocese. 82

O Conselho Arquidiocesano do Ensino Religioso, pelo estatuto deveria designar o pessoal necessário para o bom funcionamento da Tesouraria, assim como estava estabelecido propor ao Sr. Arcebispo a data e o número das coletas dominicais que julgar necessárias para conseguir a receita calculada, organizando o quanto antes a Associação Beneficente da Doutrina Cristã.

O Departamento Administrativo do Ensino Religioso era o órgão executivo que tinha a seu cargo: organizar o Ensino Religioso em todas as escolas públicas e particulares, fazer anualmente o alistamento de professores e catequistas da Arquidiocese aptos para ministrar $o$ ensino religioso e distribuí-los convenientemente entre as escolas, promover e organizar as festas de $1^{\text {a }}$ Comunhão, as comunhões pascoais e coletivas da infância escolar e demais festas de caráter religioso-escolar; fazer requisições ao almoxarifado e à caixa da Tesouraria do material e dinheiro necessários para o bom funcionamento do ensino religioso em todos os setores e distribuí-los devidamente.

\footnotetext{
${ }^{82}$ Sobre a Liga do Professorado Católico, ver PINHEIRO, Ana Regina. Instrução do povo sob a proteção do catolicismo - militância docente e a expansão da escolarização em São Paulo. Revista Brasileira de História da Educação, Maringá-PR, v. 15, n. 2 (38), p. 193-219, maio/ago. 2015
} 
Foram feitas duas divisões no Departamento Administrativo do Ensino Religioso: uma seção de catecismos paroquiais e outra de catecismos escolares, cuja diretoria deveria envolver representantes da Legião de São Paulo e da Liga do Professorado Católico, exercendo a sua atuação através de comissões de Ensino Particular, de Ensino Publico Primário e de Ensino Profissional e Normal. Cada uma das comissões deveria nomear em cada uma das escolas de seu setor as Delegadas responsáveis pelo funcionamento do ensino religioso nos seus respectivos turnos e pela rigorosa execução das diretrizes emanadas do Conselho Arquidiocesano do Ensino Religioso.

O artigo 20 do estatuto estipulava a organização e manutenção de uma Escola de Formação Catequética, com sede na Cúria Metropolitana e filiais nos distritos de maior conveniência para o professorado e em todos os colégios secundários femininos e masculinos da Arquidiocese. O curso teria duração de um ano escolar e constaria de: um curso completo de Doutrina Cristã nas bases do catecismo de Trento; curso completo de metodologia do ensino religioso para os graus primário e secundário; um curso de História da Igreja e um curso de apologética.

O órgão mais incisivo da Diretoria Arquidiocesana era a Inspetoria do Ensino Religioso. Era um serviço de vigilância contínua nas escolas públicas. Suas atribuições estabelecidas eram: velar, na abertura de cada ano letivo, pela regularidade do serviço de matrículas para o ensino religioso nas escolas públicas; preparar um corpo técnico de inspetores do ensino religioso, de preferência entre o clero regular e secular; promover, periodicamente, inquéritos entre os professores e catequistas sobre as deficiências e méritos dos métodos empregados; organizar, anualmente, uma exposição de trabalhos e gráficos catequéticos. 
Figura 1 -

Organograma da Diretoria Arquidiocesana do Ensino Religioso

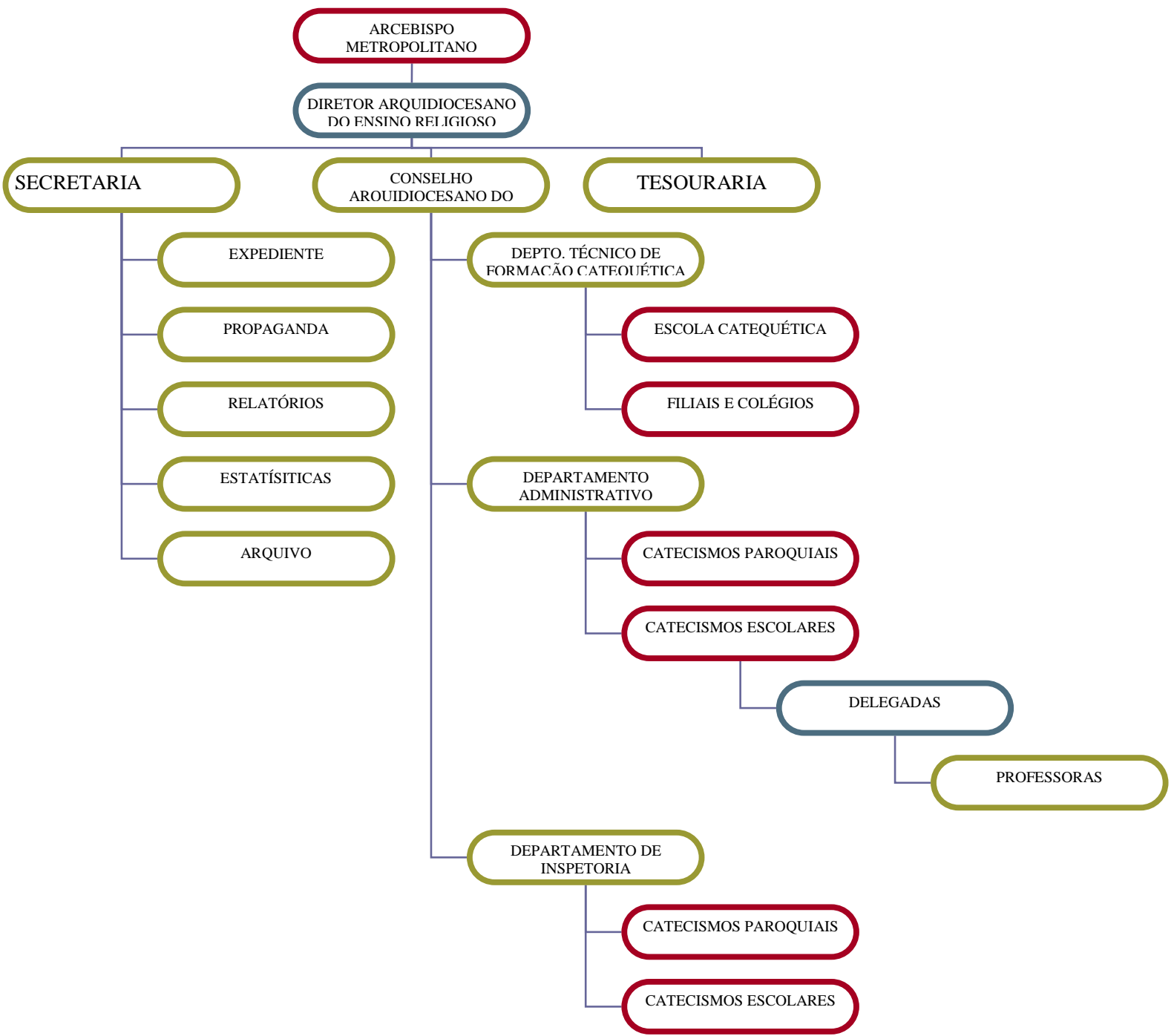

Fonte: Estatuto da Diretoria Arquidiocesana do Ensino Religioso

O livro que apresenta toda a organização da Diretoria Arquidiocesana do Ensino Religioso publicou também o decreto que incorporava o Ensino Religioso ao regime escolar dos estabelecimentos oficiais do Estado de São Paulo, que entrou em vigor no dia 11 de outubro de 1934. O ensino religioso ficava incorporado ao regime escolar dos estabelecimentos oficiais do ensino primário, secundário, profissional e normal. 
O pedido de matrícula, pelo artigo $2^{\circ}$, dos alunos que tivessem de receber ensino religioso nestes estabelecimentos devia vir acompanhado de documento assinado pelo pai ou responsável, declarando qual a confissão religiosa e cujos princípios desejava serem ministrados a seu filho ou tutelado.

O ensino religioso seria ministrado uma vez por semana, na segunda hora de aula, cabendo aos ministros do respectivo culto a organização dos programas e a escolha de livros.

Os professores poderiam lecionar religião desde que fossem designados pela Igreja, no caso. Porém não era permitido a eles impugnar ensinamentos religiosos ou ofender os direitos dos alunos, ou ainda provocar debates entre os alunos de confissões diferentes. Era expressamente proibido aos professores do Estado fazer propaganda de qualquer credo religioso no sentido de influir que seus alunos aceitem o ensino da doutrina ou do culto que professam. Também não seria permitida a existência de símbolos de qualquer culto, bem como a distribuição de folhetos ou impressos de propaganda religiosa.

Do mesmo modo, estava publicado no livro uma determinação da Diretoria Geral do Ensino às autoridades escolares sobre a incorporação do ensino religioso ao regime escolar. $\mathrm{O}$ artigo 3 o estipulava que no livro de matrícula e no de chamada diária deveria ser aberta uma coluna em que se faria constar a confissão religiosa a que os alunos pertenciam de acordo com a declaração do documento preenchido pelos pais. No artigo $7^{\circ}$ estava decidido que não seriam permitidas senão às autoridades do ensino e às do competente culto religioso a inspeção e vigilância do ensino religioso.

No mesmo estatuto da Diretoria Arquidiocesana do Ensino Religioso estava publicado um Decreto sobre a disciplina catequética, seu cuidado e incremento. Nele, a Igreja expressava a necessidade do catecismo: "Precisamente, na instrução catequética, se contém a ciência, pela qual se propõe e explana, de acordo com a capacidade e condição dos ouvintes, uma súmula de 
conhecimentos sobre Deus e Jesus Cristo, sua doutrina e moral." ${ }^{33}$ De acordo com o documento, a educação religiosa era de grande utilidade para todos, mas especialmente para as crianças e os moços, que seriam a esperança do futuro. Era urgente a instrução catequística naquele momento, devido ao desejo universalizado do saber e a geral possibilidade de aprender por melhores métodos que facilitava e antecipava a educação profana das crianças e dos jovens: "fora absurdo, no meio de tão grande aparato de conhecimentos e ardor de aprendizado, desleixar-se ou olvidar-se a ciência de Deus e das cousas mais importantes como as que se contém na religião." ${ }^{44}$

A participação do Estado na educação religiosa das crianças e adolescentes devia ser patente. Para as autoridades eclesiásticas, muito importava ao Estado e à Religião, que os cidadãos, ao lado de conhecimentos meramente humanos e dos preceitos da educação civil, adquirissem sentimentos cristãos.

O estatuto relata as dificuldades e os empecilhos à força e eficácia da Doutrina Cristã. Em primeiro lugar, a incúria dos pais, dos quais muitos, ignorantes das coisas divinas, menosprezavam ou simplesmente descuravam a instrução religiosa dos filhos. "O que é sumamente lastimável, pois se os pais são negligentes ou adversos, quase nenhuma esperança há de que os filhos venham um dia a se instruírem religiosamente."

Era uma falta que se agravava onde, como acontecia em certas nações, mercê da emulação das facções, o direito da Igreja na instrução cristã das crianças periclitava ou era negado totalmente. "Realmente detidos pela negligência ou leviandade, ou necessitados pelas circunstâncias, os pais não resistem às leis iníquas, nem empregam qualquer esforço ou solicitude para que os filhos sejam catequizados." 85 Outro fator apontado para a má formação religiosa eram os casamentos mistos. Conforme o relatório, nas regiões em que católicos e acatólicos viviam conjuntamente e não receavam unirem-se em matrimônio, acontecia, o mais das vezes que, da comunhão de vidas, resultava

${ }^{83}$ ARQUIVO DA CÚRIA METROPOLITANA. Diretoria Arquidiocesana do Ensino Religioso. Pasta CBA 06-02-23, 1935.

${ }^{84}$ Ibid.

${ }^{85}$ Ibid. 
nos pais e nos filhos um menosprezo das coisas divinas e um desfalecimento da fé.

Acrescentava ainda a indolência das crianças e dos jovens, que se preocupavam com outras coisas, preferiam os jogos e exercícios corpóreos, procuravam, nos dias de festa, espetáculos profanos, nos quais se relaxariam os costumes. "Eles, evidentemente, desleixam a freqüência ao catecismo paroquial e assim, desde a primeira infância começa, para agravar-se com o correr dos anos, aquele esquecimento e menosprezo das cousas divinas, por nós tão deplorado." Este esquecimento e incúria trariam ainda maior detrimento à fé, segundo a Arquidiocese, porque estavam surgindo no mundo lobos rapaces que não poupavam o rebanho. Insinuaram-se falsos doutores, servos do ateísmo ou do neo-paganismo, indulgentes para os desvarios humanos, que, com palavras e atos, esforçavam-se veladamente por destruir nos fiéis a fé em Deus, em Jesus Cristo e no ministério da Igreja. A estes se assemelham todos os que, na ativa propaganda de um protestantismo funesto que reveste aparência de fé e piedade cristãs, de modo incrível, enganam facilmente aos ignorantes da doutrina cristã e mesmo a fiéis simples e incautos.

Os Bispos eram conclamados, no texto, a acrescentarem cuidados ainda maiores e zelo cuidadoso aos esforços e diligências que anteriormente costumavam votar à catequese. Citando o Código de Direito Canônico, "ao Ordinário do lugar cabe providenciar na sua diocese sobre o que diz respeito à formação do povo na doutrina cristã" cada Bispo deveria examinar que coisa pudesse, em benefício da obra, prover o que desejasse e, se necessário fosse, lançar mão de penas eclesiásticas, conforme os cânones, contra os negligentes ou recusantes. Também deviam declarar os Bispos que no provimento das paróquias ou de outros benefícios, levar-se-ia muito em consideração o zelo e diligência empregados no ensino do catecismo, "assim manifestando a suma importância dessa obra".

Entre as obrigações dos Bispos, ditadas pelo decreto, estava a escolha de idôneos Sacerdotes Visitadores, que todos os anos inspecionassem as escolas de religião de sua diocese e informassem com segurança sobre o êxito da instrução religiosa nas mesmas, seu incremento ou deficiências. Citando o papa 
Bento XV, relatava: "muito poderá auxiliar a instrução do povo cristão elegerem-se visitadores que percorrendo a cidade e a diocese inquiram com sedulidade de todas as coisas, para que o Bispo, de tudo informado, determine prêmios ou penas, segundo o merecimento de cada um." $86 \mathrm{Na}$ arquidiocese de São Paulo, o inspetor do ensino religioso foi durante o período estudado o Padre João Pheeney de Camargo e Silva. Ele visitou escolas da rede pública e assinou diversos inquéritos a partir de 1940.

Para ensinar a catequese, na escola ou nas igrejas, dever-se-ia conseguir catequistas idôneos principalmente que estivessem inscritos nas Associações da Ação Católica. Se tudo fosse realizado como proposto pela Arquidiocese, conclui o documento, a Igreja poderia esperar para o futuro um povo cristão, seguramente munido de sã doutrina contra as insídias do erro um povo que "praticará gostosamente as boas obras, um povo que fruirá os efeitos salutares que os Romanos Pontífices não poucas vezes desejaram para a salvação das almas." Assina o decreto o Cardeal Serafini, prefeito.

Em 1934, houve a formatura da primeira turma de professores catequistas que receberam o Curso de Religião na Cúria Metropolitana. A Ata do encerramento das aulas dizia que as aulas foram dadas pelo Revmo. Padre Annibal Giavino, "que soube com carinho paternal e grande competência, plenamente satisfazer as altas afinidades deste Curso". Cento e vinte alunas, professoras de grupos da Capital paulista "colocaram-se à altura do professor e do motivo das aulas: obedientes, dóceis, esforçadas, vencendo fadigas naturais da profissão, perfeitamente compenetradas de seus deveres a cumprir." 87

O encerramento do curso contou com uma missa de Ação de Graças na Igreja de Santa Ifigênia e para entrega de diplomas, realizou-se um festival líteromusical, no qual foi paraninfo o Monsenhor Ernesto de Paula, "cujas palavras vibrantes de religioso entusiasmo deixaram nas almas um sentimento de pura

\footnotetext{
${ }^{86}$ ARQUIVO DA CÚRIA METROPOLITANA. Diretoria Arquidiocesana do Ensino Religioso. Pasta CBA 06-02-23, 1935.

${ }^{87}$ ARQUIVO DA CÚRIA METROPOLITANA. Ata do encerramento das aulas do curso de Religião na Cúria Metropolitana. 30.11.1934.
} 
felicidade e de imorredoura gratidão aos que, com tanto zelo, conduzem os destinos da Religião em nosso País."

Figura 2 - Formatura da Primeira Turma de Catequistas do Curso de Religião na Cúria Metropolitana

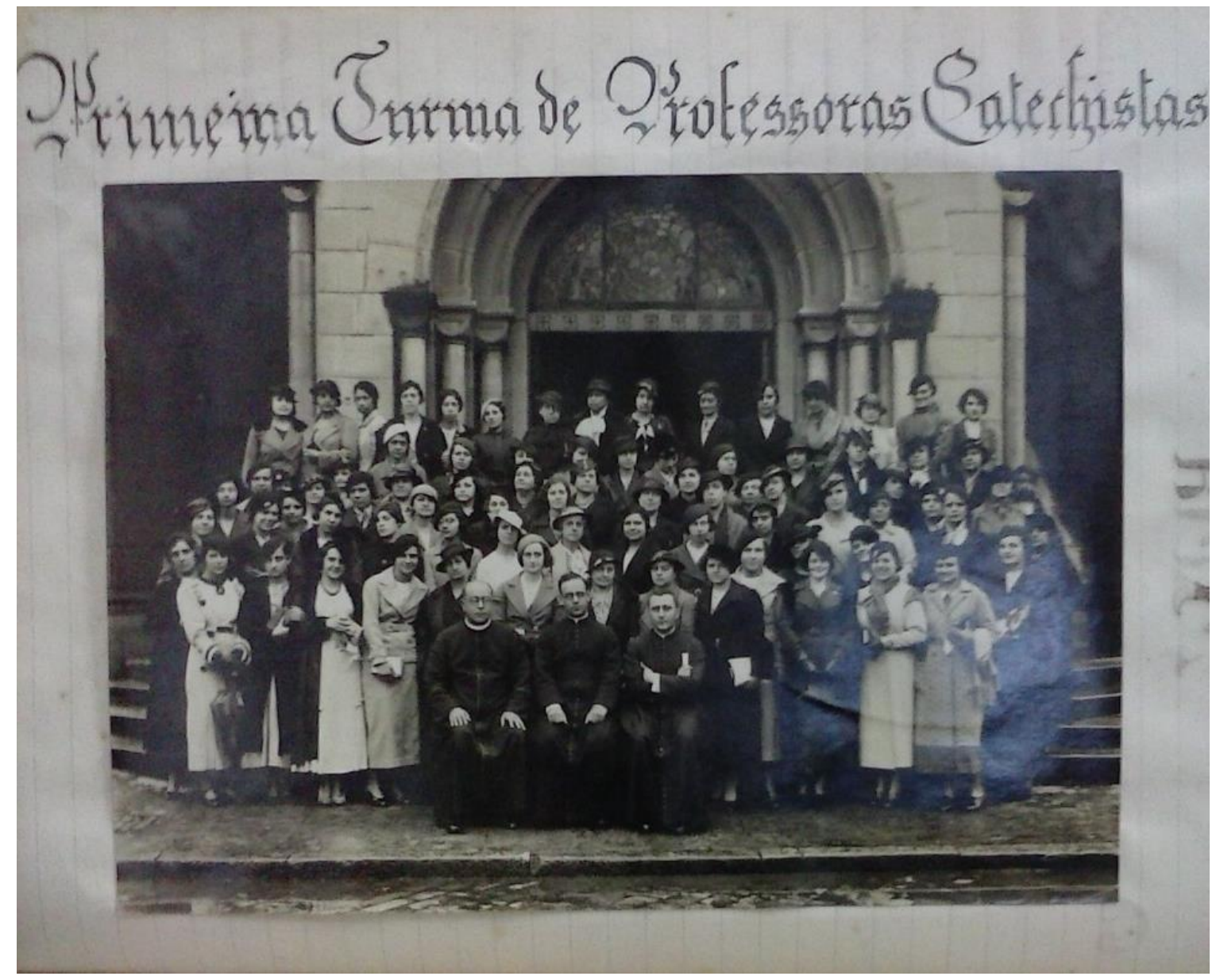

Fonte: Arquivo da Cúria Metropolitana

Diversas correspondências de professores ou diretores, Centro do Professorado Paulista ou Liga do Professorado Católico podem ser observadas no arquivo dos Arcebispos. Algumas contêm observações, a lápis ou à caneta, orientando a resposta que deveria ser dada às cartas. Comunicações de retiro de Professores durante a Páscoa, por parte da Liga do Professorado; agradecimentos por palavras proferidas aos professores católicos; convites para 
celebrações nas escolas eram comuns à mesa dos Arcebispos D. Duarte Leopoldo e D. José Gaspar. ${ }^{88}$

A Associação dos Antigos Alunos dos Padres Jesuítas escreveu ao Arcebispo D. Duarte Leopoldo dedicando integral obediência e completa solidariedade espiritual e cívica na defesa do ensino religioso nas escolas públicas como "fundamento essencial dos princípios morais que devem informar o coração e o caráter das novas gerações brasileiras." 89

O diretor do Grupo Escolar do Sacoman convidou o Arcebispo D. José Gaspar para comparecer a uma cerimônia de inauguração dos retratos de Getúlio Vargas, Ademar de Barros e Álvaro de Figueiredo Guião, então Secretário da Educação e Saúde Pública, que seriam expostos na escola para "consagrar aos grandes vultos de nossa Pátria uma capítulo de gratidão". A carta do Diretor do Grupo solicitava a presença do Arcebispo, pois sua presença, com o prestígio de seu acendrado patriotismo seria motivo de orgulho para o estabelecimento. Dom José Gaspar escreveu embaixo, a lápis, dando ordem para enviar um telegrama dizendo que não poderia comparecer. 90

Dona Carolina Ribeiro, Diretora da Escola Caetano de Campos, também fez convite ao Arcebispo Metropolitano. Era por ocasião da inauguração do Auditório da Instituição, no dia 26 de abril de 1941, comemorando, da mesma forma, o terceiro aniversário do "patriótico Governo o do Exmo. Sr. Dr. Ademar de Barros." 91

O principal livro didático utilizado nas escolas para as aulas de ensino religioso chamava-se: Exercícios Práticos de Catecismo do Padre C. Quinet. Era um pequeno livro, quase obrigatório na educação religiosa, pois os delegados da Diretoria Arquidiocesana e os Inspetores interrogavam se as escolas possuíam o

\footnotetext{
${ }^{88}$ ARQUIVO DA CÚRIA METROPOLITANA. Pasta CBA 06-02-18: Agremiações de Professores. Cartas da Presidente da Liga do Professorado Católico Ludovina Credídio Peixoto ao Arcebispo D. José Gaspar de Afonseca e Silva, 08.04.1941, 26.05.1941, 14.06.1981, 23.10.1941.

${ }^{89}$ ARQUIVO DA CÚRIA METROPOLITANA. Pasta CBA 06-02-18: Agremiações de Professores. Carta da Associação dos Antigos Alunos dos Padres Jesuítas ao Arcebispo Metrop. de São Paulo D. Duarte Leopoldo e Silva, 04.01.1932.

${ }^{90}$ Carta do Diretor do Grupo Escolar do Sacomã para o Arcebispo D. José Gaspar. 22.09.1939. Diretoria Arquidiocesana do Ensino Religioso. Pasta 06-02-23. A cerimônia aconteceria em 26.09.1939.

${ }^{91}$ Carta de D. Carolina Ribeiro para o Arcebispo D. José Gaspar. 23.04.1941. Diretoria Arquidiocesana do Ensino Religioso. Pasta 06-02-23.
} 
manual e quantos haviam adquirido. Na capa da obra, havia a informação de que o Padre C. Quinet era Inspetor Arquidiocesano do Ensino Religioso em Paris. O livro deveria ser para uso de todas as Dioceses e era redigido segundo os métodos pedagógicos de ensino. Possuía a aprovação de D. José Gaspar, D. Duarte Leopoldo e Silva e do Bispo de São Carlos, Dom Gastão Liberal Pinto.

No texto de aprovação da obra, o Arcebispo D. José Gaspar afirmou que a adoção dos Exercícios Práticos do Catecismo pelas Diretorias do Ensino Religioso das várias Dioceses da Província Eclesiástica de São Paulo, como texto oficial para as aulas de Religião nas escolas públicas veio dar solução a um problema que de há muito a estava reclamando. Tratava-se de um comentário fácil e sugestivo ao Catecismo oficial. Não o recomendassem, na sua primeira edição, tantos e tão venerados prelados, já por si mesmo se imporia à afeição das crianças e à estima dos professores. "Aqui deixo os meus ardentes votos: tenha este livro nas mãos cada uma das crianças dos nossos grupos e escolas, e com ele aprendam a estudar a Fé e a praticá-la seriamente, a fim de crescerem firmes e estáveis em Cristo Senhor Nosso. Não será muito desejar e exigir isto dos nossos pequeninos quem os ama ternamente, porque é pedir-lhes tudo o que pode fazê-los felizes nesta vida e na outra.

As nossas queridas e abnegadas professoras e catequistas, que sabem encontrar tempo e forças para o ensino religioso, provando assim quanto é generosa a sua fé, rogamos que divulguem o presente manual e dele se sirvam em suas aulas." 92

O Padre João Pheeney, Diretor Arquidiocesano do Ensino religioso fez a apresentação do livro escrevendo:

É com imensa satisfação que o Órgão Central Metropolitano do Ensino Religioso da Província eclesiástica de São Paulo apresenta às zelosíssimas catequistas de todo o Estado esta edição dos Exercícios Práticos de Catecismo da autoria do Revmo. Cônego Quinet.

\footnotetext{
92 ARQUIVO DA CÚRIA METROPOLITANA. Texto de aprovação do Arcebispo Metropolitano de São Paulo D. José Gaspar de Afonseca e Silva ao Livro Exercícios Práticos de Catecismo do Pe. Quinet. 29.05.1940. Pasta 06-02-23 - Diretoria Arquidiocesana do Ensino Religioso.
} 
A experiência de anos tem feito ressaltar claramente a necessidade absoluta de um texto na mão das crianças, para haver verdadeiro aproveitamento no ensino de catecismo.

É preciso fazer com que a criança não se limite a ouvir as preleções dadas em classe, ainda que muito substanciosas, mas recorde em casa e transcreva para seu caderno exercícios práticos. Indispensável se torna que viva a criança os ensinamentos aprendidos; só assim se obterá aproveitamento eficiente do ensino: enriquecendo a inteligência com os conhecimentos básicos da religião e simultaneamente orientando a formação moral da consciência e do coração.

A eficiência do ensino religioso por uma orientação segura, eis o que almejam os Revmos. Diretores Diocesanos desta Província, adotando como texto oficial de aula, no curso primário, estes Exercícios, que não dispensando o Catecismo Diocesano vem completá-lo com extraordinárias vantagens. ${ }^{93}$

Dom Duarte Leopoldo, no prefácio à primeira edição, redigiu seu imenso prazer em apresentar aos catequistas um bom guia para o ensino da doutrina cristã. O livro era adaptado aos novos métodos pedagógicos, sem prejuízo das linhas gerais impostas pela tradição. O guia não substituía, segundo o Arcebispo, os manuais diocesanos, mas os supunha e completava. Todavia, nenhum método dispensaria o zelo do catequista. Somente no calor da fé é que cresceria no coração da criança o gérmen da instrução religiosa. ${ }^{94}$

Dom Gastão Liberal Pinto assinalou que a obra do Padre Quinet, composta para ministrar às crianças as verdades da fé cristã e conforme um método sugerido pela experiência de um verdadeiro cura de almas, ora era divulgado em língua portuguesa, devido ao bom querer e tenacidade de uma alma zelosa da maior glória de Deus. Segundo o Bispo, a publicação vinha em ocasião oportuna, pois a nova lei básica que presidia os destinos da nacionalidade facultou o ensino

\footnotetext{
93 ARQUIVO DA CÚRIA METROPOLITANA. Texto de Apresentação do Padre João Pheeney ao Livro Exercícios Práticos de Catecismo do Pe. Quinet. 29.05.1940. Pasta 06-02-23 - Diretoria Arquidiocesana do Ensino Religioso.

${ }^{94}$ ARQUIVO DA CÚRIA METROPOLITANA. Texto de Apresentação do Arcebispo Metropolitano de São Paulo Dom Duarte Leopoldo ao livro Exercícios Práticos de Catecismo do Pe. Quinet. 11.11.1936. Pasta 0602-23 - Diretoria Arquidiocesana do Ensino Religioso.
} 
religioso nas escolas públicas. Para o maior proveito da vantagem assim oferecida à população católica, o Bispo esperava que surgissem novas obras catequéticas adaptadas às inteligências infantis, facilitando ao mesmo tempo o trabalho do professor e do aluno. Encerrou o prefácio abençoando os que trabalharam para aquela obra didática e recomenda-a a todos que estivessem empenhados na santa cruzada do ensino religioso. ${ }^{95}$

A obra é dividida em três partes. Na segunda parte, há uma apresentação de cada um dos Dez Mandamentos, de forma bastante superficial, sem maiores discussões e com exercícios de memorização e de completar frases com as palavras que faltassem.

As noções de ordem e proibição orientam todas as explicações. Por exemplo, "o Primeiro Mandamento, o que ele ordena?": "O primeiro Mandamento ordena crer em Deus: é a fé; esperar Nele: é a esperança; amá-Lo de todo coração: é a caridade; e não adorar senão a Ele." Mais adiante aparece a questão: "o que proíbe o primeiro Mandamento?" Ao que segue a resposta: "O primeiro mandamento proíbe o sacrilégio, a profanação das coisas santas e a indiferença. Proíbe ainda a dúvida e a incredulidade, o desespero e a presunção." 96

Logo após encontram-se os Mandamentos da Igreja. Segundo a publicação, "Nosso Senhor deu à Igreja o poder de ditar Mandamentos." O livro apresenta a questão: "o que eles ordenam?" Seguem as ordens da Igreja: ouvir missa aos domingos, a confissão uma vez ao ano, a Comunhão na Páscoa, o jejum e o Dízimo. Após os exercícios, aparece sempre uma leitura, um texto intitulado: A Igreja é Mãe, que afirma: "os cinco mandamentos que acabais de recitar não são os únicos da Igreja. Há muitos outros que se referem aos padres, aos religiosos, aos pecadores; mas todos têm um só fim; fazer chegar ao céu...

\footnotetext{
${ }^{95}$ ARQUIVO DA CÚRIA METROPOLITANA. Texto de Apresentação do Bispo de São Carlos D. Gastão Liberal Pinto ao livro Exercícios Práticos de Catecismo do Pe. Quinet. 04.11.1936. Pasta 06-02-23 Diretoria Arquidiocesana do Ensino Religioso.

${ }^{96}$ ARQUIVO DA CÚRIA METROPOLITANA. Pasta 06-02-23 - Diretoria Arquidiocesana do Ensino Religioso. QUINET, Padre C. Exercícios Práticos de Catecismo: para uso de todas as Dioceses. Tradução de Maria Pacheco e Chaves. São Paulo: Oficinas Gráficas da “Ave Maria”, 1940. p. 50
} 
Certamente já vistes um pastor guardando suas ovelhas; impede-as de comer ervas daninhas, de se afastar do rebanho e de se perder. O Papa, pastor das almas, faz a mesma coisa e todas suas leis visam nosso bem. Crianças, amai muito a Igreja!" 97

A terceira parte do livro trazia ensinamentos sobre os meios de salvação e sobre os Sete Sacramentos da Igreja, igualmente de forma que o aluno decorasse tudo, com exercícios de memorização e fosse sabedor das ordens e proibições, deveres e pecados. No capítulo referente à Confissão, o livro apresentava um pequeno método de confissão, orientando passo a passo o que a criança deveria fazer quando estivesse frente a frente com o Padre. No tocante aos pecados capitais, o aluno era orientado a dizer: "Padre, acuso-me de ter sido orgulhoso... invejoso... guloso... de ter-me enfurecido... de ter sido mau... de ter sido preguiçoso...

Acuso-me ainda de ter pecados de que não me lembro, dos da minha vida passada. Peço a Deus perdão; e a vós, Padre, penitência e absolvição, ou benção" 98

Nas explicações sobre o Sacramento da Ordem, são apresentadas as funções e atribuições de um padre, através de imagens. Segundo a obra, o padre batiza, ensina às crianças a conhecer e a amar a Deus, diz a missa e dá aos fieis o corpo de Nosso Senhor, prega a palavra de Deus, perdoa os pecados e consola os doentes e os ajuda a morrer santamente. Abaixo há a elocução sobre imagens com as seguintes perguntas: "diga o que faz o padre? Desempenha um belo ministério? Gostaria você de ser padre?"

Após alguns exercícios, é apresentada uma leitura ao aluno, com o título Serás Padre! O texto diz: "Ó meu filho, podes, também, ser padre, se sentes em tua alma, em teu pequenino coração, Deus que te reclama. És bem puro, amas a oração, as coisas da Igreja, as belas cerimônias do culto; se quiseres, serás padre."

\footnotetext{
${ }^{97}$ Ibid. p. 35-36.

${ }^{98}$ Ibid p. 78.
} 
Nas explicações sobre o Matrimônio, o livro traz no tópico Doutrina, a seguinte explicação: " o matrimônio é o sacramento que santifica a união do homem e da mulher. O matrimônio é indissolúvel, é rompido só pela morte. $\mathrm{O}$ divórcio é condenado por Deus e pela Igreja."

Na parte dos exercícios de memória, o aluno deveria responder por escrito ou oralmente:

O matrimônio é um sacramento que...

O divórcio é um ... (diga se o divórcio é um pecado muito grave). O matrimônio só é rompido pela...

O matrimônio religioso é o único que... (diga se é o único que tem valor aos olhos de Deus).

No exercício "Frases a Completar" o aluno deveria completar as frases com as seguintes palavras: matrimônio, indissolúvel, pecado, divorciados, comunhão.

O sacramento que santifica a união do homem e da mulher é o...

O matrimônio nunca pode ser rompido; também dizemos que o matrimônio é... A ruptura do matrimônio, que é denominada divórcio, é um grave... A Igreja recusa-se a enterrar os...

Os futuros esposos preparam-se ao sacramento do matrimônio pela confissão e pela... 99

Uma organização bastante articulada, não só na capital como em todo o Estado de São Paulo, através das Diretorias Diocesanas no interior, inspeções frequentes, material didático, formação de professores, escolas públicas como quadros inteiros de professoras católicas, conversões. Todo esse panorama

\footnotetext{
${ }^{99}$ Ibid p. 94.
} 
permite fazer reflexões sobre a relação entre política e religião e os limites de uma escola laica e a participação religiosa.

O jornal Correio Paulistano publicou uma série de artigos do padre Cavalheiro Freire, em resposta a uma coluna veiculada num vespertino de São Paulo. O tópico lamentava a falta de aproveitamento por parte da Igreja Católica da do artigo 153 da Constituição Federal de 1934 e da Lei Estadual 6766 que diziam: "fica incorporado ao regime escolar dos estabelecimentos oficiais de ensino primário, secundário, profissional e normal o 'Ensino religioso'. $\mathrm{O}$ artigo lamentava que com a força arregimentada e gigantesca da Igreja Católica não tivesse aproveitado ainda as recentes legislações. O padre expôs a organização do Ensino religioso em São Paulo, destacando a existência do Departamento Arquidiocesano do Ensino Religioso, bem como a Inspetoria Arquidiocesano do Ensino Religioso, localizadas na rua Venceslau Braz no 38 , que eram subordinadas diretamente ao Arcebispo Metropolitano e dirigidas pelo padre João Pheeney de Camargo e Silva. Para o padre Cavalheiro, Pheeney era um dos membros do clero paulista, a quem o ensino religioso católico devia sua magnífica organização naquele momento.

A partir da resposta, o padre Cavalheiro inicia a publicação de estatísticas de escolas da Capital, sendo a primeira do Grupo Escolar Amadeu Amaral, (estatísticas serão apresentadas em outro momento) e que se seguiram em outras edições do Correio. O padre declarou que cada Diocese do Estado de São Paulo possuía sua Diretoria Diocesana do Ensino religioso que trabalhava em conjunto com o órgão central metropolitano.

A Arquidiocese possuía informações completas de cada estabelecimento de ensino oficial, na parte referente ao ensino religioso oficial, informações que são colhidas periodicamente, sempre levadas a efeito pelo inspetor arquidiocesano sempre nos dias e horas designados no programa oficial para a 
aula de religião. À sombra do Departamento, seria possível aprender muito em matéria de organização, pedagogia, espiritualidade e, sobretudo, grande e sadio patriotismo com o imenso e querido Brasil. Naquele momento, os religiosos falavam muito em patriotismo devido ao contexto da Segunda Guerra Mundial.

O Jornal Correio Paulistano foi fechado pelo governo provisório em 1930 e permanceu sem publicações até 1934. A partir daí, teve diversos proprietários e posicionamentos. De 1937 até 1945, o Brasil viveu o período autoritário do Estado Novo e os jornais foram censurados. Nos anos 40, o impresso notadamente falava bem do governo Vargas, apontando pontos positivos, além de dar grande destaque às notícias da Igreja Católica, e quase nenhum às outras religiões.

Importantes no contexto da discussão, as Atas das Conferências Episcopais da Província Eclesiástica de São Paulo apresentam decisões e projetos, bem como a relação dos bispos e dos Arcebispos Metropolitanos com os políticos. No tópico Propostas concernentes ao Governo Estadual, foi debatido o aumento de tempo do ensino religioso nas escolas. De acordo com a Ata, "é desejo de todos os Sres. Bispos que o ensino religioso nas escolas públicas seja ministrado, no mínimo duas vezes por semana." Se não fosse possível, segundo o relato, que se prolongasse até 45 minutos a aula de religião. Ficou decidido que - Sr. Arcebispo iria fazer uma representação ao Governo do Estado, como também iria pleitear a nomeação de professores para as escolas paroquiais. A Ata apresenta a advertência aos párocos, que deveriam exercer muita vigilância na época das matrículas, para que o desejo dos pais e os interesses do ensino religioso não fossem frustrados pela má vontade dos diretores de escolas. ${ }^{100}$

Outra proposta, que teve a promessa de consulta do Arcebispo de São Paulo ao Governo Estadual, foi a do Bispo de Campinas, Dom Francisco de Campos Barreto. Ele queria que fosse conseguida a nomeação de um lente de catecismo remunerado pelo Governo, ao menos para as Escolas Normais e Ginásios Oficiais. Seguindo-se a Ata de 1939, aparece a ideia de se criar um

\footnotetext{
${ }^{100}$ ARQUIVO DA CÚRIA METROPOLITANA.Ata das Conferências Episcopais da Província Eclesiástica de São Paulo. 28 a 30 de Novembro de 1939. Livro: 08-03-049.
} 
pequeno boletim mensal para orientar os catequistas e uniformizar o sistema de ensino religioso e a proposta para que se obtivesse o reconhecimento do Governo aos diplomas dos religiosos normalistas de outros Estados, pelo menos em favor dos colégios particulares, com a promessa do Arcebispo consultar o Secretário de Educação a respeito.

Além disso, o Bispo de Ribeirão Preto, Dom Alberto José Gonçalves, propôs a criação de um Departamento Central, ou Metropolitano, do Ensino Religioso, com sub-seções nas várias dioceses, para a solução de casos regionais e afeitos às Delegacias do Ensino Público, proposta aceita por unanimidade. Foi marcada, também uma reunião em São Paulo com todos os diretores diocesanos do Ensino Religioso, que deveria se realizar nos dias 27 e 28 de dezembro daquele ano. Nela, seriam discutidos todos os pontos que interessassem e seriam estabelecidas as normas gerais que haveriam de seguir quanto à prática do ensino religioso nas escolas.

Novamente, foi questionada a moralidade do ensino de Educação Física: "Os Exmos. Sres. Bispos foram unânimes em lamentar e condenar os abusos e excessos da educação física, como vem sendo ministrada, hoje, nos estabelecimentos de ensino." Prosseguindo, afirmaram que "constitui verdadeiro atentado ao pudor da mulher e um incentivo à luxúria." Ficou resolvido que este "delicado e importante assunto" seria examinado e estudado por um grupo de sacerdotes competentes, a fim de fazer, nesse sentido, uma bem fundamentada representação ao Governo.

Foi aprovada, segundo a Ata, uma proposta do Arcebispo Dom José Gaspar, no sentido da conveniência de possuírem os Bispos um ou mais códigos para as comunicações epistolares ou telegráficas, de cunho estritamente reservado, já que era vasta a Província e constantes as relações entre os Bispos e havendo, muitas vezes, a necessidade de se fazerem comunicações reservadas.

A Reunião da Província Eclesiástica do ano seguinte, 1940, foi realizada alguns meses após a assinatura da Concordata entre a Santa Sé e a Republica Portuguesa, durante o Estado Novo português, presidido de forma ditatorial por 
Antonio de Oliveira Salazar. O documento visava restaurar a liberdade da Igreja em Portugal, após os acontecimentos posteriores à implantação da Primeira República: separação Estado/lgreja, nacionalização dos bens eclesiásticos, proibição do culto público. A Concordata estipulava o restabelecimento à Igreja dos bens que ainda estivessem em poder do Estado, os efeitos civis do casamento religioso e a consequente renúncia dos cônjuges à faculdade civil do divórcio, a possibilidade das associações e organizações da Igreja estabelecerem livremente e manterem escolas particulares paralelas às do Estado. $O$ ensino ministrado pelo Estado, de acordo com a Concordata, seria orientado pelos princípios da doutrina e moral cristãs, tradicionais de Portugal, com o conseqüente ensino da religião e moral católicas. ${ }^{101}$

Os bispos brasileiros (ao todo 12 participaram da Reunião) queriam a assinatura de uma Concordata entre a Santa Sé e o Governo brasileiro, nos mesmos moldes do acordo português. De acordo com a Ata, "o Episcopado paulista é favorável à Concordata, uma vez que ela se faça com evidentes vantagens para a Igreja, tal como, mutatis mutandis, se fizera com Portugal." $\mathrm{O}$ Bispo de São Carlos, Dom Gastão Liberal Pinto, em conformidade com o pensamento dos outros Bispos, acrescentou que, entre essas vantagens, três deveriam ser pleiteadas como essenciais: os direitos do casamento religioso, o ensino da Religião nas escolas e a personalidade jurídica das Instituições eclesiásticas. ${ }^{102}$

$\mathrm{Na}$ reunião, os Bispos discutiram novamente sobre o catecismo nas escolas, assunto que foi debatido na reunião dos Diretores diocesanos do Ensino religioso, que se realizou pouco tempo antes. Era desejo das autoridades presentes o aumento de tempo para as aulas de catecismo nas escolas, de meia hora para 45 minutos. Segundo o relato do Arcebispo D. José Gaspar, os sacerdotes solicitaram esta medida junto à Diretoria Geral do Ensino. Na mesma reunião, os Diretores diocesanos resolveram também: fundar na Arquidiocese um órgão que orientasse em toda a Província a solução dos problemas atinentes ao

\footnotetext{
${ }^{101}$ Concordata entre a Santa Sé e a República Portuguesa, 7 de maio de 1940. In: http://www.vatican.va/roman_curia/secretariat_state/archivio/documents/rc_seg-st_19400507_santa-sedeportogallo_po.html. Acesso em 20/06/2014.

${ }_{102}$ ARQUIVO DA CÚRIA METROPOLITANA. Ata das Sessões da Segunda Reunião da Província Eclesiástica de São Paulo, 26 a 28 de outubro de 1940. Livro: 08-03-049.
} 
ensino religioso nas escolas; solicitar a fundação em todas as dioceses da Associação da Doutrina Cristã; sugerir aos Senhores Bispos que se mandem imprimir quadros murais catequéticos para maior facilidade do ensino. Segundo a Ata, a Companhia Melhoramentos de São Paulo se dispôs a imprimi-los, à razão de $72 \$ 000$ pela coleção de 50 quadros, se as dioceses entrassem com a quantia inicial de 100:000\$000. Os Bispos presentes aceitaram a proposta desde que a Companhia custeasse as despesas de impressão. ${ }^{103}$

As reuniões da Diretoria Arquidiocesana do Ensino Religioso, tanto de delegadas, professoras e catequistas, quanto dos Diretores e autoridades religiosas, eram anunciadas com freqüência no jornal Correio Paulistano. Algumas vezes, eram publicadas também as decisões tomadas e os principais acontecimentos. Como na edição de 12 de novembro de 1940, em que foi publicada a realização da reunião mensal e que nela foi realizado um sorteio de prêmios entre os benfeitores do Ensino Religioso. O primeiro prêmio foi uma bicicleta Jaguar, o segundo, um relógio pulseira Mundial, o terceiro, um rico jogo de toalhas de chá, o quarto a vida do Santo Cura de Ars. Do quinto ao sétimo, um exemplar de Concordância dos Santos Evangelhos de Dom Duarte Leopoldo e Silva. ${ }^{104}$

\section{Atas do Órgão Central Metropolitano}

Ata da Primeira Sessão

Aos 27/12/1939, na sala S. José do Seminário Central da Imaculada Conceição do Ipiranga, sob a presidência do Revmo. Pe. João Pheeney de Camargo e Silva, diretor arquidiocesano do Ensino Religioso, e com o comparecimento dos Revmos. Diretores Diocesanos infra assinados das Dioceses de Campinas,

\footnotetext{
${ }^{103}$ Ibidem.

${ }^{104}$ Correio Paulistano. 12.11.1940. http://memoria.bn.br/docreader/DocReader.aspx?bib=090972 08 . Acesso em 30.05.2014
} 
Ribeirão Preto, Taubaté, Sorocaba, Santos, Botucatu, Bragança, Assis, Rio Preto, Cafelândia e Jaboticabal, foi aberta a sessão (...) foi dada a palavra ao secretário, que esta subscreve, para ler, as referidas sugestões episcopais. Terminada a leitura, entrou em debate a definição do que se entende por Ensino Religoso, que após ouvida a palavra de cada um dos congressistas, ficou assim redigida. Entende-se por Ensino Religioso a exposição racional dos princípios da doutrina cristã para formação religiosa do homem. Por exposição racional subentendem-se os métodos, modos e processos ativos e eficazes da explanação dos Dogmas, Orações, História Sagrada, Moral e Liturgia, de cujo aprendizado resulta a formação religiosa do educando. Como corolário, a seguir, ficou assentada a orientação a ser recomendada nas primeiras comunhões; que ficou resumida assim: a primeira comunhão será feita, a juízo do Pároco quanto ao preparo das crianças e em harmonia com os professores do ensino religioso e das catequistas da Paróquia, de preferência na Matriz; devendo prevalecer o critério da melhor qualidade de preparação dos neo-comungantes e não do número elevado, evitando-se, desse modo, o inconveniente geralmente apontado e reprovado das Primeiras Comunhões em Massa. Nesse momento foi a sessão interrompida pela chegada de S. Excia. Revma. O Sr. Arcebispo Metropolitano, que disse aqui se encontrar para dar-nos sua bençam (sic), lembrando-nos que nossa tarefa não era a de fazer poesia mas de realizar um trabalho enquanto possível concreto, completo e eficiente. Ao retirar-se, convidou-nos para uma reunião em palácio amanhã às 17 hs. e para o jantar em sua companhia. Reiniciada a sessão, foi posta em discussão a organização dos Órgãos dirigentes do Ensino Religioso, ficando depois de vários debates assim determinada: Órgão Metropolitano a cargo do Diretor Arquidiocesano; Órgão Diocesano, a cargo do Diretor Diocesano; Órgão Paroquial a cargo do Pároco; Órgão escolar a cargo do Inspetor do Ensino, cujas atribuições ficarão assim distribuídas. Ao Órgão Metropolitano compete entender-se com as autoridades governativas do Departamento do Ensino Público; tratar da preparação e distribuição do material catequético para todas as Dioceses da Província; enviar anualmente um questionário aos Diretores Diocesanos para verificação da eficiência do Ensino e dar-lhe a devida publicação para o fim de correção e melhoramentos julgados necessários. Ao Órgão Metropolitano lembramos a necessidade de se dar um secretário e um tesoureiro, 
como requerem as suas atividades. Ao Órgão Diocesano compete nomear, por indicação do Pároco, os Inspetores e professores do Ensino Religioso. Pois para obviar a vários inconvenientes, como seja, nacionalidade, incompatibilidade, etc, sugerimos a necessidade de serem nomeadas pessoas leigas, de preferência ao Pároco, que será, por força de seu cargo, a autoridade religiosa em sua Paróquia, independente de qualquer outra nomeação de requisitos legais não eclesiásticos, cabendo-Ihe, pois, como Órgão Paroquial o direito e obrigação de indicar pessoas para Inspetores e professores das escolas públicas de sua Paróquia, bem como a zelosa fiscalização de como se desempenham de seus deveres no magistério do ensino religioso, que fará, semestralmente, um relatório que será enviado ao diretor do ensino diocesano, juntamente com o do sodalício da Doutrina Cristã. Outrossim, é de toda conveniência seja obtida do Governo a faculdade de o Diretor diocesano nomear englobadamente, e para lecionar aonde quer que seja, na zona escolar a que pertencem, as professoras do ensino religioso, o que corresponderia à economia de muitos reconhecimentos de firma e a maior regularidade do ensino no caso de transferências de uma escola para outra escola da região. Entende-se nomeação de todas as professoras, tanto rurais como urbanas, porquanto o título de nomeação ficará na Delegacia Regional de Ensino e a cada professora se há de conferir uma ficha de identidade, ambos de acordo com o modelo uniformizado e aprovado pelas autoridades competentes. Ao Órgão escolar compete fiscalizar a nomeação de professoras, a pontualidade e horário das aulas, assim como a execução racional e conscienciosa do programa, de tudo quanto prestará contas ao Pároco quanto solicitado, quanto o exigirem circunstâncias especiais. Quanto ao Programa, sem dispensar 0 Catecismo Diocesano, ficou resolvido que se adote, a título de experiência o texto do Pe. C. Quinet: Exercícios Práticos de Catecismo e Meu Caderno de Instrução Religiosa, para trabalhos a serem metodicamente feitos em casa. Para os cursos Fundamental, Profissional e Normal, preconizamos, do mesmo autor, os Apontamentos de Catequista, sendo de notar que, para o segundo ano das Normais, seja a sua explanação feita de tal modo que, ao mesmo tempo que a doutrina, aprendam as professorandas a didática do catecismo, não se descurando, aqui e ali, da parte apologética nos pontos referentes a assuntos de maior atualidade, como divórcio, liberdade, religiões, etc. No que se refere à 
Liturgia que está em preparo, para breve, uma fácil exposição de acordo com as lições do texto adotado, cuja explicação está confiada ao critério pedagógico e ao zelo das Sras. Professoras, em toda a sua extensão, sob as luzes das autoridades catequéticas e ao calor do amor de Jesus, que é o caminho, a verdade e a vida de todos os homens, mas principalmente de professores e alunos. Sugerimos o mesmo programa para o Sodalício da Doutrina Cristã, que naturalmente já funcionava nas paróquias e para o qual existe uma comissão encarregada de preparar o material catequético indispensável, e que, na medida do possível, se esforçará para, em breve, fornecê-lo aos Revmos. Párocos. No que concerne aos itens sobre reconhecimento de diplomas, nomeação de professores para cursos superiores e obrigatoriedade por lei de ministrar o ensino religioso, salvo melhor juízo, considerando as modificações a serem pleiteadas e de imediata necessidade: considerando a próxima reforma do ensino primário oficial e a delicadeza do assunto opinamos para que se aguarde melhor oportunidade.

Ata da Segunda Sessão

Aos 28/12/1939, na sala idem a primeira às oito horas e meia, foi aberta a sessão com a recitação da Ave Maria...

Dada a palavra ao secretário foi lida a ata da sessão anterior que, posta em discussão, foi aprovada. Foram lidas também cartas congratulatórias e de bênçãos dos EXmos Srs. Bispos de Campinas, Assis e Jaboticabal e do Vigário Geral de São Carlos, apresentando sugestões. A seguir, voltou à consideração dos presentes o assunto das Escolas de formação de catequistas. Da nova e ampla discussão sobre tão momentosa questão, ficou deliberado o que segue. Inegavelmente é de inadiável solução a formação de catequistas. Como, porém, é de mui complexa dificuldade, qualquer medida definitiva deve ser adiada antes de uma experiência indicadora, que serve de base para a sua adoção. Por isso, foi sugerida esta orientação a respeito: nos cursos obrigatórios de Religião administrados aos congregados marianos, filhas de Maria e Membros da Ação 
Católica, e facultativos às demais pessoas que desejem frequentá-los, o Diretor, o Pároco, ou quem deles se encarregue, escolherá os mais capazes, em preparo e disposição para o Magistério catequético, para freqüentarem aulas especiais de didática do catecismo. Talvez, assim, no fim de um ano, com aulas semanais para uns e outros se formem catequistas capazes de lecionar o programa dos primeiros anos. Isto entretanto não deve substituir as verdadeiras escolas de catequistas, que já existem em algumas Dioceses e que merecem todo louvor e apreço. Como texto para aqueles cursos de religião pode ser dado ao aluno o que se encontra no livro Apontamentos do Catequista, do Pe. Quinet, ou em qualquer outro da escolha do professor. Dos resultados colhidos, aparecerá o que se possa aconselhar para uma adoção geral e oficializada na próxima reunião dos Exmos. Diretores Diocesanos.

Quanto às dificuldades encontradas em algumas zonas, na aplicação dos dispositivos do Decreto 6.766, adotou-se a presente orientação de se recorrer ao espírito conciliador do Artigo 8o do mesmo Decreto, a fim de se evitarem interpretações clamorosas e prejudiciais. Para isso, foi sugerida a ideia de reuniões, com fins educativos e sociais para as quais sejam convidadas as autoridades eclesiásticas e do magistério, o que certamente fomentará a união de pontos de vistas nascida do amistoso convívio das partes. O uso de se ostentar o crucifixo durante as aulas de religião deve ser recomendado, bem como se realizem impressionantes cerimônias religiosas no encerramento do ano letivo. Tenham lugar de destaque, pela sua significação, entre outros trabalhos escolares expostos, os executados nas aulas de religião; como centros de interesses, gráficos, mapas, etc. de cunho religioso educativo e não meramente piedoso. Assim também mereceu aprovação a ideia de na distribuição de prêmios escolares, serem conferidos os de religião pela autoridade eclesiástica ou quem faça suas vezes. Os trabalhos expostos sejam conservados desde já com o fim de se formar o Museu catequético, donde colheremos o material necessário para a grande exposição catequética por ocasião do Congresso Eucarístico. Ficou escolhido para Dia do Catecismo, o $1^{\text {o }}$ domingo do mês de junho de cada ano, comemoração essa prescrita pelo Decreto "Provide sane consilium"; além disso, aproveitar-se-á a oportunidade do dia da Elevação Espiritual, na Semana da 
Criança, para um trabalho religioso com as crianças. A seguir, os Diretores fazem os mais ardentes votos porque se possa contar, cada vez mais, com a eficiente e zelosa colaboração dos Revmos. Religiosos e Religiosas no campo catequético, o que muito contribuirá para se alcançar o resultado esperado na doutrinação das crianças do povo em geral, pois serão os seus trabalhos de grande auxilio aos Revmos. Párocos, nessa grande jornada catequética pela libertação das almas das garras da ignorância religiosa. Desejam, também, não se veja nestas sugestões de ordem técnica a exclusão daquela outra parte do ensino, que consiste na formação espiritual dos catequistas qual seja o ideal de apostolado, 0 espírito de abnegação e dedicação constantes, alimentadas pelo amor de Deus e das almas, sem o que, como conhecemos de sobra, nada podemos fazer e dana será feito. E como de sobejo reconhecem todas essas qualidades nos zelosos Párocos da Província, confiam que o seu zelo há de ser o fator decisivo para todas essas realizações, tão desejadas pelos Exmos Srs Arcebispos e Bispos diocesanos, que aí estão como modelos dessa Fé viva, que se multiplica nas mais variadas obras de salvação das almas. Para sinal de união e identidade de vistas e de boa vontade, ficou adotado um só carimbo oficial para as Diretorias do Ensino Religioso e, enquanto não circular a revista Anchieta, será o Legionário, valoroso órgão católico o porta-voz do Órgão Metropolitano. Tomadas essas resoluções de um modo geral, muitas ainda ficam a serem estudadas, pois a carência de tempo e a prudência não permitiram sinão (sic) a concretização dos pontos básicos da momentosa questão catequética, o que certamente de modo muito melhor hão de outros fazer no futuro, e de maneira mais completa e aprimorada. Ao encerrar dos trabalhos, Mons. Loschi, em nome de todos agradeceu ao revmo. Sr. Presidente a prudência, sabedoria e piedade com que se houve na direção dos trabalhos. S. Revma agradecendo externou seus sentimentos de gratidão e admiração e gratidão para com os seus colegas, que muito o edificaram com seu espírito de humildade e zelo pela causa de Deus. Finalmente, ficam aqui registrados os agradecimentos dos Padres Diretores Diocesanos aos Revmos Pes. Reitor e Ministro deste Seminário, que tão gentil e generosamente os acolheu, extensivo aos bondosos seminaristas. Nada mais havendo a tratar, encerrou-se a sessão com a recitação de três Ave Maria em ação de graças. Lida e aprovada, vai por todos os presentes assinada. 
São Paulo, 28 de dezembro de 1939.

Ata da terceira e última sessão

Às dezesste horas e trinta minutos, dia 28 , no Palácio S. Luiz, sob a presidência do Exmo. Revmo. Sr. Arcebispo Metropolitano, reuniram-se a convite de S. Excia. Revma. Os revmos. P.P Diretores do Ensino Religioso da Província de S. Paulo, para apresentações do resultado dos trabalhos realizados nãos dias 27 e 28 do corrente. Lidas as atas pelo secretário, foram aprovadas por S. Excia. Revma., que, a seguir, manifestou a sua grande satisfação por receber os Revmos Directores Diocesanos do Ensino Religioso e tomar conhecimento dos trabalhos realizados nessa primeira reunião, declarando esperar recebê-los novamente na próxima reunião que ficou marcada para Novembro futuro. Essa satisfação, disse o Sr. Arcebispo, nasce da crítica que tem do quanto são benéficas, para todos, ? fermentar de ideias e opiniões, porquanto nos habituam a pensar coletivamente. Não dos devem, também, desanimar os contratempos que encaminharmos na execução dos planos delineados, porque pouco a pouco é que se aperfeiçoam essas obras. Sejamos, portanto, humanos no julgamento dos que não satisfizeram plenamente nossos desideratuns, porque já fizeram muito bem na sua vida passada. Desse pensar e desse julgamento, muito lucrará a união entre os que trabalham para a maior glória de bens. Lembram-se, então, das grandes impressões que tanto o comoveram no Concílio Plenário e na última reunião dos Srs. Bispos da Província, pelos magníficos exemplos observados entre tantos e venerandos Bispos, veiculo todos na mais íntima união para a própria salvação e salvação (sic) das almas. Podemos reunir a bela alocução de S. Excia Revma no seu lema querido: alt ournes umem suit é o que transfiro do coração apostólico de S. Excia e que almeja ardentemente ver realizado no seio do clero e de todos os fiéis de sua Arquidiocese e das Dioceses sufragâneas. Quando toda a boa vontade em receberem, sempre que desejarem, os P.P. Diretores do Ensino religioso, para seer tratado assunto de critério da salvação 
das almas, pediu muito o recomendassem os Srs. Bispos Diocesanos dos quais solicitamos as preciosas bênçãos e orações e abençoando os presentes.

Segunda reunião

Aos quatorze dias do mês de Novembro do ano do nascimento de Nosso Senhor Jesus Christo de mil novecentos e quarenta no Seminário Central do Ypiranga em São Paulo, reuniram-se pela segunda vez os Diretores Diocesanos do Ensino Religioso desta Província Eclesiástica. Presidem a sessão e dirigem os trabalhos o Revmo. Pe. João Pheeney de Camargo e Silva, Diretor Arquidiocesano; foi pelos presentes escolhido para secretário o Revmo. Mons. Ramon Ortiz, Vig. Geral da A. C. e Ensino Religioso da Diocese de Taubaté. Tomaram parte na reunião mais os Revmos. Srs. Mons. João Loschi, Vigário Geral da A. C. na Diocese de Campinas, Mons. Ruy Terra (?), Vigário Geral da Diocese de São Carlos, Monsenhor Aristides Silveira, da Diocese de Jaboticabal, Monsenhor Bráz Baffa, da Diocese de Rio Preto, Cônego Agostinho Colturato, da Diocese de Botucatu, Cônego Francisco de Assis Barros, da Diocese de Ribeirão Preto, Pe. Antonio Velasco Aragon, da Diocese de Assis, PE. Luiz Gonsaga dos Santos Pereira, da Diocese de Santos, Pe. Eduardo Rebouças da Diocese de Cafelândia e Pe. Ros(?) de Schaetteuer (?), O.S.B. da Diocese de Sorocaba.

Iniciados os trabalhos após as orações convenientes, o Revd. Pe. Presidente fez ligeiro retrospectivo dos trabalhos da reunião de 1939 e apresentou um plano dos assuntos a serem tratados nesta. Leu o contrato feito com a Editora dos Exercícios Práticos de Catecismo de Quinet, cujo produto pecuniário seria assim distribuído: à Editora $40 \%$, à tradutora $20 \%$, ao Orgam Central Metropolitano 10\%, a cada um dos Orgams Diocesanos 30\%. O preço de venda de cada um dos três volumezinhos da obra ficou fixado em $1 \$ 000$ (mil réis) e a expedição seria feita frete a pagar a cargo dos Orgams Diocesanos. Confirmou-se a deliberação anterior de ficarem os referidos Exercícios Práticos de Catecismo como programa e texto de Ensino Religioso em todas as escolas primárias da Província. 
Foi debatido o assunto referente à matéria da primeira Comunhão, ficando deliberado adaptar-se uma fórmula mais resumida do Acto de Contrição e seria apresentada aos Srs. Bispos uma sugestão sobre isto. Seria também sugerido aos Srs. Bispos tratar-se de difundir em linguagem mais ao alcance das crianças o Primeiro e o Segundo Catecismo da Doutrina Cristã. O mesmo se fará quanto aos Exercícios Práticos de Catecismo à medida que a experiência o aconselhar.

Foi proposto e aprovado que se destine uma parte dos supra mencionados $30 \%$ do Órgão Diocesano ao Órgão Paroquial, ficando a critério de cada Diretor Diocesano o quantum destinado aos Párocos na compra de livro de texto.

Foi lido um oficio do Departamento de Educação, a propósito do acréscimo de uma aula de catecismo de 30 (confirmar) minutos nas escolas públicas. Tendo sido mal interpretado o pedido, ficou assinte voltar-se à carga. Ficou encarregado o Revdo. Cônego Francisco de Assis Barros de redigir o novo oficio e apresentar sugestões ao órgão competente no Rio de Janeiro, visto se cuidar atualmente de unificação de ensino sobre base federal.

A exemplo do que se faz na Delegacia Regional de Campinas, foi ventilada e aprovada a proposta de pedir uma determinação do Departamento de Educação no sentido de ser transferida a aula de Catecismo nas escolas para o dia antecedente ou subseqüente quando o dia de ensino religioso for feriado de maneira a haver sempre a aula semanal de Religião.

Trataram-se as diversas questões referentes a Ginásios. Entre outras a de se solicitar do Deparetamento de Educação que se aplique a estes estabelecimentos o que se faz nas escolas primárias a respeito do pedido de ensino religioso, excluindo sempre a necessidade de sello no representante quando esta se faça.

Deliberaram os Diretores Diocesanos lembrar aos Srs. Bispos a necessidade de cuidar dos uniformes para educação física, enviando ao Rio um emissário para tratar do caso junto à Comissão encarregada do assunto.

Lembrou-se a organização em todas as paróquias da Congregação da Doutrina Cristã. 
Resolveu-se publicar em março próximo e nos anos seguintes uma estatística global de Ensino religioso na Província. Para este fim cada Diretor Diocesano deverá enviar os seus dados ao Órgão Central até 15 de fevereiro de cada ano, a começar de 1941.

Foi debatido o seguinte problema dos quadros murais. Leram-se três cartas da Companhia Melhoramentos de S. Paulo apresentando propostas que ainda precisam de mais acurado estudo.

Seria externado ao Diretor do Departamento de Educação o desejo de que nos saguões dos estabelecimentos de ensino público se coloque o Crucifixo. A fim de concretizar esta proposta e a outras mencionadas na presente ata, os Diretores Diocesanos iriam incorporados visitar o Sr. Pe. A. Romano Barreto, falar-Ihe pessoalmente sobre os diversos assuntos e apresentar-Ihe por escrito as propostas.

Foi ainda objeto de estudos o prosseguimento da publicação do boletim Anchieta. Resolveu-se publicar futuramente dois números anuais: um em março, outro em julho.

O Órgão Central de Ensino Religioso na Província ficou constituído pelos representantes da Arquidiocese, das Dioceses de Campinas, Taubaté e, possivelmente, Botucatu, com o compromisso de reunir-se uma vez por ano, além da reunião geral.

Pelo presidente, foi transmitido aos Diretores Diocesanos o delicado convite do Exmo Sr, Arcebispo para jantar no Palácio S. Luiz.

Foi formulado pelos presentes um sincero agradecimento ao Revd. Pe. João Pheeney de Camargo e Silva pela maneira digna como se desempenhou de sua incumbência. Quiseram também todos que se consignam na ata o sentimento de gratidão para com o Revd PE. Reitor e seus colaboradores pelas gentilezas com que distinguiram os Diretores Diocesanos do ensino Religioso. 
Atas das reuniões do Episcopado da Província Eclesiástica de São Paulo

Quarta Conferência Episcopal da Província Eclesiástica de São Paulo. Ata das Sessões realizadas na sala capitular do Mosteiro de São Bento em São Paulo, de 24 a 26 de novembro de 1942.

\section{Ensino Religioso}

O Sr. Bispo de São Carlos lê o seu parecer sobre o programa do ensino religioso nas escolas oficiais, trabalho de um inteligente sacerdote da Diocese de Campinas, e o parecer se resume no seguinte: a) não abolir o texto do catecismo, por causa dos termos técnicos e tendo em vista a unidade do ensino em toda a parte; b) formar boas catequistas que saibam eficientemente ensinar a mais bela e importante disciplina; c) acrescentar ao programa a História da vulgata e a História Eclesiástica. Unanimemente aprovado o parecer, delibera-se mandar imprimir o programa bem como um livro de texto segundo o programa, ficando encarregado desta parte o bispo de Campinas, que confiaria o trabalho ao próprio autor do Programa, Sr. Cônego Dr. Emílio José Salim, ficando este com os direitos autorais da primeira edição.

Dia 25: O Crucifixo nas escolas

Esta cerimônia feita com muito brilho quando secretário da educação o dr. Álvaro Guião, que com o dr. Mário Alvim, quando convidados, compareceram ao ato, dando assim com a honrosa presença e com a palavra eloqüente grande realce à tocante solenidade. Com o advento do Dr. Rodrigues Alves Filho houve bastante oposição, o que também, com admiração se notou pelo ensejo extraordinário do Congresso Eucarístico Nacional, quando ? se esperava a atitude de homem católico. Com a saída agora deste secretário e nomeação do Dr. Teotônio de Barros, muito conhecido e amigo do Exmo. Sr. Bispo de Ribeirão Preto, recebeu o Sr. D. Lafaiete o encargo de falar com o Sr. secretário da educação, 
cumprimentando-o outrossim, por motivo de ter dado ao $1^{\circ}$ Grupo Escolar de Rio Preto o nome do saudoso Cardeal Leme e o Sr. Bispo de São Carlos sugere que se fale sobre as vestes inconvenientes de alguns professores.

\section{Espiritismo e Protestantismo}

Em seguida, trata-se do problema do espiritismo e protestantismo na Província Eclesiástica, tendo os srs. Padres Agnelo Rossi e Vicente Lioni, ambos do Seminário Central da Imaculada Conceição, feito interessantes trabalhos, salientando-se o mapa de cada Diocese, com sinais gráficos, mostrando o desenvolvimento dessas heresias na Província Eclesiástica. Fato auspicioso de 1942 foi o fechamento da Rádio Piratininga, que excluída por ocasião do Congresso Eucarístico Nacional, das irradiações feitas por todas as outras estações emissoras, foi perdendo completamente o prestígio e no dia 19 de outubro último foi cassada a licença para funcionar, tendo antes chegado ao ponto de ser obrigado a vender o prefixo e não podia ser arrendada como fez, à Federação Espírita. Foi, no entanto, comprado o prefixo pelos srs. Oduvaldo Viana e Júlio Cossi (aquele célebre teatrólogo) que, com o nome de Rádio Panamericana, ambos pretendem, basicamente, com grande e atraente programa, começar as irradiações. É preciso estar de sobreaviso porque o primeiro supramencionado é chefe dos espíritas da corrente cientista, sendo o segundo diretor da Eclética, organização de publicidade.

Na estatística de 1942, declara-se que há dez milhões de espíritas no Brasil, sendo nove milhões de analfabetos, motivando a resolução de abrir muitas escolas.

Já estão aparecendo diversas seitas, sendo as principais os kardecistas, anti-kardecistas, fluidistas, cienticistas. O fim de todas é lutar contra a Igreja 
católica, por meio de intensa propaganda. No jubileu do Santo Padre Pio XII ocorrido este ano, em Uberaba, fizeram lamentável campanha, a ponto de ser extinguida (sic) a revista espírita, por ordem expressa do Governo. Há múltiplos meios de propaganda, como por exemplo a Federação espírita, Sociedade Filosófica que publica a revista "O Pensamento", Sociedade Metapsíquica, Livraria Editora espírita, departamento feminino que promove o Natal com distribuição de roupas etc., departamento de propaganda, com 15 revistas e jornais e delegados de confiança em cada cidade; campanhas diversas como enxoval para noivas pobres, bebês, anti-alcoolismo, Congresso em Buenos Aires e planejam um Congresso Pan- Americano, multiplicação de centros até em fazendas, para o ensino de doutrina espírita. Remédios: vários são sugeridos, como falar aos padres que promovam missões, semanas eucarísticas, citando-se o exemplo de Tremembé, que alcançou grande número de homens para a mesa eucarística. Congresso Eucarístico nas dioceses periodicamente, pois foram palpáveis os resultados em todos estes Congressos, atingindo o apogeu no Nacional. Fica deliberado que em 1946 haverá o $2^{\circ}$ Congresso de Campinas, e em 1948, de Rio Preto. Ao terminar, lembra-se a determinação do Sr. chefe de polícia, baixando portaria contra o espiritismo, porque, com pretexto de espiritismo, havia tramas comunistas. 'Diretrizes', revista espírita, traz o plano dos espíritas de fundar hospitais e declara que no presente ano foram fundados setenta e quatro centros.

Relatório Protestante

A I.N.D.F. filial de São Paulo, apresenta meticuloso trabalho sobre atividades protestantes nas diversas dioceses, salientando os pontos que tomam para combater a Igreja, em São Paulo, há um movimento de cisão com a Nova Igreja Cristã, que procura atrair a elite intelectual. A Igreja Batista Russa usa de vistosa orquestra como meio de propaganda como exercício de salvação, com o clangar dos instrumentos metálicos. Os protestantes reconhecem o valor da Ação Católica e procuram imitar essa genial organização e dizem que os católicos fracassaram pela falta de entusiasmo, competência e brigas individuais. A Escola dominical com suas diversas seções é verdadeiro plágio da A.C. 
De fato, havia a atuação das escolas dominicais na cidade e em 1933 houve uma convenção dessa instituição. Realizou-se, a 29 de abril, a segunda sessão da II Convenção das escolas Dominicais do Estado de São Paulo, na Igreja Presbiteriana Unida, na rua Helvetia № 106. A estatística mundial, segundo a publicação, acusou 410 mil escolas dominicais, 3 milhões de professores e 33 milhões e seiscentos mil alunos. "O acréscimo maior de alunos tem-se verificado nestes últimos 4 anos na América Latina e que foi de 3 milhões e quinhentos mil alunos, 21\% do acréscimo mundial." Em 1932, existiam no Brasil 2.159 escolas dominicais, 8.628 professores e 113.767 alunos, não estando incluída a estatística de São Paulo, que acusa uma média de 500 escolas com 30 mil alunos. Na Convenção propriamente dita foram discutidos tópicos sobre o ensino, ficando estabelecido que a criança devia receber o ensino na escola para haver maior interesse; que as histórias devem ser bíblicas e, quando leigas, só deviam ser narradas para ilustrar a lição bíblica, que não deviam ser lidas as histórias, mas a professora devia narrar em linguagem simples e acessível à criança. Foi também resolvido que houvesse um concurso premiado para as melhores lições que fossem escritas para ensino religioso das crianças. $O$ ensino devia ser ilustrado com mesas de areia, bonecos, desenhos, quadros murais, quadro negro e estimulado com cartões de freqüência, estandarte, boletins aos pais, figurinhas, devendo variar para não se tornar monótonas e despertar maior interesse. No Estado de São Paulo existiam cerca de 30.000 alunos matriculados. 105

Outros perigos

${ }^{105}$ O Estado de S. Paulo 03.05.1933_pág. 4. A II Convenção das Escolas Dominicais de São Paulo. 
É preciso estar de sobreaviso para na ocasião oportuna avisar o clero sobre a atividade espírita da radio Pan Americana que promete para muito breve os seus falados programas. A maçonaria brasileira, condenada por Pio IX, há pouco fechada, agora recomeça suas perniciosas atividades. Há também a organização cognominada 'bucha', também espécie de maçonaria está reaparecendo constando que o próprio reitor da Universidade a ela pertença; é provável que a Fundação Anchieta para manutenção de estudantes pobres, seja de iniciativa maçônica.

Imprensa

Meio apto para combater estes inimigos da Igreja é a imprensa católica e há elogios ao 'Legionário' hebdomadário dirigido pelo Sr. presidente da junta arquidiocesana da A.C. e que já possui tiragem de nove mil exemplares e vai sempre em contínuo progresso.

Última reunião - dia 26

Religiosas

Como há diversas casas de religiosas que usam nos seus escritos, nos atos da comunidade orações e leituras em língua estrangeira, é resolvido que se faça uma circular às religiosas da Província proibindo esta prática inconveniente, bem como chamando a atenção sobre os exercícios de ginástica, bailes de formatura, avisando-se da exclusão da parte religiosa do programa, caso promovam as alunas tais festas profanas inteiramente contrárias ao espírito da Igreja. Haja, outrossim, a transcrição daqueles decretos que o C.P.B. ordena a leitura (...) 


\section{Vários assuntos}

É preciso acautelar os fiéis a respeito da Cruzada Nacional de Educação que é obra genuinamente protestante.

\section{Quinta Conferência Episcopal da Província Eclesiástica de São Paulo realizada no Palácio São Luiz, de 22 a 24 de abril de 1945 às 15 horas.}

Política: É delicada a situação atual do país e os Exmos srs. Núncio Apostólico e Dom Jaime de Barros Câmara esperam o Código Eleitora para resolver o estabelecimento da Liga Eleitoral Católica. Os candidatos para a presidência da República ambos são católicos e todos têm ampla liberdade na votação. A maior dificuldade será para a eleição da Câmara e do Senado e nesta ocasião haverá normas para os católicos.

Carta Pastoral: a fim de orientar os fiéis sobre a Doutrina da Igreja a respeito do governo civil, os exmos Srs. Bispos Norte-americanos publicaram Carta Pastoral, cujo resumo foi apresentado pelo Exmo. Sr. bispo de São Carlos. O exmo. Sr. Arcebispo, de acordo com os srs. Bispos, acha conveniente a publicação de um documento semelhante para orientar os diocesanos, principalmente a respeito do comunismo, que pode ser ateu (o que é condenado) ou não, tendo neste caso a sua parte aproveitável. Para a formação desta consciência nacional nada melhor do que a catequese; a instrução, a Universidade Católica para formar os futuros estadistas, que não farao governo católico se não forem catolicamente formados. Os exmos. Srs. Arcebispo e Bispo de Campinas, Sorocaba e São Carlos constituem a comissão para organizar, redigir e publicar a Pastoral Coletiva. 
A sessão da tarde inicia-se com a leitura de um artigo contra o Vigário Capitular de São Luiz do Maranhão, por não ter S. Revma. Atendido o convite para a celebração da Santa Missa em sufrágio da alma do Presidente dos Estados Unidos, Franklin Roosevelt. Protestante durante a vida não é possível fazê-lo católico após a morte. Por maiores benemerências que tenha feito não é esta a homenagem que se deva prestar ao ilustre estadista, pois as preces públicas da Igreja são para seus filhos.

Rotari Clube: A organização protestante maçônica do Rotari Clube continua infestando a Província Eclesiástica e a direção central chega a ponto de convidar o próprio Bispo Diocesano para a inauguração oficial do Clube. Proibido terminantemente ao clero, é reprovável aos católicos, devendo os srs. Párocos e vigários conforme diz o C.P.B., aconselhar os católicos que se abstenham de se alistar nesta sociedade, mas, que se inscrevam na A.C.

IV Congresso Eucarístico Nacional

(Atas das Professoras de Comunhão Infantil)

Reunião presidida pelo padre João Pheeney de Camargo

Ata da $2^{\text {a }}$ Reunião - 28/03/1942 - 16:45 
Salientou a nobreza da missão do professor católico - um dos mais sólidos esteios em que se apóia a Pátria - pois quem na infância é educado para Jesus conserva durante a vida a suave lembrança da sã doutrina colhida dos lábios do mestre, tornando-se sempre útil à família e à sociedade. Frisou o quanto foi eficaz a cooperação do professorado católico não só nos outros Estados do Brasil, mas também nas cidades paulistas onde a comunhão infantil constituiu uma das partes mais belas do Congresso. Bela pela grande piedade e perfeita ordem o que serviu para encantar, edificar e comover até os indiferentes em matéria de Religião! Continuando o Revdmo. Pe. Pheeney preveniu que a tarefa do professorado vai ser ingente (?), vai exigir muito sacrifício e muita abnegação, sacrifício e abnegação que se tornam pequeninos nadas diante da grandeza do Deus a ser homenageado e das extraordinárias graças que Ele distribui por ocasião dos Congressos Eucarísticos. Disse que o plano de trabalho já está traçado devendo cada professor iniciar o preparo de seus alunos, dando-lhes ideia simples e clara do que seja um Congresso Eucarístico, convencendo-os de que a Pátria só é grande, forte e respeitada quando se apóia em Deus e que, quando suas leis são contrárias às leis divinas desaparecem a ordem, a felicidade e a paz. Deve ensinar-Ihes que o Congresso Eucarístico, é uma solenidade religiosa e patriótica, todos os brasileiros dos diversos pontos do País se convergem para, em único local, prestar a Jesus a mais solene homenagem de louvor ardente, fé sincera e adoração respeitosa. Deve dar-Ihes a letra de todos os hinos que devem ser interpretados e decorados e só confiar o ensaio de canto a pessoa de reconhecida competência para cortar vícios e defeitos. Deve recitar com eles o mais frequentemente possível a oração do Congresso, sugerir-Ihes a prática de pequenos sacrifícios e de atos agradáveis a Jesus levando-os assim a merecer, com a maior coma ? de boas ações, a partícula que vai receber e que será consagrada no dia da comunhão geral. A propaganda entre colegas e alunos e o trabalho de preparo das crianças deve ser iniciado já - cada professor em sua classe - dependendo o movimento maior e geral das delegadas, de um entendimento da Diretoria Arquidiocesana do Ensino Religioso com as autoridades escolares. Com autorização oficial, torna-se mais amplo o campo de ação e mais fácil para a delegada à execução das ordem e determinações do Diretor Eclesiástico. Para a circular que deve ser enviada a cada delegada e para 
o ramalhete espiritual das crianças foram apresentadas sugestões que submetidas a novos exames e debates, só serão aproveitadas as que o Diretor Arquidiocesano do Ensino julgar mais úteis e mais convenientes. Antes de enviar a circular o Revdmo. Pe. Pheeney dirige às delegadas a sua palavra de ordem que deseja ver prontamente cumprida. Cada qual deve, com urgência, procurar o Vigário da paróquia a que pertence seu Grupo Escolar e cientificar-se da época das Semanas Eucarísticas. Uma vez ciente, combinar com ele quais as cerimônias em que as crianças devem tomar parte e cooperar para que tudo seja feito com um prévio preparo e com bastante devoção e piedade. Continuando, pede às professoras que convidem as crianças para uma comunhão mais freqüente, semanal se possível, com o fim de glorificar a Jesus, de pedir-lhe a conversão dos pecadores e a união da Religião e da Pátria para que mais intimamente ligadas possam atrair abundantes bênçãos de Deus. Avisa ainda o Revdmo Pe. Pheeney que um grupo de estações de rádio das quais a Excelsior é a principal, acha-se ligado, em estreita cadeia, para a propaganda do Congresso Eucarísitco. A propaganda entre as crianças foram reservados 15 minutos duas vezes por semana, durante três meses. O revdmo Pe. Veiga do Colégio São Luiz, incumbiu-se de orientar o programa. Serão escolhidos 24 Grupos Escolares para ocuparem o microfone em dias determinados. A escolha recaiu nos grupos mais centrais ou naqueles que apresentarem maior probabilidade de êxito na exceção do programa. Compete à delegada entender-se previamente com o REvdmo Pe. Veiga, escolheu o colega e o aluno que devem representar o estabelecimento, promover um ensaio de locutores nos estúdios da Rádio Excelsior, providenciar para que haja aí, no dia da irradiação um grupo de ouvintes infantis e fazer a propaganda entre professores e alunos para que todos sintonizem seus aparelhos na hora que Ihe foi reservada. Em se tratando de propaganda, acrescenta 0 Revmo PE. Pheeney, deve ficar patente que só entrarão no recinto do Congresso, a 5 de setembro de 1942, crianças de 7 a 14 anos devidamente identificadas e os professores responsáveis por elas. Para isso, ser-lhes-á fornecida uma lista onde cada professor-catequista fará a relação somente de quem já fez a 1ํㅡ Comunhão. Na lista, figurarão o nome do estabelecimento e o do professor, além dos nomes e respectivos endereços das crianças. Uma vez identificada cada qual receberá na véspera da Comunhão e logo após a confissão, um distintivo que será de pano 
forte, como símbolo do Congresso tendo no verso lugar para o nome e o endereço, tanto do estabelecimento de ensino como da residência do portador. $O$ uniforme será branco, de manga comprida, sapato de couro, não sendo permitido o uso de tênis. Cada menina deverá ter seu véu preso por fita ou elástico. Em se tratando do 'lunch' nada ficou resolvido. (...)

Ata da terceira reunião das professoras encarregadas de promover a Comunhão Infantil por ocasião do IV Congresso Eucarístico Nacional de São Paulo.

04/04/1942 - 15:30 - Colégio das Cônegas de Sto. Agostinho

Reunião convocada pela Diretoria Arquidiocesana do Ensino Religioso

Compareceram algumas dezenas de professores católicos e comissão encarregada de promover a Comunhão Geral das Crianças.

O Revmo Pe.Pheeney, considerando que muitos dos assistentes delegados do Ensino Religioso nos Grupos Escolares só tinham ficado a par do movimento em prol da Comunhão infantil pela leitura da ata abordou novamente o assunto como se tratasse da reunião preparatória. Frisou a grande responsabilidade do professor católico diante do Cristo Nosso Senhor, agora que São Paulo em peso, unido pelo mesmo espírito de fé, movimenta-se coordenando esforços e energias para prestar-Ihe como Verdadeiro Rei, culto de veneração e amor. Espera que cada professor católico se torne um verdadeiro apóstolo para conquistar todos os colegas, primeiramente rezando e implorando a proteção divina, depois convidando-os com insistência ou arrastando-se com a força irresistível do exemplo. Salientou que do trabalho dos professores depende o êxito da comunhão das crianças no dia 5 de setembro de 1942. Faz questão que os meninos participem ativamente de tudo, pois é muito comum ver-se a seção masculina com um deficiente número de representantes. Claro está que o 
númerode comparecimentos será graça concedida por Nosso Senhor. O que S. Excia Revma o Sr. Arcebispo quer e ele Diretor do Ensino Religioso, recomenda com insistência, é o necessário preparo. O trabalho dos professores catequistas este ano deve visar o Congresso e, portanto, girar em torno do Sacramento da Eucaristia. A parte espiritual deve sempre predominar. Se for possível conciliar quantidade com qualidade será o ideal. A Comunhão geral será no Parque Anhangabaú e, contará, por certo, com assistência extraordinária. Poderá constituir espetáculo belo e empolgante se a piedade e a ordem predominarem durante toda a solenidade religiosa. Para atingir-se esse edificante resultado cumpre instruir devidamente as crianças para tomarem parte ativa nos preparativos para a realização do Congresso de modo que do movimento que se opera agora na Capital fique na consciência infantil marca indelével. As seduções do mundo com todo seu cortejo de males poderão desviar o homem de amanhã da senda da virtude, da prática da Religião, mas se o trabalho educacional de agora tiver sido eficaz, a alma voltará, por certo, arrependida e humilhada ao seio da Igreja, pois o germe implantado na infância, decide a sorte do indivíduo na hora decisiva do triunfo do Bem ou do Mal, conforme provam inúmeros exemplos. Lembrou sua Revdma. que o ramalhete espiritual a ser brevemente distribuído, será um ótimo meio de integrar o coração e a inteligência da criança no movimento pró-realização do Congresso eucarístico. Cada sacrifício pequenino, cada ato de amor, cada dever alegremente cumprido, será anotado pela criança que, orientada com devotamento pelo professor piedoso, fará dia a dia, o preparo místico de milhares de partículas necessárias na ocasião. Assim, para uma partícula são necessários sete grãos de trigo e para a hóstia do sacerdote vinte grãos. Do engenho do professor e do seu grau de dedicação à causa eucarística depende levar a criança a compreender o valor místico de cada partícula e o desejo ardente de prepará-la. É preciso que as palavras do professor brotem da alma dedicada a Jesus para produzirem no coração da criança o devido efeito e, por conseguinte, o necessário preparo para a grande festa eucarística. Exemplificando, disse o Revdmo. Diretor que sete comunhões fervorosas, ou a assistência a sete missas, ou a recitação de sete vezes a oração do Congresso, ou ainda sete sacrifícios podem levar a criança a preparar a partícula que vai receber ou a de qualquer pessoa por ela escolhida. Continuando, lembrou que a 
criança deve saber a razão pela qual os brasileiros se unem de tempos em tempos, em determinado ponto do território nacional para homenagear o Cristo Jesus sob as espécies eucarísticas. Deve saber que o 1 Congresso Eucarístico Nacional realizou-se na Baía onde iniciamos nossa vida cívica: o $2^{\circ} \mathrm{em}$ Belo Horizonte onde o povo simples e bom seguindo as religiosas tradições dos seus antepassados, preparou para Jesus uma festa triunfal, exemplo de esplendor e piedade; o $3^{\circ} \mathrm{em}$ Recife, centro próspero onde os bons católicos unidos em vibrante demonstração de fé e de civismo, deram para o Congresso a soma total de uma boa vontade que por Jesus desconhece tropeços e supera todas as dificuldades. Que dizer à criança pergunta S. Revma, do IV Congresso Eucarístico a realizar-se em São Paulo, o Estado vanguardeiro do progresso, onde tudo atesta movimento e vida? Responde imediatamente; deve dizer-Ihe que o brilhantismo do Congresso dependerá da graça de Deus a atuar no Coração do paulista e que a graça divina é copiosamente concedida a quem a solicita com fervor. Cumpre convencer a criança que ela deve orar e orar muito, pois Deus mais facilmente atende a prece sincera partida do coração inocente. O paulista sempre ousado e empreendedor no terreno material inspirado por Deus, há de empregar o máximo de sua boa vontade e energia pelo Cristo que até aqui o tem cumulado de benefícios sem conta, de bênçãos sem número! Se cada católico paulista der por Cristo Jesus a luz de sua inteligência e o amor de seu coração o Congresso será deslumbrante em esplendor, edificante em piedade! O setor onde o professorado católico deve agir já está determinado: é entre os colegas arrastando-os com o exemplo de uma atividade piedosa; é entre as crianças aproximando-as desde já de Jesus pelo preparo conveniente, pelas comunhões mais freqüentes, pela participação nas 'semanas eucarísticas'. À frente desse setor está o Diretor do Ensino religioso, coadjuvando pelo Revmo PE Veiga Jesuíta. O Revdmo Pe. Veiga será o orientador das transmissões radiofônicas dos estabelecimentos de ensino e deve ser procurado com urgência pelas delegadas ou pessoas interessadas em participar do programa. Adiantar S. revdma que o G.E. Amadeu Amaral será representado pelo próprio diretor no dia que lhe for destinado. Para tudo mais no referido setor como Diretor do Ensino Religioso, coloca-se à disposição dos professores sempre pronto a atendê-los, a orientá-los e a ajudá-los a remover dificuldades. Participou que já convidou para 
membro da Comissão de honra a Exma Sa D. Anita Costa, D. D. Esposa do Sr. Interventor Federal. O convite foi aceito com manifestação de agrado e outros mais serão feitos a senhoras de destaque social ligadas pór laços de parentesco aos elementos oficiais e às autoridades escolares. A comissão de honra é de muita necessidade e de grande alcance, e que ninguém ignora, disse, o Revdmo Diretor e, acrescenta logo a seguir o que ninguém pode ignorar também, é que cada professor católico é membro ativo da comissão efetiva do Congresso. Diz que, entre o professorado católico, reserva para si o papel de juiz para julgar as sugestões apresentadas e escolher as mais úteis no momento, ou então, o de General a dirigir professores, verdadeiros soldados de Cristo que, com Jesus no coração buscam outros corações em santa e abençoada campanha para o triunfo e glorificação do Filho de Deus. - o Rei dos Reis! Pede aos professores que sintonizem seus aparelhos nos dias reservados à propaganda do Congresso, pois de agora em diante passará a transmitir ordem e ordenações pelo rádio. Avisa que a próxima reunião será na Cúria Metropolitana, às 10h 30 do dia 26 de abril e deve ser precedida de grande propaganda entre os professores.

\section{Coleta em favor do Ensino Religioso}

De ordem do exmo. Sr. Arcebispo Metropolitano hoje, será feita em todas as paróquias, igrejas e capelas deste arcebispado uma coleta que reverterá em benefício do ensino religioso.

É tradição nesta arquidiocese reservar-se os generosos donativos dos fiéis para esse domingo, que são utilizados para incremento do ensino da doutrina cristã.

Tantos e tão grandes são os problemas religiosos em nossa querida pátria, mas este, o do ensino da doutrina cristã às crianças, é dos de maior importância e para sua solução devem concorrer todos os fieis, quer ministrando essa doutrina nas igrejas, nas escolas e nos lares, quer indiretamente auxiliando as obras de 
propaganda religiosa, sendo este um dos meios para facilmente cumprir-se o quinto mandamento da Santa Igreja: pagar os dízimos segundo o costume.

Conhecendo de perto as urgentíssimas e as tão grandes dificuldades, quero deixar aqui neste aviso um apelo encarecido a todos os fieis, mas de uma maneira mui especial aos caríssimos pais de família e aos tão zelosos professores que têm oportunidade de apalpar dia a dia essas mesmas necessidades, para que se unam todos em fervorosa prece e auxiliem na medida de suas posses tão meritória obra de patriotismo.

Deus Nosso Senhor recompensará cem por um todo sacrifício feito com tão reta intenção.

\section{Congresso Eucarístico de 1942}

Grupo Escolar Reinaldo Ribeiro da Silva na Vila Anastácio - Lapa

Número de alunos que compareceram ao Congresso Eucarístico de 1942: 350

Número de alunos que comungaram no dia 5 de setembro: 350

Contribuição do Estabelecimento para o Congresso: 175\$000

Bandeirinhas adquiridas pelos alunos: 250 (250\$000)

Ramalhete espiritual

Missas -4.656

Comunhões -2.500

Dezenas - 24.750 De 14/5 - Ascensão a 15/8 - Assunção 
Jaculatórias -480.983

Visitas ao SS -15.650

Sacrifícios -20.960

Observação: Grande e belíssima foi a participação dos alunos do estabelecimento ao Congresso Eucarístico Nacional de 1942. Trezentos e cinqüenta alunos dos 607 matriculados, compareceram à reunião magna de 5 de setembro e receberam a Sagrada Comunhão. Foi de 57,60 a porcentagem de comparecimento. Nos meses que antecederam o Congresso, já se fazia sentir no nosso grupo um movimento religioso extraordinário, como pode atestar o Ramilhete espiritual. Tudo isto, no entanto, devemos à boa e excelente diretora ou melhor Delegada do Ensino Religioso no estabelecimento Prof. D. Gilda de Barros Silveira, que n'um devotamento sem par, tudo fez, tudo acertou, tudo organizou, para que nada faltasse para 0 esplendor desse notável e sempre lembrado $4^{0}$ Congresso Eucarístico. A ela, mais que tudo e, ao devotadíssimo Padre Osvaldo Szeler, nosso queridíssimo Pároco, os nossos melhores aplausos.

\section{Entronização de Crucifixo}

Grupo Escolar Osvaldo Cruz - Mooca

Ata da solene entronização da Sagrada Imagem de Jesus Crucificado

Aos três dias do mês de dezembro do ano de Nosso Senhor Jesus Cristo de mil novecentos e quarenta e quatro, às dez horas, no Grupo Escolar Osvaldo Cruz, com a presença das altas autoridades eclesiásticas, civis, professores do estabelecimento e pessoas convidadas, teve lugar a solene entronização da Sagrada Imagem de Jesus Crucificado. A cerimônia que se revestiu de grande brilho contou, também, com a presença das irmandades da Paróquia de São 
Rafael e dos moradores do bairro da Mooca. Foi desenvolvido o seguinte programa: às nove horas houve missa na Paróquia de São Rafael e, em seguida, em procissão solene, a Sagrada Imagem foi conduzida para este Grupo Escolar onde teve lugar a cerimônia da bençam e entronização. Usaram da palavra o Exmo. Revmo. Padre Manoel Pereira de Almeida, D.D. Diretor de Ensino Religioso e representante do Exmo. Revmo. Sr. Arcebispo Metropolitano; o Exmo. Revmo. Sr. padre Savino Aggazzi, D.D. Vigário da Paróquia de São Rafael; o Sr. Prof. João Pereira, diretor do G.E. Osvaldo Cruz que também leu a oração sendo acompanhado por todos os presentes. Após a cerimônia, todos os presentes desfilaram perante a Sagrada Imagem. De tudo, para constar, eu, João Pereira, datilografei a presente ata que depois de lida vai assinada pelas autoridades eclesiásticas, civis, professores do estabelecimento presente à solenidade e por mim. Nomes dos presentes.

Grupo Escolar Marechal Bittencourt

Entronização da Imagem de Jesus Crucificado

"No dia 22 de outubro ? findo, na sala da diretoria do Grupo Escolar "Marechal Bittencourt" de Osasco ${ }^{106}$, realizou-se a solene cerimônia de entronização do Crucifixo.

Às oito horas e meia foi iniciada a missa no pátio do estabelecimento. A seguir, em procissão, os alunos conduziram a imagem de Jesus Crucificado por algumas ruas da localidade, antes de levá-la ao local da entronização. Depois, no portão principal do educandário, foi dada a benção à imagem, a qual, em seguida, veio a ser entronizada pelo diretor do estabelecimento.

Estes atos decorreram com a imponência que os caracteriza e aos mesmos compareceram as autoridades escolares e eclesiásticas, as professoras

\footnotetext{
${ }^{106}$ Osasco fez parte do município de São Paulo até 1962, quando foi realizado um plebiscito, tornando o município autônomo.
} 
e alunos dos educandários de Osasco e o povo em geral." (Osasco, 29 de novembro de 1944) $)^{107}$

Em um texto encontrado nos arquivos do Arcebispo D. José Gaspar, foi encontrado um texto comemorativo da entronização do Crucifixo no Grupo Escolar da Fábrica de Piquete, de 16 de maio de 1942. Não há menção do autor do documento, mas pela leitura, é provável que tenha sido redigido pela diretora do estabelecimento. $O$ evento ocorrido no município, contou com a presença do Arcebispo, bispos, autoridades militares e civis. O relato diz:

Impulsionada por uma força estranha, que me faz vir audaciosa, portanto, dirigir-vos algumas palavras, o faço com indizível satisfação, não sendo, por conseguinte minhas expressões buriladas pelo cinzel da forma, porém legitimamente nascidas do coração que as transporta aos lábios, para exprimir o quanto de grandioso se passa neste recinto.

Como uma batalhadora que vê seu ideal [...] vitorioso, assim me considero na contemplação deste quadro sublime de Fé e amor para Aquele que foi, é e será o Deus de amor e bondade.

Piquete, este recanto paulista, situado ao sopé da majestosa Mantiqueira, se eleva hoje católica e enaltecidíssima, por ter em seu seio Hóspedes de tão alta dignidade; e marque em nossos corações de cristãos e aos seus filhos, uma inolvidável e gravíssima lembrança de momentos de tão justo encantamento.

Demos graças ao Senhor por esta especial concessão de Vossas Augustíssimas passagem entre nós.

O meu coração de mestra pulsa hoje com mais ardor, ante a grandeza deste momento e como a nau, que partindo do seu porto, singra o mar por vezes bonançoso, por vezes encapelado, no cumprimento de seu sagrado dever, assim, me vedes aqui, pois deixando o Lar, onde afetos íntimos me acorrentam, e no entanto, assim distante, encontra o conforto moral no desempenho da missão espinhosa que Deus me determinou - a de educadora - e se às vezes, no desempenho desse mister, um abatimento quer me esmorecer, ah então volvo o pensamento para o Divino Mestre e Ali, pouco a pouco o reconforto torna e eis-me a prosseguir na procela...

${ }^{107}$ Arquivo da Cúria Metropolitana. Livro 59-01-069 Grupo Escolar Marechal Bittencourt - Osasco 
Assim, a entronização do Cristo em nosso Grupo Escolar, é a graça Suprema que vem exemplar-nos e dignificar-nos em nossas atitudes - A escola é irmã da religião - O que será do mundo se ambas não formarem um elo complementar uma da outra? Introduzindo-se a religião na escola, será um vigoroso escudo às investidas do materialismo destruidor. A ciência e a religião são dois poderosos faróis da humanidade - esta, acalenta, reedifica, constrói a alma; a 1ii ilumina o cérebro. Um corpo sem alma?

Oh! Nada mais seria que um montão de massa complexa, indiferente aos sentimentos, que para aquela é tudo!

O que valeriam as admiráveis descobertas das ciências, se não houvesse como base disso tudo, um sinal evidente de fé sublime, uma convicção persistente baseada nos princípios humanos, cuja origem é Deus e cujo final vitorioso converge para Deus!

Tudo se vence, amando-O sobre todas as coisas, isto é adorando ao Nosso Senhor e nosso Deus e amando ao nosso próximo como a nós mesmos...

E, entronizando ao Senhor Crucificado em nosso Grupo Escolar, convictos ficamos, Oh! Meu Divino Mestre, que nos dareis forças, alegria, luzes inspiradoras de inteligência e fecundas, tudo isso unificado no Bem que és Tu, para o bem que de Ti vem e nesta tenda de trabalho com os pequeninos, digamos:

Cristo reina!

Cristo impera!

Cristo vence!

E a Vós, oferecemos a flor d'alma - a nossa eterna gratidão, solicitando Vossas bênçãos sobre comandantes e comandados."

Segue-se o hino cantado pelo Grupo Escolar:

“Tu reinarás, é nosso brado!

Brado de Fé e de louvor.

Tu reinarás, tu reinarás

Oh! Cristo Rei-Nosso Senhor!

Nossa delícia, então consiste

Em te servir, com todo ardor,

Sempre exaltando a Tua glória 
Oh! Jesus Cristo-rei do Amor!"108

${ }^{108}$ ARQUIVO DA CÚRIA METROPOLITANA. Pasta CBA: 06-03-05. Discurso em ocasião da entronização do Crucifixo no Grupo Escolar da Fábrica de Piquete. 16.05.1942 
Capítulo 4

Fiscalização do Ensino Religioso 
Os Relatórios da Inspetoria Arquidiocesana nas escolas formam um conjunto documental bastante interessante. Estão disponíveis, no Arquivo da Cúria Metropolitana de São Paulo, relatórios de 51 Grupos Escolares, sendo que 38 são do período de estudo em questão (1930 a 1945). Todos são dos anos 40 em diante; a maioria começa no ano de 1941, quando teve início a atividade da Inspetoria. Boa parte dos relatórios analisados leva a assinatura do Pe. João Pheeney de Camargo e Silva, Diretor Arquidiocesano do Ensino Religioso, ou de alguma Delegada do Ensino Religioso. 109

Todos os anos, as autoridades visitavam as escolas públicas da capital e também de cidades vizinhas, como São Bernardo do Campo, São Caetano do Sul e Poá. Realizava-se um inquérito que, muitas vezes, o próprio diretor da escola respondia e assinava. As perguntas feitas variavam muito pouco. Nome do estabelecimento, localização, paróquia à qual pertencia a escola, nome do pároco, períodos de funcionamento da escola e número de classes.

O questionário prosseguia determinando os nomes: das professoras católicas e não católicas que lecionavam Religião; das professoras católicas que não lecionavam a disciplina; nomes das professoras protestantes, espíritas e ateias. As professoras que ensinassem religião deviam ter uma Ficha de Identidade na Diretoria Arquidiocesana. ${ }^{110}$ Seguiam-se: o número de alunos matriculados; quantidade de alunos católicos, protestantes, espíritas, israelitas e sem religião definida. Os relatórios também interrogavam o número de alunos que fizeram a celebração da Páscoa e que se preparavam e que haviam realizado a Primeira Comunhão.

Nas partes finais, o interrogatório indagava se as escolas possuíam crucifixo entronizado e se havia material para a catequese. As perguntas mais instigantes eram sobre atritos no estabelecimento por causa do Ensino Religioso, se houve batizados ou conversões e quantos catecismos do Pe. Quinet a escola possuía ou adquirira.

\footnotetext{
109 A partir de 11.09.1941, os Relatórios da Diretoria Arquidiocesana do Ensino Religioso passaram a ser publicados no jornal Correio Paulistano, em resposta a um articulista que acusou a Igreja de não aproveitar em nada os decretos autorizando o ensino religioso nas escolas.

${ }^{110}$ No Arquivo da Cúria Metropolitana, foi encontrada uma relação com 3.940 nomes de professores de Ensino Religioso registrados nas Diretorias Regionais de Ensino da Capital e outros municípios. Os nomes estavam em papéis timbrados da Diretoria Arquidiocesana do Ensino Religioso, carimbados e assinados pelo Pe. Pheeney. Os nomes correspondiam às fichas dos docentes, que não foram encontradas.
} 
Os dados sobre conversões despertam grande curiosidade para a pesquisa. Nos relatórios observados, poucos alunos foram convertidos ao catolicismo. Porém, é necessário pensar na possibilidade das conversões terem sido forçadas.

Maria Luiza Tucci Carneiro analisa o antissemitismo na Era Vargas. "Existiram entre nós, o paraíso dos trópicos, condimentos necessários que quase nos transformaram num purgatório nazista." "E no caminho das ideias nacionalistas, o judeu emergia como personagem indesejável, ao lado do negro e do japonês. Com a instauração do regime autoritário estadonovista, o antissemitismo encontrou campo propício à sua eclosão." O sentimento não foi gestado nas entranhas do Estado Novo, mas acompanhando a trajetória de vida dos intelectuais que atuaram em fins do século XIX e nas primeiras décadas do século $X X$, verificaremos, ao nível da história das ideias, que muitos que se integraram no projeto político-cultural do Estado Novo, ou então tiveram suas obras reeditadas e suas ideias assimiladas.

A formulação de uma política imigratória na época era questão de segurança nacional. A imagem do judeu junto à opinião pública alimentava o sentimento antissemita. As hipóteses da autora para o negativismo em relação aos judeus são: instrumento de poder, luta de classes, influência da Igreja, quanto a crenças em conflito.

"Constatamos, ainda, que as fontes primárias consultadas, apesar de expressarem uma realidade complexa, mantêm certa homogeneidade quanto ao seu conteúdo antissemita. As acusações se repetem, tornando-se, muitas vezes, cansativas e redundantes, atribuindo, arbitrariamente, traços de inferioridade ao judeu."

Apesar das estatísticas das conversões e alguns depoimentos sobre 0 assunto, em nenhum documento da Igreja ou artigos nos jornais aparece algum discurso antissemita. As conversões podem ser parte da própria Igreja em querer reunir todos no cristianismo.

Em 1939, para Tucci Carneiro, houve apelo de Pio XII pela imigração de 3.000 judeus para o Brasil. A condição era: a conversão ao catolicismo. "Apesar de que, não chegou a aflorar a prática do criptojudaísmo, visto que não houve perseguição sistemática àqueles que praticavam o judaísmo." $\mathrm{O}$ antissemitismo 
que se manifestou durante o Estado Novo foi, antes de tudo, político. Qualquer medida legal tomada contra os judeus foi de forma camuflada. ${ }^{111}$

\section{Figura 3: Questionário da Diretoria Arquidiocesana do Ensino}

\section{Religioso nas escolas}

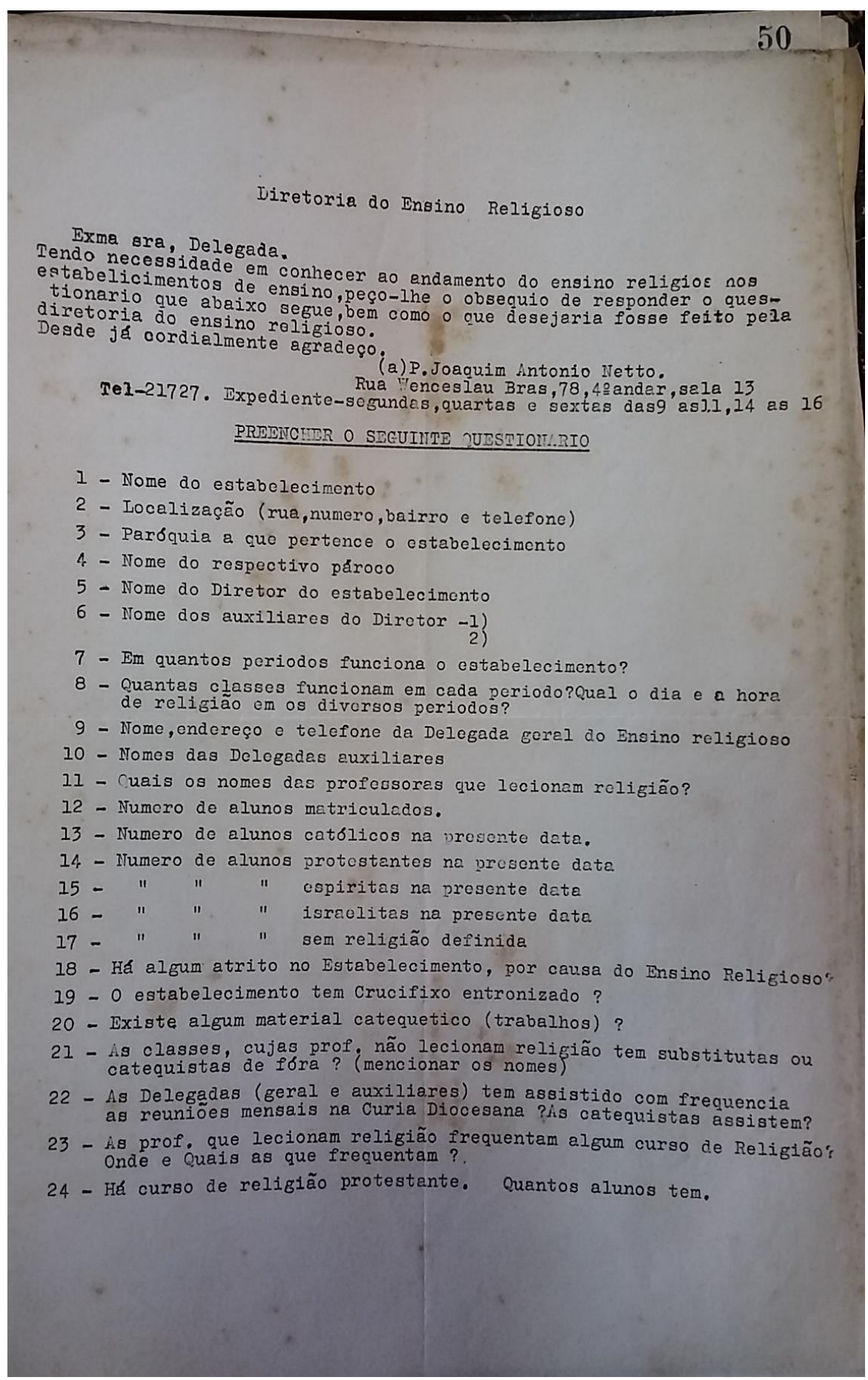

Fonte: Arquivo da Cúria Metropolitana

${ }^{111}$ CARNEIRO, Maria Luiza Tucci. O antissemitismo na Era Vargas: fantasmas de uma geração 1930-1945. São Paulo: Brasiliense, 1988. pp. 22-27 / 234-247. 
Domingo último, na Cúria Metropolitana, sob a presidência do diretor e inspetor arquidiocesano do Ensino Religioso, realizou-se a reunião mensal das delegadas, professoras e catequistas. Após a abertura da sessão, o revmo. Padre João Pheeney C. e Silva, fez a apresentação às presentes do revmo. padre Paulo Arisol C. Freire, recentemente nomeado para o cargo de inspetor arquidiocesano do Ensino Religoso.

Foram a seguir expostas as diversas providências que a Inspetoria acaba de adotar, para a boa ordem e melhor eficiência do Ensino Religioso em nossas escolas públicas e particulares. Essas providências, em resumo, são as seguintes:

1) Obrigatoriedade da adoção do catecismo do padre Quinet nas aulas de Religião, em toda a Província Eclesiástica de S. Paulo, como determina a Pastoral Coletiva do episcopado paulista.

2) Organização de um programa de exames, para os alunos de religião, programa este em vias de acabamento e que será largamente distribuído entre os professores de religião.

3) Necessidade de passar trabalhos aos pequenos, para que os façam em suas casas.

4) Necessidade da impressão de quadros morais.

5) a) As orações até 7 de setembro, serão pelas missões atualmente realizadas na arquidiocese; b) obrigatoriedade da abstinência de carne nas sextas-feiras da Quaresma; c) comunhão mensal que os professores devem promover entre os alunos e d) a questão das comunhões pascoais, que deverão ser sempre combinadas previamente, pela delegacia, com o diretor do grupo e o pároco.

Após essas determinações, usou da palavra o revmo. padre Aurisol Freire, que expôs, entre outros pontos os seguintes:

1) Necessidade da apresentação de um relatório mensal sobre o movimento religioso, segundo desejo expresso do Sr. arcebispo

2) Publicação de duas circulares, a respeito do ensino religioso, expedidas pelo diretor geral do Departamento de Educação. 
3) Pedidos de fichas, os quais devem ser claros e para as professoras novas, fichas de $1^{\text {a }}$ via para as que já receberam e perderam, fichas de $2^{\underline{a}}$ via.

4) Necessidade do resumo mensal, coisa indispensável para o arquivo do ensino religioso, para que se possa a qualquer momento, fornecer um relatóriio sobre o andamento do mesmo, não raras vezes solicitado pelas autoridades. O referido Resumo Mensal poderia ser distribuído juntamente com o resumo mensal do diretor do grupo, por ele próprio, sempre que a isto não se opusesse, facilitando assim o controle. Os resumos, uma vez prontos, deverão ser remetidos com urgência à Diretoria Arquidiocesana do Ensino Religioso.

5) Pedido às delegadas, para que tudo façam com extrema prudência, visando sempre evitar todo e qualquer atrito com os diretores dos grupos e não venham destarte a criar casos insolúveis dentro do estabelecimento, apenas prejudicando, e grandemente, o ensino da religião.

Esgotada a matéria do dia, foi encerrada a reunião com as orações costumeiras, ficando assentado ainda que, doravante as reuniões ficam fixamente marcadas para o último domingo de cada mês. ${ }^{112}$

No relatório do Grupo Escolar "Oscar Thompson", do Cambuci, do ano de 1942, a resposta à questão dos batismos e conversões foi a seguinte: "Houve o batizado do aluno Luiz Corneta, do $3^{0}$ ano B masculino. Houve a conversão do aluno israelita Pedro Piorkovski, do 3ำ ano $\mathrm{C}$ masculino. Seu batizado realizou-se na Igreja de Nossa Senhora da Glória (Paróquia de São Joaquim) tendo sido assistido por todos os colegas de classe a que pertence o convertido. Foi o desejo de participar da Grande Comunhão Infantil do Congresso que levou esse menino de 12 anos de idade à conversão. O pequeno Pedro participou dessa Comunhão com viva emoção dizendo a todos que jamais veria coisa tão linda em sua vida. Entrou para a Cruzada Eucarística da Igreja onde se batizou."113

\footnotetext{
112 O Estado de S. Paulo. 05.03.1941_pág. 2

113 ARQUIVO DA CÚRIA METROPOLITANA. Inspetoria Arquidiocesana nas escolas (Relatórios). Grupo Escolar Oscar Thompson - Cambuci. Livro: 59-01-049 (1941-1957). Relatório de 1942 assinado pelo Pe. Pheeney.
} 
No relatório de 1941, aparece uma resposta ao questionamento sobre o Crucifixo: "o estabelecimento possui crucifixo entronizado desde o dia 16 de Novembro de 1940. A entronização foi solenemente feita por S. Exma. Revma. D. José Gaspar de Afonseca e Silva, Arcebispo Metropolitano, estando presentes representantes do Governo do Estado." ${ }^{114}$ Nota-se a íntima relação entre os poderes eclesiásticos e a educação.

A diretora Laura Prestes Barra do Grupo Escolar São José, no bairro do Ipiranga, respondeu, ela mesma, ao questionário da Inspetoria, em 1941. Segundo ela, todas as professoras da instituição eram católicas, pois isso era condição essencial para que fossem admitidas no quadro do corpo docente. $O$ ensino religioso fora feito por todas as professoras, cada uma em sua classe. Porém, a partir de 1936, ele ficou a cargo de "professoras bem piedosas que se dedicavam exclusivamente a isso". Para as classes do $1^{\circ}$ ano eram dadas duas aulas semanais de 30 minutos e para os $2^{\circ} \mathrm{s}$, $3^{\circ} \mathrm{s}$ e $4^{\circ} \mathrm{s}$ anos, uma aula semanal de 50 minutos. Aos sábados, os alunos que já tivessem feito a primeira Comunhão eram acompanhados à Igreja do Juvenato do S.S. Sacramento, onde os Padres Salesianos os atendiam no Confessionário. O grupo era dividido em duas partes para as confissões: num sábado iam 13 classes e no outro sábado, as outras 13 , de modo que as crianças se confessavam a cada 15 dias. ${ }^{115}$

A escola, naquela data, contava com 1044 alunos freqüentes. Havia 995 alunos católicos. A diretora abriu um parêntesis, dizendo: "se fossemos, porém, verificar a religião das famílias desses alunos encontraríamos, estou certa, um número muito grande de espíritas, protestantes e indiferentes." ${ }^{116} \mathrm{O}$ estabelecimento possuía, segundo Laura Prestes Barra, crucifixo em todas as salas de aula e as crianças rezavam na hora da entrada e da saída, antes e depois do recreio.

No ano seguinte, 1942, respondendo à questão dos batismos e conversões, a diretora do Grupo São José escreveu que existiam três alunos não batizados. Desses três, dois eram irmãos e tinham um espírito religioso muito

\footnotetext{
${ }^{114}$ ARQUIVO DA CÚRIA METROPOLITANA. Inspetoria Arquidiocesana nas escolas (Relatórios). Grupo Escolar Oscar Thompson - Cambuci. Livro: 59-01-049 (1941-1957). Relatório de 1941 assinado pelo Pe. Pheeney.

115 ARQUIVO DA CÚRIA METROPOLITANA. Inspetoria Arquidiocesana nas escolas (Relatórios). Grupo Escolar São José - Ipiranga. Livro: 59-01-043. Relatório de 1941.

${ }^{116}$ Ibid.
} 
marcado. Assistiam missa, rezavam piedosamente o terço, etc. Contavam, porém, com a oposição violenta do pai, que se dizia ateu. ${ }^{117}$

No Grupo Escolar Godofredo Furtado (atual Escola Estadual Godofredo Furtado), localizada em Cerqueira César, existiam, em 1944, 1978 alunos, dos quais 1850 eram católicos, 52 protestantes, 26 israelitas, 38 espíritas e 12 sem religião definida. O Inquérito aponta que havia um padre responsável pelo ensino religioso ali, o Revmo. Padre Rafael. Ele reunia, de acordo com o documento, diversas classes, ora para aulas propriamente ditas, ora para exibição de filmes bíblicos, com excelentes resultados. Em $1^{\circ}$ de Outubro daquele ano, o Revmo. Padre Manuel esteve no local para entronização do crucifixo, ocasião precedida de uma procissão em que os alunos saíram da Matriz para o Grupo, onde foi celebrada uma missa campal pelo Cônego Antonio de Castro Mayer. ${ }^{118}$

Uma inovação foi introduzida nas aulas, conforme os dizeres do relatório. Cada classe passou a ter uma igrejinha de cartolina onde todas as segundasfeiras eram colocados em posição vertical, as bandeirinhas com o nome dos alunos que assistiram missa no domingo e em posição horizontal aquelas cujos donos não foram à missa. Houve diversos batizados e alguns alunos, de diferentes religiões resolveram, com o assentimento dos pais, assistir às aulas de religião católica. Concluindo, o relato daquele ano, o Grupo era representado sempre nas reuniões da Diretoria do Ensino Religioso, muitas professoras tinham curso regular de religião dos colégios em que estudaram. O estabelecimento havia adquirido muitos catecismos do Padre Quinet, por intermédio do Padre Rafael, que fornecia também instruções orais e livros de religião para cultura dos professores e prêmios para os melhores alunos. ${ }^{119}$

No Inquérito do mesmo Grupo Escolar do ano seguinte, 1945, a Delegada do Ensino Religioso, Assunta Orsini, voltou a mencionar a atividade do Padre Rafael, reiterando a instrução religiosa de diversas classes por meio de filmes e cantos religiosos, com visível aproveitamento. Para a cultura dos professores, o padre dava instruções orais e livros de religião a estes e prêmios de encorajamento aos alunos como, por exemplo: medalha à classe que

\footnotetext{
${ }^{117}$ ARQUIVO DA CÚRIA METROPOLITANA. Inspetoria Arquidiocesana nas escolas (Relatórios). Grupo Escolar São José - Ipiranga. Livro: 59-01-043. Relatório de 1942.

${ }^{118}$ ARQUIVO DA CÚRIA METROPOLITANA. Inspetoria Arquidiocesana nas escolas (Relatórios). Grupo Escolar Godofredo Furtado - Cerqueira César. Livro: 59-01-061. Relatório de 1944. ${ }^{119}$ Ibid.
} 
apresentasse maior número de alunos à missa das crianças na Paróquia. $\mathrm{O}$ documento ainda relatou 3 conversões e 2 batizados de alunos. ${ }^{120}$

\section{Grupo Escolar São José do Ipiranga}

\section{Relatório da diretora Laura Prestes Barra em 1950 (fora do período)}

"Os alunos fazem orações em comum: no páteo do recreio (antes da entrada das aulas) e nas classes, com as professoras.

Orações que são feitas no páteo: oferecimento do dia do "Apostolado da Oração", Consagração a Nossa Senhora, Ato de Contrição e orações jaculatórias. Em geral, cantam também aí um hino religioso. Nas classes rezam: Padre-Nosso, Ave-Maria, Credo ou Salve Rainha.

Aos domingos e dias santificados são celebradas duas S. missas para assistência dos alunos: uma, na Capela do Instituto Padre Chico, para as alunas (que são acompanhadas por Irmãs Salesianas); e outra, na Capela do próprio Grupo (instalada no $3^{\circ}$ andar), para os meninos, que são acompanhados pela delegada geral, que esta subscreve.

Trabalho difícil é conseguir que os alunos assistam missa. Não estão acostumados a isso. Os pais, em regra geral, não assistem e acham que os filhos não precisam assistir. Alegam que trabalham a semana toda e que aos domingos precisam descansar mais, que saem para passeio fora de S. Paulo, que moram longe, etc. etc. No entanto, alguma coisa se consegue (uma média de comparecimento de uns 700-800 alunos) ${ }^{121}$, sendo que há mesmo crianças que atravessam o ano sem perder nenhuma (Deus seja louvado). É trabalho das delegadas todos os sábados e vésperas de dias santos avizar (sic) aos alunos da obrigação de assistência à Missa no dia seguinte. Aos domingos, os alunos recebem um cartãozinho com a data carimbada e devem entregá-lo na $2^{a}$ feira para a professora que registra o comparecimento numa lista apropriada."

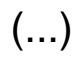

\footnotetext{
${ }^{120}$ ARQUIVO DA CÚRIA METROPOLITANA. Inspetoria Arquidiocesana nas escolas (Relatórios). Grupo Escolar Godofredo Furtado - Cerqueira César. Livro: 59-01-061. Relatório de 1945.

${ }^{121}$ O Grupo Escolar tinha 1.121 alunos, de acordo com o relatório de 1950, 1.070 "que se dizem católicos" enfatiza a diretora, 40 protestantes, 8 espíritas e 2 israelitas.
} 
"Atendendo ao pedido de me manifestar sobre o que desejaria que fosse feito pela diretoria do Ensino Religioso, diria o seguinte: que ela promovesse (uma vez em cada semestre, vamos dizer), no próprio estabelecimento, uma exortação às professoras, que poderia ser feita pelas missionárias de Jesus Crucificado, chamando o corpo docente à compreensão da sua elevada missão educadora. Muito mais se poderia conseguir se as professoras tivessem todas, uma consciência católica bem formada. As reuniões na Cúria parecem muito úteis e necessárias, mas se referem às delegadas. Seria necessário, parece-me, que as professoras recebessem uma palavra, de quando em quando."

Grupo Escolar Vila Prudente 1944

"Por motivo de força maior, estive licenciada durante o ano todo não podendo dar as informações acima mencionadas." Elvira Marques Passalacqua

Peço a Deus Nosso Senhor uma benção especial para este Grupo...

São Paulo, 2 de março de 1945.

Pe. Manoel Pereira de Almeida

Nos relatórios do Grupo Escolar de 1942 e 1943, as informações sobre alunos e professoras de outras religiões não foram colhidas porque o Sr. Diretor Umberto Conte Checcia não permitiu que a delegada do Ensino Religioso colhesse essas informações. Daí o comentário e pedido especial do padre, Diretor do Ensino Religioso. 
Estatísticas dos Grupos Escolares encontrados no Arquivo da Cúria Metropolitana em relação ao questionário da Inspetoria Arquidiocesana do Ensino Religioso

Legenda:

Matr. - Número de alunos matriculados no início do ano

Freq. - Número de alunos freqüentes no final do ano durante a inspeção

Cat. - Número de alunos católicos

Prot. - Número de alunos protestantes

Esp. - Número de alunos espíritas

Isr. - Número de alunos israelitas

$\mathrm{S} / \mathrm{R}$ - Alunos sem religião definida

Páscoa - Alunos que fizeram a Páscoa naquele ano

$11^{\text {a }} \mathrm{COM}$ - Alunos que fizeram a Primeira Comunhão

P. $1^{\text {a }} \mathrm{COM}-$ Alunos que se preparavam para a Primeira Comunhão 
GRUPOS ESCOLARES VISITADOS PELA INSPETORIA ARQUIDIOCESANA DO ENSINO RELIGIOSO DA ARQUIDIOCESE DE S.PAULO

\begin{tabular}{|c|c|c|c|c|c|c|c|c|c|c|c|}
\hline & 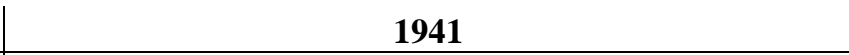 & MATR. & FREQ. & CAT. & PROT. & ESP. & ISR. & S/ R. & PASCOA & $1^{\text {a }}$ COM. & P. $1^{\text {a }}$ C. \\
\hline 1 & ARMANDO ARAÚJO - MOÓCA & 1.157 & 1.138 & 1.099 & 25 & 13 & - & 1 & 404 & 404 & 190 \\
\hline 2 & ARMANDO BAYEUX - CAMBUCI & 992 & 958 & 909 & 22 & 13 & - & 14 & 272 & 375 & 180 \\
\hline 3 & BAIRRO DO LIMÃO & 529 & 520 & 469 & 22 & 15 & - & 13 & 91 & 32 & 40 \\
\hline 4 & BARTOLOMEU BUENO DA SILVA - S. C. SUL & 1.083 & 964 & 1.018 & 43 & 6 & 3 & 10 & 224 & 359 & 158 \\
\hline 5 & BENEDITO TOLOSA - CASA VERDE & 581 & 612 & 548 & 39 & 21 & - & 4 & 152 & 172 & 110 \\
\hline 6 & GAL. COUTO DE MAGALHÃES - JD. AMÉRICA & 598 & - & 562 & 19 & 4 & 12 & - & 156 & 213 & 131 \\
\hline 7 & GODOFREDO FURTADO - JD. AMÉRICA & 1.480 & 1.328 & 1.210 & 72 & 26 & 10 & 2 & 311 & 294 & 181 \\
\hline 8 & GOMES CARDIM - JD. DA GLÓRIA & 560 & 600 & 562 & 30 & 7 & 1 & - & - & 68 & 74 \\
\hline 9 & IBIRAPUERA - BROOKLIN PAULISTA & 405 & 389 & 361 & 11 & 9 & 1 & 7 & 68 & 100 & 52 \\
\hline 10 & JOAO VIEIRA DE ALMEIDA - VILA MARIA & 1.245 & 1.245 & 1.140 & 73 & 20 & 1 & 1 & 220 & 99 & - \\
\hline 11 & JOSÉ ESCOBAR - IPIRANGA & 680 & 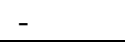 & 641 & 23 & 6 & - & - & 184 & 274 & - \\
\hline 12 & JÚLIO RIBEIRO - BELA VISTA & 1.169 & 1.102 & 1.046 & 31 & 20 & 1 & 1 & 376 & 92 & 586 \\
\hline 13 & MANOEL DA NÓBREGA - FREGUESIA DO Ó & 838 & 767 & 772 & 51 & 7 & 1 & 7 & 250 & - & 120 \\
\hline 14 & MARECHAL FLORIANO - VILA MARIANA & 2.558 & 2.484 & 2.316 & 110 & 36 & 2 & 20 & 731 & 805 & 387 \\
\hline 15 & MARTIM FRANCISCO - VILA OLÍMPIA & 327 & 319 & 294 & 22 & 3 & - & - & 130 & 153 & 74 \\
\hline 16 & OSCAR THOMPSON - CAMBUCI & 1.263 & 1.257 & 1.206 & 26 & 13 & 1 & 11 & 245 & - & 193 \\
\hline 17 & OSVALDO CRUZ - MOÓCA & 2.401 & 2.386 & 2.283 & 61 & 34 & - & 23 & 758 & 914 & 1.353 \\
\hline 18 & PANDIÁ CALÓGERAS - PARQUE DA MOÓCA & 350 & 316 & 310 & 2 & 2 & - & 2 & 84 & - & 35 \\
\hline 19 & PAULO EIRÓ - SANTO AMARO & 1.020 & 948 & 854 & 64 & 19 & 10 & 1 & 369 & 527 & 50 \\
\hline 20 & PEREIRA BARRETO - LAPA & 2.430 & 2.362 & 2.280 & 98 & 18 & 10 & 24 & 440 & - & 300 \\
\hline 21 & PRINCESA ISABEL - SAÚDE & 1.145 & 1.140 & 1.076 & 46 & 7 & - & 11 & 324 & 414 & 80 \\
\hline 22 & REINALDO RIBEIRO DA SILVA - VILA ANASTÁCIO & 655 & 600 & 498 & 37 & 10 & 1 & 7 & 240 & - & 126 \\
\hline 23 & ROCA DORDAL - BRÁS & 1.170 & 1.098 & 1.026 & 37 & 28 & 6 & 1 & 255 & 198 & 200 \\
\hline 24 & SÃO JOSÉ - IPIRANGA & 1.065 & 1.044 & 995 & 19 & 7 & - & 3 & 719 & 1 & 271 \\
\hline 25 & THOMAS GALHARDO - ÁGUA BRANCA & 844 & 826 & 789 & 24 & 7 & 1 & 5 & 334 & 350 & 167 \\
\hline 26 & VILA ESPERANÇA & 732 & 729 & 665 & 27 & 24 & 7 & 9 & 213 & 56 & 159 \\
\hline 27 & VILA LEOPOLDINA & 280 & 267 & 248 & 13 & 6 & - & - & 63 & 120 & 30 \\
\hline 28 & VILA PEDRO I & 738 & 681 & 627 & 39 & 14 & - & 1 & 331 & 59 & 31 \\
\hline & TOTAL & 28.295 & 26.080 & 25.804 & 1.086 & 395 & 68 & 178 & 7.944 & 6.079 & 5.278 \\
\hline
\end{tabular}




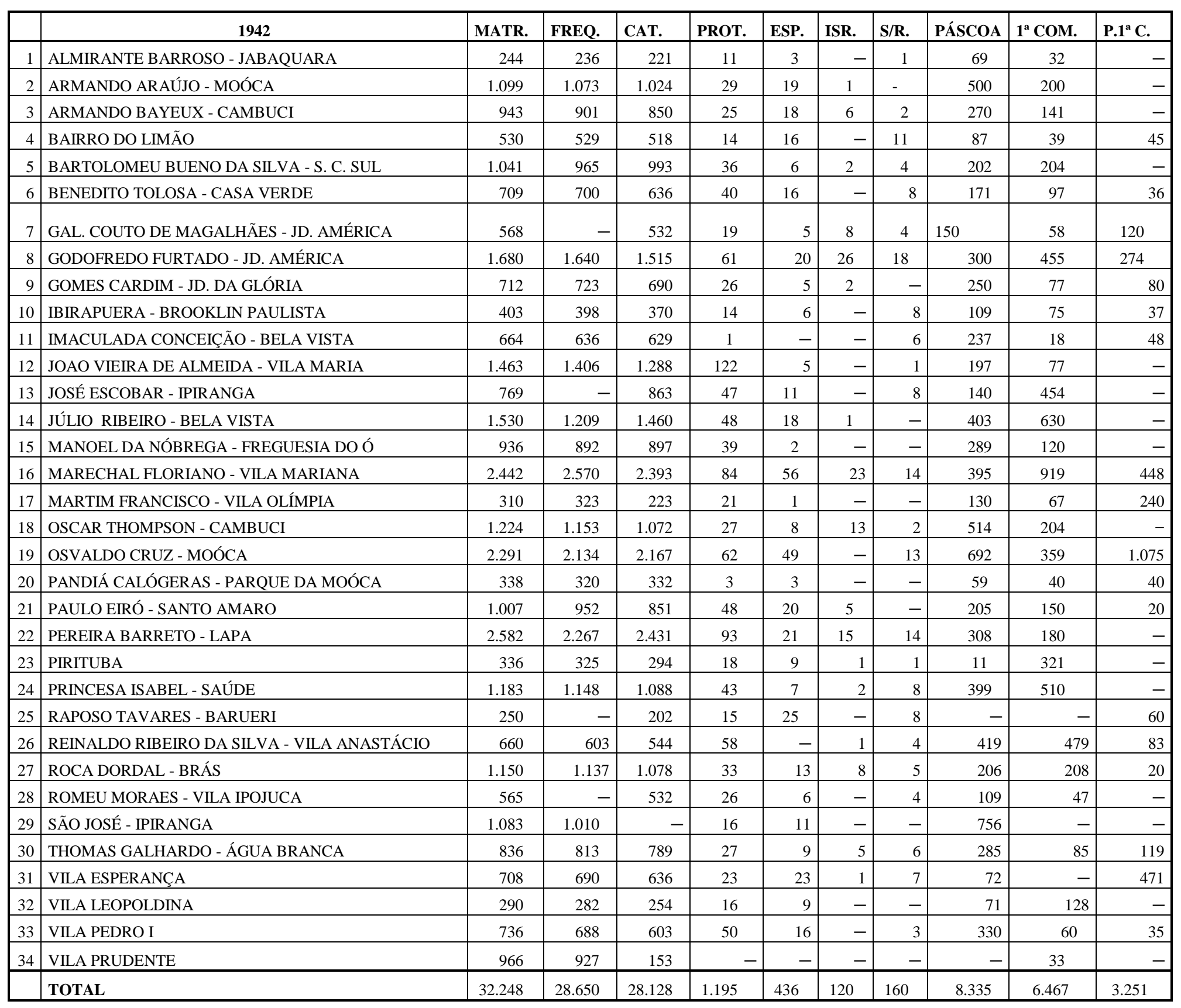




\begin{tabular}{|c|c|c|c|c|c|c|c|c|c|c|}
\hline & 1943 & MATR. & FREQ. & CAT. & PROT. & ESP. & ISR. & S/ R. & PASCOA & $1^{\mathrm{a}}$ COM. \\
\hline 1 & ALMIRANTE BARROSO - JABAQUARA & 404 & 397 & 358 & 28 & 9 & - & 2 & 144 & 52 \\
\hline 2 & ARMANDO BAYEUX - CAMBUCI & 1.334 & 1.191 & 1.128 & 27 & 12 & - & 24 & 300 & 41 \\
\hline 3 & BAIRRO DO LIMÃO & 687 & 625 & 554 & 15 & 28 & - & 18 & 161 & 59 \\
\hline 4 & BARTOLOMEU BUENO DA SILVA - S.C.SUL & 1.064 & 1.018 & 939 & 50 & 9 & 14 & 6 & 167 & 227 \\
\hline 5 & GAL. COUTO DE MAGALHÃES - JD. AMÉRICA & 598 & - & 562 & 19 & 4 & 12 & - & 168 & 90 \\
\hline 6 & GODOFREDO FURTADO - JD. AMÉRICA & 1.752 & 1.698 & 1.601 & 54 & 18 & 16 & 4 & 450 & 190 \\
\hline 7 & GOMES CARDIM - JD. DA GLÓRIA & 840 & 870 & 805 & 45 & 10 & 8 & 2 & 310 & 124 \\
\hline 8 & IBIRAPUERA - BROOKLIN PAULISTA & 591 & 614 & 570 & 30 & 4 & - & 10 & 68 & 54 \\
\hline 9 & JOAO VIEIRA DE ALMEIDA - VILA MARIA & 1.608 & 1.534 & 1.399 & 104 & 29 & 1 & 1 & 173 & 193 \\
\hline 10 & JOSÉ ESCOBAR - IPIRANGA & 922 & 1.002 & 954 & 71 & 22 & - & 1 & 178 & 78 \\
\hline 11 & JÚLIO RIBEIRO - BELA VISTA & 1.279 & 1.162 & 1.102 & 37 & 18 & 1 & 1 & 398 & 113 \\
\hline 12 & MANOEL DA NÓBREGA - FREGUESIA DO Ó & 828 & 798 & 764 & 29 & 5 & - & - & 370 & 57 \\
\hline 13 & MARECHAL FLORIANO - VILA MARIANA & 2.528 & 2.427 & 2.254 & 92 & 52 & 16 & 6 & 726 & 144 \\
\hline 14 & MARTIM FRANCISCO - VILA OLÍMPIA & 336 & 395 & 376 & 19 & - & - & - & 148 & 70 \\
\hline 15 & OSCAR THOMPSON - CAMBUCI & 1.274 & 1.118 & 1.057 & 37 & 9 & 20 & 3 & 467 & 187 \\
\hline 16 & OSVALDO CRUZ - MOÓCA & 2.423 & 2.272 & 2.162 & 76 & 20 & 13 & 1 & 781 & 518 \\
\hline 17 & PANDIÁ CALÓGERAS - PARQUE DA MOÓCA & 387 & 386 & 386 & - & - & 1 & - & 74 & 57 \\
\hline 18 & PAULO EIRÓ - SANTO AMARO & 1.125 & 987 & 925 & 40 & 29 & - & - & 304 & 157 \\
\hline 19 & PEREIRA BARRETO - LAPA & 2.560 & 2.346 & 2.204 & 87 & 24 & 11 & 20 & 300 & 211 \\
\hline 20 & PRINCESA ISABEL - SAÚDE & 1.183 & 1.185 & 1.079 & 60 & 30 & 9 & 7 & 356 & 109 \\
\hline 21 & RAPOSO TAVARES - BARUERI & 247 & 247 & 219 & 20 & 8 & - & - & 125 & 25 \\
\hline 22 & REINALDO RIBEIRO DA SILVA - VL. ANASTÁCIO & 660 & 603 & 546 & 56 & - & 1 & 4 & 419 & 6 \\
\hline 23 & ROCA DORDAL - BRÁS & 1.162 & 1.085 & 1.085 & 53 & 19 & 3 & 2 & 360 & 140 \\
\hline 24 & ROMEU MORAES - VILA IPOJUCA & 604 & 590 & 557 & 23 & 6 & - & - & 400 & 206 \\
\hline 25 & SÃO JOSÉ - IPIRANGA & 1.100 & 977 & 959 & 12 & 2 & - & 4 & 733 & 167 \\
\hline 26 & THOMAS GALHARDO - ÁGUA BRANCA & 830 & 810 & 767 & 38 & 3 & 2 & - & 265 & 120 \\
\hline 27 & VILA ESPERANÇA & 772 & 772 & 712 & 21 & 28 & - & 11 & 100 & 105 \\
\hline 28 & VILA LEOPOLDINA & 286 & 317 & 284 & 17 & 6 & - & - & 138 & 11 \\
\hline 29 & VILA PRUDENTE & 1.083 & - & 85 & - & - & - & - & - & 25 \\
\hline & TOTAL & 30.467 & 27.426 & 26.393 & 1.160 & 404 & 128 & 127 & 8.583 & 3.536 \\
\hline
\end{tabular}




\begin{tabular}{|c|c|c|c|c|c|c|c|c|c|c|c|}
\hline & 1944 & MATR. & FREQ. & CAT. & PROT. & ESP. & ISR. & $\mathbf{S} / \mathbf{R}$ & PASCOA & 1․ㅡ. COM. & P. $1^{\mathrm{a}} \mathrm{C}$ \\
\hline 1 & ALMIRANTE BARROSO - JABAQUARA & 494 & 469 & 428 & 34 & 7 & - & - & 200 & 48 & - \\
\hline 2 & ARMANDO BAYEUX - CAMBUCI & 1.265 & 1.226 & 1.162 & 34 & 4 & - & 26 & 209 & 47 & - \\
\hline 3 & ARTUR ALVIM & 368 & 360 & 317 & 27 & 10 & - & 6 & 79 & 31 & - \\
\hline 4 & BAIRRO DO LIMÃO & 600 & 840 & 766 & 23 & 22 & - & - & 80 & 50 & - \\
\hline 5 & BARTOLOMEU BUENO DA SILVA - S.C.SUL & 1.099 & 1.079 & 1.020 & 43 & 13 & 1 & 2 & 143 & 157 & - \\
\hline 6 & BUSSOCABA - OSASCO & 285 & 289 & 280 & 7 & 2 & - & - & 80 & 30 & - \\
\hline 7 & CEL. PEDRO ÁLVARES - VILA CARRÃO & 878 & 894 & 850 & 24 & 20 & - & - & 250 & - & - \\
\hline 8 & GAL. COUTO DE MAGALHÃES - JD. AMÉRICA & 559 & & 523 & 24 & 3 & 1 & - & 165 & 70 & - \\
\hline 9 & GODOFREDO FURTADO - JD. AMÉRICA & 1.820 & 1.978 & 1.850 & 52 & 26 & 38 & 12 & 1.800 & 120 & - \\
\hline 10 & GOMES CARDIM - JD. DA GLÓRIA & 1.099 & 1.032 & 937 & 60 & 20 & 10 & 5 & 380 & 50 & - \\
\hline 11 & IBIRAPUERA - BROOKLIN PAULISTA & 631 & 652 & 596 & 31 & 10 & - & 15 & 73 & 95 & - \\
\hline 12 & JOAO VIEIRA DE ALMEIDA - VILA MARIA & 1.924 & 1.837 & 1.719 & 96 & 22 & - & - & 143 & 98 & - \\
\hline 13 & JOSÉ ESCOBAR - IPIRANGA & 1.208 & 1.188 & 1.069 & 64 & 15 & - & 1 & 184 & 157 & - \\
\hline 14 & JÚLIO RIBEIRO - BELA VISTA & 1.456 & 1.192 & 1.115 & 52 & 20 & 1 & - & 422 & 66 & - \\
\hline 15 & MANOEL DA NÓBREGA - FREGUESIA DO Ó & 1.459 & 1.426 & 1.301 & 80 & 12 & - & 33 & 310 & 109 & - \\
\hline 16 & MARECHAL BITTENCOUT - OSASCO & 820 & 816 & 788 & 10 & 3 & - & - & 748 & 159 & - \\
\hline 17 & MARECHAL FLORIANO - VILA MARIANA & 2.493 & 2.465 & 2.336 & 90 & 23 & 13 & 3 & 161 & 95 & - \\
\hline 18 & MARTIM FRANCISCO - VILA OLÍMPIA & 489 & 562 & 533 & 24 & 5 & & - & 208 & 74 & - \\
\hline 19 & OSCAR THOMPSON - CAMBUCI & 1.167 & 1.156 & 1.076 & 48 & 16 & - & 1 & 425 & 138 & \\
\hline 20 & OSVALDO CRUZ - MOÓCA & 2.370 & 2.312 & 2.194 & 55 & 34 & 29 & 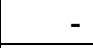 & 750 & 452 & - \\
\hline 21 & PANDIÁ CALÓGERAS - PARQUE DA MOÓCA & 354 & 343 & 334 & 3 & 3 & & 3 & 78 & 73 & \\
\hline 22 & PAULO EIRÓ - SANTO AMARO & 1.251 & 1.124 & 1.159 & 55 & 27 & - & 6 & 464 & 155 & 184 \\
\hline 23 & PEREIRA BARRETO - LAPA & 1.251 & 2.603 & 2.420 & 133 & 27 & 15 & 8 & 448 & 220 & - \\
\hline 24 & PRINCESA ISABEL - SAÚDE & 1.561 & 1.598 & 1.469 & 80 & 27 & 19 & 3 & 373 & 122 & - \\
\hline 25 & $\begin{array}{l}\text { REINALDO RIBEIRO DA SILVA - VL. } \\
\text { ANASTÁCIO }\end{array}$ & 586 & 831 & 740 & 78 & 6 & 2 & 5 & 402 & 25 & \\
\hline 26 & ROCA DORDAL - BRÁS & 1.193 & 1.098 & 1.098 & 68 & 27 & - & 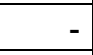 & 300 & 200 & \\
\hline 27 & ROMEU MORAES - VILA IPOJUCA & 856 & 829 & 786 & 30 & 11 & - & 2 & 190 & 118 & \\
\hline 28 & SÃO JOSÉ - IPIRANGA & 973 & 907 & 888 & 16 & 3 & - & -1 & 637 & 148 & \\
\hline 29 & THOMAS GALHARDO - ÁGUA BRANCA & 869 & 847 & 814 & 24 & 2 & 3 & 3 & 246 & 5 & \\
\hline 30 & VILA ESPERANÇA & 780 & 810 & 749 & 25 & 29 & - & 7 & 112 & 100 & \\
\hline & TOTAL & 32.158 & 32.763 & 31.317 & 1.390 & 449 & 132 & 141 & 10.060 & 3.207 & 184 \\
\hline
\end{tabular}




\begin{tabular}{|c|c|c|c|c|c|c|c|c|c|c|}
\hline & 1945 & MATR. & FREQ. & CAT. & PROT. & ESP. & ISR. & S/ R. & PASCOA & $1^{\text {a }}$ COM. \\
\hline 1 & ALMIRANTE BARROSO - JABAQUARA & 527 & 499 & 463 & 34 & 2 & - & - & 218 & 105 \\
\hline 2 & ARMANDO BAYEUX - CAMBUCI & 1.314 & 1.380 & 1.321 & 40 & 11 & - & 8 & 130 & 98 \\
\hline 3 & BARTOLOMEU BUENO DA SILVA - S. C. SUL & 1.113 & 1.101 & 1.037 & 38 & 18 & 1 & & 285 & 186 \\
\hline 4 & BUSSOCABA - OSASCO & 338 & 372 & 332 & 18 & 8 & - & & 90 & 137 \\
\hline 5 & CEL. PEDRO ÁLVARES - VILA CARRÃO & 1.073 & 1.030 & 929 & 73 & 55 & 6 & 8 & 120 & 203 \\
\hline 6 & GAL. COUTO DE MAGALHÃES - JD. AMÉRICA & 545 & & 505 & 24 & 7 & 3 & 1 & 165 & 70 \\
\hline 7 & GODOFREDO FURTADO - JD. AMÉRICA & 1.682 & 1.608 & 1.488 & 70 & 23 & 21 & 6 & 215 & 120 \\
\hline 8 & GOMES CARDIM - JD. DA GLÓRIA & 1.191 & 1.152 & 1.069 & 55 & 15 & 8 & 5 & 580 & 270 \\
\hline 9 & IBIRAPUERA - BROOKLIN PAULISTA & 648 & 657 & 586 & 57 & 8 & - & 6 & 112 & 162 \\
\hline 10 & JOAO VIEIRA DE ALMEIDA - VILA MARIA & 1.931 & 1.882 & 1.753 & 103 & 24 & - & 2 & 118 & 149 \\
\hline 11 & JOSÉ ESCOBAR - IPIRANGA & 1.570 & 1.180 & 1.093 & 67 & 20 & - & - & 147 & 128 \\
\hline 12 & JÚLIO RIBEIRO - BELA VISTA & 1.477 & 1.187 & 1.102 & 50 & 31 & 1 & 1 & 404 & 172 \\
\hline 13 & MANOEL DA NÓBREGA - FREGUESIA DO Ó & 1.494 & 1.418 & 1.332 & 49 & 12 & - & 25 & 226 & 149 \\
\hline 14 & MARECHAL BITTENCOUT - OSASCO & 861 & 825 & 752 & 72 & 20 & - & - & 295 & 163 \\
\hline 15 & MARECHAL FLORIANO - VILA MARIANA & 2.428 & 2.327 & 2.159 & 110 & 47 & 11 & - & 187 & 250 \\
\hline 16 & MARTIM FRANCISCO - VILA OLÍMPIA & 553 & 539 & 504 & 32 & 3 & 166 & & 166 & 87 \\
\hline 17 & OSCAR THOMPSON - CAMBUCI & 1.203 & 1.133 & 1.059 & 36 & 17 & 21 & - & 393 & \\
\hline 18 & OSVALDO CRUZ - MOÓCA & 2.427 & 2.354 & 2.253 & 69 & 18 & 1 & 13 & 633 & 331 \\
\hline 19 & PANDIÁ CALÓGERAS - PARQUE DA MOÓCA & 348 & 323 & 314 & 6 & 3 & 1 & - & 86 & 70 \\
\hline 20 & PAULO EIRÓ - SANTO AMARO & 1.200 & 1.163 & 1.057 & 69 & 30 & - & 2 & 174 & 71 \\
\hline 21 & PEREIRA BARRETO - LAPA & 2.451 & 2.369 & 2.212 & 110 & 25 & 13 & 9 & 400 & 250 \\
\hline 22 & PRINCESA ISABEL - SAÚDE & 1.731 & 1.687 & 1.544 & 77 & 39 & 1 & 26 & 412 & 152 \\
\hline 23 & $\begin{array}{l}\text { REINALDO RIBEIRO DA SILVA - VI. } \\
\text { ANASTÁCIO }\end{array}$ & & 782 & 643 & 68 & 12 & 15 & - & 122 & 34 \\
\hline 24 & ROCA DORDAL - BRÁS & 1.158 & 1.061 & 1.061 & 65 & 23 & - & 2 & 300 & 200 \\
\hline 25 & ROMEU MORAES - VILA IPOJUCA & 865 & 852 & 795 & - & 5 & - & 2 & 259 & 82 \\
\hline 26 & THOMAS GALHARDO - ÁGUA BRANCA & 940 & 851 & 809 & 30 & 6 & 3 & 3 & 207 & 137 \\
\hline 27 & VILA ESPERANÇA & 998 & 920 & 845 & 35 & 32 & - & 6 & 84 & 73 \\
\hline & TOTAL & 32.066 & 30.652 & 29.017 & 1.457 & 514 & 272 & 125 & 6.528 & 3.849 \\
\hline
\end{tabular}




\section{Considerações finais}

A análise da aplicação do Ensino Religioso nos anos 1930 a 1945 faz perceber que era parte de um grande plano para fortalecimento da Igreja Católica. O projeto católico foi mundial e começou desde o século XIX, com os papas Pio IX e Leão XIII, numa tentativa de confronto com os ideais socialistas e o secularismo. O modelo de Ensino Religioso ensinado nas escolas do período está inserido neste contexto, tanto no plano interno brasileiro, quanto no plano externo. A importância da formação espiritual de crianças e jovens, o ensino da ética e da moral são fundamentais. Porém, o que foi ensinado na época não foi o que pode ser considerado ideal. Teve mais o caráter de doutrinação.

Inicialmente, procurou-se observar setores conservadores e progressistas dentro da Igreja Católica, mas aquele momento viu-se uma instituição bastante fechada e relutante em se aproximar das questões sociais e de dialogar com outras confissões religiosas. Grande parte dos religiosos parecia ainda querer a busca pelo eterno retorno à Idade Média, quando o catolicismo tinha domínio quase total sobre a população na Europa, sobre as mentes e também sobre as propriedades. Havia, no entanto, setores mais radicais, com o Padre Leonel Franca, o Cônego Antonio de Castro Mayer e grupos mais serenos liderados pelo Cardeal Dom Sebastião Leme. Aos poucos, alguns membros do clero e também dos leigos, foram mudando sua visão, bastante influenciados pelas doutrinas humanistas de Jacques Maritain, principalmente, como o padre Helder Câmara e Alceu Amoroso Lima, o Tristão de Athayde.

Todo o contexto da época é importante para entender cada passo dado pelos católicos. O mundo estava envolvido em regimes totalitários, em que havia controle da população por parte dos políticos. O Brasil também vivia um período autoritário, com o Estado Novo (1937-1945), no qual a Igreja Católica e governo Vargas viviam relação de apoio mútuo. As negociações foram muito íntimas e envolveram desde a inauguração do Cristo Redentor, em 1931 até a aprovação das medidas estipuladas pela Igreja. 
As escolas públicas foram expandidas durante os anos 1930 e 1940, em parte devido à obrigatoriedade do ensino primário estipulada na Constituição de 1934. Foi muito interessante estudar a prática do Ensino Religioso nessas instituições, pois oficialmente a educação era laica e existiam alunos de outras confissões religiosas, como protestantes, espíritas e israelitas. O número de protestantes era significativo para a época. Houve, então a tentativa de influenciar esses estudantes com a doutrina católica. Eles eram incentivados a participarem das missas e a fazerem Primeira Comunhão e as celebrações da Páscoa. Os dados sobre conversões, apesar de não serem expressivos, dão ideia de estímulo a esse tipo de prática, conforme visto no capítulo 4. O Ensino Religioso foi, portanto, uma parte do processo de fortalecimento católico, apoiado pela Ação Católica e com participação da sociedade leiga. 


\section{BIBLIOGRAFIA}

ALMEIDA, Alceste Pinheiro de. O cardeal Arcoverde e a reorganização eclesiástica - Tese São Paulo, 2003.

ALMEIDA, José Maria Gouvêa de; MOURA, Sérgio Lobo de. A Igreja na Primeira República. In: In: FAUSTO, Boris. História da Civilização Brasileira: O Brasil Republicano. Tomo III, volume 2: Sociedade e Instituições. Rio de Janeiro: Bertrand Brasil, 1997.

ARAÚJO, José Carlos Sousa. Igreja Católica no Brasil: um estudo de mentalidade ideológica. São Paulo: Edições Paulinas, 1986.

ARNS, Paulo Evaristo. Liberdade de ensino. Petrópolis: Vozes, 1960.

ARNS, Paulo Evaristo. O Evangelho: Incomoda? Inquieta? Interessa? Sínodo da evangelização. São Paulo: Edições Loyola, 1975.

ARNS, Paulo Evaristo. Por que escolas católicas? Petrópolis: Vozes, 1963.

ARROCHELLAS, Maria Helena (org.). A lgreja e o exercício do poder. Rio de Janeiro: ISER, cadernos do ISER n.․ 26, 1992.

AZEVEDO, Fernando de. A Cultura brasileira. $6^{\underline{a}}$ ed. Rio de Janeiro/Brasília: Editora UFRJ-UNB, 1996.

AZZI, Riolando. História da educação católica no Brasil: contribuição dos Irmãos Maristas / os primórdios da obra de Champagnat no Brasil. 3v. São Paulo: Simar, 1997.

AZZI, Riolando. Presença da Igreja Católica na Sociedade Brasileira 19211979. Rio de Janeiro: Tempo e Presença (Cadernos do ISER 13), 1981.

AZZI, Riolando. GRIJP, Klaus Van Der. História da Igreja no Brasil: terceira época. 1930-1964. Petrópolis: Vozes, 2008

BACELLAR, Carlos de Almeida Prado. Uso e mau uso dos arquivos. In: PINSKY, Carla Bassanezi (org.) Fontes Históricas. São Paulo: Contexto, 2006.

BALDIN, Marco Antonio. O Cardeal Leme e a construção da ordem política católica (1930-1942). Tese (Doutorado em História) Universidade Estadual Paulista. Franca:[s.n.], 2014

BARROS, Roque Maciel Spencer de. A llustração Brasileira e a ideia de universidade. São Paulo: FFLCH-USP, 1959.

BASTOS, Pedro Paulo Zahluth. FONSECA, Pedro Cezar Dutra. A Era Vargas: desenvolvimentismo, economia e sociedade. São Paulo: Editora da UNESP, 2012. 
BEISIEGEL, Celso de Rui. Educação e Sociedade no Brasil após 1930. In.: FAUSTO, Boris. História da Civilização Brasileira: O Brasil Republicano: Economia e cultura - 1930 - 1964. Tomo II, v. 4ํ. São Paulo: Difel, 1984.

BEOZZO, José Oscar. (coord.) História da Igreja no Brasil. Petrópolis: Vozes, 1980.

BEOZZO, José Oscar. A Igreja entre a Revolução de 1930, o Estado Novo e a Redemocratização. In: FAUSTO, Boris. História da Civilização Brasileira: O Brasil Republicano: Economia e cultura - 1930 - 1964. Tomo II, v. 4․ São Paulo: Difel, 1997.

BEOZZO, José Oscar. Cristãos na Universidade e na Política: história da JUC e da AP. Petrópolis: Vozes, 1984.

BLAINEY, Geoffrey. Uma breve história do Cristianismo. São Paulo: Editora Fundamento Educacional Ltda., 2012.

BOURDIEU, Pierre. A economia das trocas simbólicas. São Paulo: Perspectiva, 1992.

BOURDIEU, Pierre. Escritos de educação. Maria Alice Nogueira e Afrânio Catani (orgs.) 16a ed. Petrópolis: Vozes, 2015.

BRUNEAU, Thomas Charles. O catolicismo brasileiro em época de transição. São Paulo: Edições Loyola, 1974.

CALDEIRA, Rodrigo Coppe. Em defesa da Ação Católica: Plínio Corrêa de Oliveira, um baluarte da tradição. In: Revista Brasileira de História das Religiões, ANPUH, ano VI, no 16, maio 2013.

CAMARGO, Monsenhor Paulo Florêncio da Silveira. A Igreja Na História de São Paulo. v. 7. São Paulo: Instituto Paulista de História e Arte Religiosa, 1953.

CAMARGO, Monsenhor Paulo Florêncio da Silveira. História Eclesiástica do Brasil. Petrópolis: Vozes, 1955.

CAMPOS, Névio de. Intelectuais e Igreja Católica no Paraná: 1926-1938. Ponta Grossa: Editora UEPG, 2010.

CARDOSO, Ciro F. S. \& VAINFAS, Ronaldo (orgs.) Domínios da História. Rio de Janeiro: Campus. 1997.

CARNEIRO, Maria Luiza Tucci. O antissemitismo na Era Vargas: fantasmas de uma geração 1930-1945. São Paulo: Brasiliense, 1988.

CARONE, Edgard. A República Nova. 1930-1937. São Paulo: DIFEL, 1982.

CARONE, Edgard. A Terceira República.1937-1945. São Paulo: DIFEL, 1982. 
CARVALHO, Carlos Henrique de e NETO, Wenceslau Gonçalves. (orgs.) Estado, Igreja e Educação: o mundo ibero-americano nos séculos XIX e XX. Campinas: Alínea, 2010.

CARVALHO, José Murilo de. Os Bestializados: o Rio de Janeiro e a República que não foi. São Paulo: Companhia das Letras, 1987.

CARVALHO, Marta Maria Chagas de. Molde Nacional e fôrma cívica: higiene, moral e trabalho no projeto da Associação Brasileira de Educação (19241931). Bragança Paulista: EDUSF, 1998.

CATANI, Denice Bárbara. Educadores a meia-luz: um estudo sobre a revista de ensino da Associação Beneficente do Professorado Público de São Paulo. 1989. 392f. Tese (Doutorado em Educação) - Faculdade de Educação da Universidade de São Paulo, São Paulo.

COSTA, Marcelo Timotheo da. Um itinerário do século: mudança, disciplina e ação em Alceu Amoroso Lima. Rio de Janeiro: Editora PUC-Rio; São Paulo: Loyola, 2006.

CURRÍ́CULO do Estado de São Paulo: Ciências Humanas e suas Tecnologias / Secretaria da Educação. Coordenação Geral: Maria Inês Fini. Coordenação de área: Paulo Miceli. São Paulo: SE, 2011.

CURY, Carlos Roberto Jamil. Alceu Amoroso Lima. Coleção Educadores. Recife: Fundação Joaquim Nabuco, Editora Massangana, 2010.

CURY, Carlos Roberto Jamil. Ideologia e Educação Brasileira: católicos e liberais. São Paulo: Cortez, 1984.

DANTAS, Arruda. D. Duarte Leopoldo. São Paulo: Sociedade Impressora Pannartz, 1974.

DE LORENZO, Helena Carvalho; COSTA, Wilma Peres. (orgs.) A década de 1920 e as origens do Brasil Moderno. São Paulo: UNESP, 1997.

DE SANCTIS, Frei Antonio. Encíclicas e documentos sociais: da "Rerum Novarum" à "Octagésima Advensis". São Paulo: Edições LTR, 1972.

DIAS, Romualdo. Imagens de ordem: a doutrina católica sobre autoridade no Brasil (1922-1933). São Paulo: Editora da UNESP, 1996.

DUARTE, Adriano Luiz. Moralidade pública e cidadania: a educação nos anos 30 e 40. In: Educação \& Sociedade, ano XXI, № 73, dezembro/00.

DURKHEIM, Émile. As Formas Elementares de Vida Religiosa (o sistema totêmico na Austrália). Tradução: Joaquim Pereira Neto. São Paulo: Paulus, 2008.

FARIA FILHO, Luciano Mendes de. (org.) Pensadores sociais e História da Educação. Belo Horizonte: Autêntica Editora, 2011. 
FARIA FILHO, Luciano Mendes de; LOPES, Eliane Marta Santos Teixeira; VEIGA, Cynthia Greive (Orgs.). 500 anos de educação no Brasil. Belo Horizonte: Autêntica, 2003.

FAUSTO, Bóris. "A Revolução de 1930". In.: MOTA, Carlos Guilherme (org.) Brasil em Perspectiva. São Paulo; Rio de Janeiro: DIFEL, 1978.

FAUSTO, Boris. Getúlio Vargas: o poder e o sorriso. São Paulo: Companhia das Letras, 2008.

FAUSTO, Boris. História do Brasil. 14ª ed. São Paulo: EDUSP, 2012.

FAUSTO, Boris. Revolução de 1930: historiografia e história. 16ª ed. São Paulo: Companhia das Letras, 2010.

FERNESSOLE, Pierre. Pio XII e na educação da juventude. São Paulo: Paulinas, 1966.

FERREIRA, Antonio Celso. A epopeia bandeirante: letrados, instituições, invenção histórica (1870-1940). São Paulo: UNESP, 2002.

FERREIRA, Jorge. DELGADO, Lucília de Almeida Neves. O Brasil Republicano. v. 2: O tempo do nacional-estatismo: do início da década de 1930 ao apogeu do Estado Novo. Rio de Janeiro: Civilização Brasileira, 2011.

FREITAG, Bárbara. Escola, Estado e Sociedade. São Paulo: EDART, 1978.

GHIRALDELLI JR., Paulo. História da Educação no Brasil. (1930-1973) 23ªed. Petrópolis: Vozes, 1999.

GOMES, Angela de Castro (org.). Capanema: o ministro e seu ministério. Rio de Janeiro: FGV, 2000.

HANSEN, Patrícia Santos. Território em disputa: a escola na luta entre o republicanismo e a Igreja em Portugal (séculos XIX e XX). Revista Brasileira de História. São Paulo, v. 32, № 64, p. 231-250 - 2012.

HOBSBAWN, Eric J. Nações e Nacionalismo desde 1780. Tradução: Maria Célia Paoli, Anna Maria Quirino. Rio de Janeiro: Paz e Terra, 1990.

HOBSBAWN, Eric J. Era dos Extremos: o breve século XX: 1914-1991. São Paulo: Companhia das Letras, 1995.

HOORNAERT, Eduardo. História da Igreja no Brasil: ensaio de interpretação a partir do povo. Petrópolis: Vozes, 1992.

JUNQUEIRA, Sérgio Rogério Azevedo. O processo de escolarização do Ensino Religioso no Brasil. 1. ed. Petrópolis: Vozes, 2002.

JUNQUEIRA, Sérgio Rogério Azevedo (org.). Ensino Religioso no Brasil. Florianópolis: Insular, 2015.

KERTZER, David I. The Pope and Mussolini: the secret history of Pius XI and the rise of Fascism in Europe. New York: Random House, 2014. 
LENHARO, Alcir. Sacralização da política. Campinas: Papirus, 1989.

LIMA, Alceu Amoroso. Cartas do Pai: de Alceu Amoroso Lima para sua filha Madre Maria Tereza. São Paulo: Instituto Moreira Salles, 2004.

LOPES, Eliane Marta Teixeira; FARIA FILHO, Luciano Mendes de. (orgs.) Pensdores Sociais e História da Educação. v.2. Belo Horizonte: Autêntica Editora, 2012.

LOPES, Sonia de Castro; CHAVES, Miriam Waidenfeld. (orgs.) A História da Educação em debate: estudos comparados, profissão docente, infância, família e Igreja. Rio de Janeiro: Mauad X: FAPERJ, 2012.

LOVE, Joseph. A Locomotiva. São Paulo na Federação Brasileira 1889-1937. Rio de Janeiro: Paz e Terra, 1982.

LUCA, Tânia Regina de. Fontes impressas: História dos, nos e por meio dos periódicos. In: PINSKY, Carla Bassanezi (org.). Fontes Históricas. São Paulo: Contexto, 2005.

MAINWARING, Scott. Igreja Católica e política no Brasil (1916-1985). Tradução: Heloisa Braz de Oliveira Prieto. São Paulo: Brasiliense, 2004.

MANIFESTO dos Pioneiros da Educação Nova. 1932. Revista HISTEDBR Online, Campinas, n. especial, p.188-204, ago. 2006 - ISSN: 1676-2584. Acesso em 28/11/2011.

MANOEL, Ivan Aparecido. A Ação Católica Brasileira: notas para um Estudo. In.: Acta Scientiarum. Maringá - UEM, v. 21, o1, págs. 207-215. 1999.

MARCÍLIO, Maria Luiza. História da escola em São Paulo e no Brasil. São Paulo: Imprensa Oficial do Estado de São Paulo: Instituto Fernand Braudel, 2005.

MARITAIN, Jacques. Humanismo integral: uma visão nova da ordem cristã. São Paulo: Companhia Editora Nacional, 1965.

MARITAIN, Jacques. LIMA, Alceu Amoroso. O Homem e o Estado. Rio de Janeiro: Agir, 1966.

MARITAIN, Jacques. Rumos da educação. Rio de Janeiro: Agir, 1966.

MARTINS, Luís Arrobas. Educação brasileira e colégios de padres. São Paulo: Herder, 1966.

MARTINS, Patrícia Carla de Melo. Prática e representações femininas do Catolicismo a cultura letrada: O modelo civilizatório europeu sobre o Brasil, no início do século XX. Jundiaí - SP: Paco, 2011

MATA, Sérgio da. História \& Religião. Belo Horizonte: Autêntica, 2010.

MATOS, Henrique Cristiano José. Nossa História: 500 anos de presença da Igreja Católica no Brasil. Tomo 3: Período republicano e atualidade. $2^{\underline{a}}$ edição. São Paulo: Paulinas, 2011. 
MELLO, Maria Lucia Cardozo de. Irmãos maristas em São Paulo : 1899-1935 - São Paulo, 1996.

MICELI, Sérgio. A elite eclesiástica brasileira: 1890-1930. São Paulo: Companhia das Letras, 2009.

MICELI, Sérgio. Intelectuais à brasileira. São Paulo: Companhia das Letras, 2001.

MONARCHA, Carlos. Escola Normal da Praça. Campinas: Editora da Unicamp, 1999.

MORAES, M. Célia M. de. Educação e política no pensamento de Francisco Campos. Rio de Janeiro, 1990. Tese(Doutorado) - PUC-RJ.

NAGLE, Jorge. Educação e Sociedade na Primeira República. São Paulo: EPU/EDUSP, 1974.

NASCIMENTO, Benedicto Heloiz. A ordem nacionalista brasileira: 0 nacionalismo como política de desenvolvimento durante o Governo Vargas, 1930-1945. São Paulo: Humanitas/ FFLCH/USP: Instituto de Estudos Brasileiros/ USP, 2002.

NETO, Lira. Getúlio: do Governo Provisório à ditadura do Estado Novo (19301945). São Paulo: Companhia das Letras, 2013.

NUNES, Clarice. A poesia da ação. Bragança Paulista: EDUSF, 2000.

OLIVEIRA, Terezinha. (org.). Religiosidade e Educação na História. Maringá: EDUEM, 2010.

PILETTI, Nelson. História da Educação no Brasil. São Paulo: Ática, 1997.

PINHEIRO, Ana Regina. Escola Caetano de Campos: Escola Paulista, Escola Vanguardeira. Tese de Doutorado. Universidade Estadual de Campinas, Faculdade de Educação, 2008.

PINHEIRO, Ana Regina. Instrução do povo sob a proteção do catolicismo militância docente e a expansão da escolarização em São Paulo. In: Revista Brasileira de História da Educação. Maringá-PR, V. 15, no 2(38), p. 193-219, mai./ago. 2015.

PINHEIRO, Ana Regina. Formação de almas e inteligências: educadores católicos e a escola de formação de professores. In: Revista Brasileira de História das Religiões. ANPUH, Maringá (PR) v. V, Edição Especial, jan/2013.

PINSKY, Jaime. "O Brasil nas Relações Internacionais". MOTA, Carlos Guilherme (org.) Brasil em Perspectiva. São Paulo; Rio de Janeiro: DIFEL, 1978.

PORTA, Paula. DUARTE, Adriano. História da Cidade de São Paulo: a cidade na primeira metade do século XX (1890-1954) v. 3. São Paulo: Paz e Terra, 2004. 
RÉMOND, René. (org.) Por uma História Política. Tradução: Dora Rocha. Rio de Janeiro: Editora FGV, 2003.

RIBEIRO, José Augusto. A Era Vargas. Rio de Janeiro: Casa Jorge, 2002.

RIBEIRO, Maria Luíza S. História da Educação Brasileira: a organização escolar. São Paulo: Editora Moraes, 1981.

RODRIGUES, Anna Maria Moog. A Igreja na República. Brasília: Editora da UNB, 1981.

ROMANELLI, Otaíza de Oliveira. História da Educação no Brasil (1930-1973). Petrópolis: Vozes,1983.

ROSA, Lilian Rodrigues de Oliveira. A Igreja Católica Apostólica Romana e o Estado brasileiro: estratégias de inserção política da Santa Sé no Brasil entre 1920 e 1937. 2011. 278f. Tese (Doutorado em História) - Faculdade de Ciências Humanas e Sociais, Universidade Estadual Paulista "Júlio de Mesquita Filho", Franca, 2011.

ROUSSEAU, Jean-Jacques. Carta a Christophe de Beaumont e outros escritos sobre a Religião e a Moral. Organização, tradução e apresentação José Oscar de Almeida Marques. São Paulo: Estação Liberdade, 2005.

SANTOS, Jacinto Donizeti dos. História e memória do Santo Alberto: ideias e práticas pedagógicas em tempos de transição (1930-1950). São Paulo, 1997. Dissertação (Mestrado em Educação) - FE-USP.

SARANYANA, Josep-Ignasi. Cem Anos de Teologia na América Latina (18992001), Coleção Quinta Conferência História; Editora Paulinas/Paulus, 2005.

SAVIANI, Dermeval. Histórias das ideias pedagógicas no Brasil. Campinas; Autores Associados, 2010.

SCHWARTZMAN, Simon; BONEMY, Helena Maria Bousquet; COSTA, Vanda Maria Ribeiro. Tempos de Capanema. Rio de Janeiro: Paz e Terra; São Paulo: EDUSP, 1984.

SEVCENKO, Nicolau (org.) NOVAIS, Fernando A. (coord). História da Vida Privada no Brasil. República: da belle-époque à era do rádio. São Paulo: Companhia das Letras, 2010.

SKIDMORE, Thomas E. Brasil: de Getúlio a Castelo. (1930-1964) São Paulo: Companhia das Letras, 2010.

SODRÉ, Nelson Werneck. História da Imprensa no Brasil. Rio de Janeiro: Mauad, 1999.

SOLA, Lourdes. "O Golpe de 37 e o Estado Novo". In.: MOTA, Carlos Guilherme (org.) Brasil em Perspectiva. São Paulo; Rio de Janeiro: DIFEL, 1978. 
SOUZA, Maria do Carmo Campello de. Estados e Partidos Políticos no Brasil. 1930-1964. São Paulo: Alfa-Omega, 1990.

TEIXEIRA, Anísio. Educação é um direito. São Paulo: Editora Nacional, 1968.

TEIXEIRA, Anísio. Educação não é privilégio. Rio de Janeiro: José Olympio, 1957.

TODARO, Margareth P. Pastors, prophets and politicians: a study of the Brazilian Catholic Church - 1916-1945. Dissertação de Ph.D. Nova York, Universidade de Columbia, 1971.

VAGO, T. M. et.al. (orgs.) Intelectuais e escola pública no Brasil. Séculos XIX e XX. Belo Horizonte: Mazza Edições, 2009.

VIANA FILHO, Luís. Anísio Teixeira: a polêmica da educação. São Paulo: UNESP, 2008.

VIDAL, Diana Gonçalves. (org.) Na batalha da educação: correspondência entre Anísio Teixeira e Fernando de Azevedo (1929-1971). Bragança Paulista: EDUSF, 2000.

VIDAL, Diana Gonçalves; CARDOSO, Maria Cecília Ferraz de Castro. Conversa de educadores: Catálogo analítico da correspondência entre Abgar Renault e Fernando de Azevedo. Cadernos do IEB. São Paulo: IEB-USP, 1999.

VIEIRA, Dilermando Ramos. História do Catolicismo no Brasil. Volume 2: 1889-1945. Aparecida, SP: Santuário, 2016.

VILHENA, Maria Angela. PASSOS, João Décio. AUGUSTO, Adailton Maciel. $A$ Igreja de São Paulo: presença católica na história da cidade. São Paulo: Paulinas, 2005.

WERNET, Augustin. A Igreja paulista no século XIX. São Paulo: Ática, 1987.

WILLAIME, Jean-Paul. Sociologia das Religiões. Tradução: Lineimar Pereira Martins. São Paulo: Editora da UNESP, 2012.

WIRTH, John D. A política do desenvolvimento na Era de Vargas. Rio de Janeiro: Editora da FGV, 1973. 